TSP

\title{
Dinâmica populacional de pequenos mamíferos no Planalto Atlântico Paulista
}
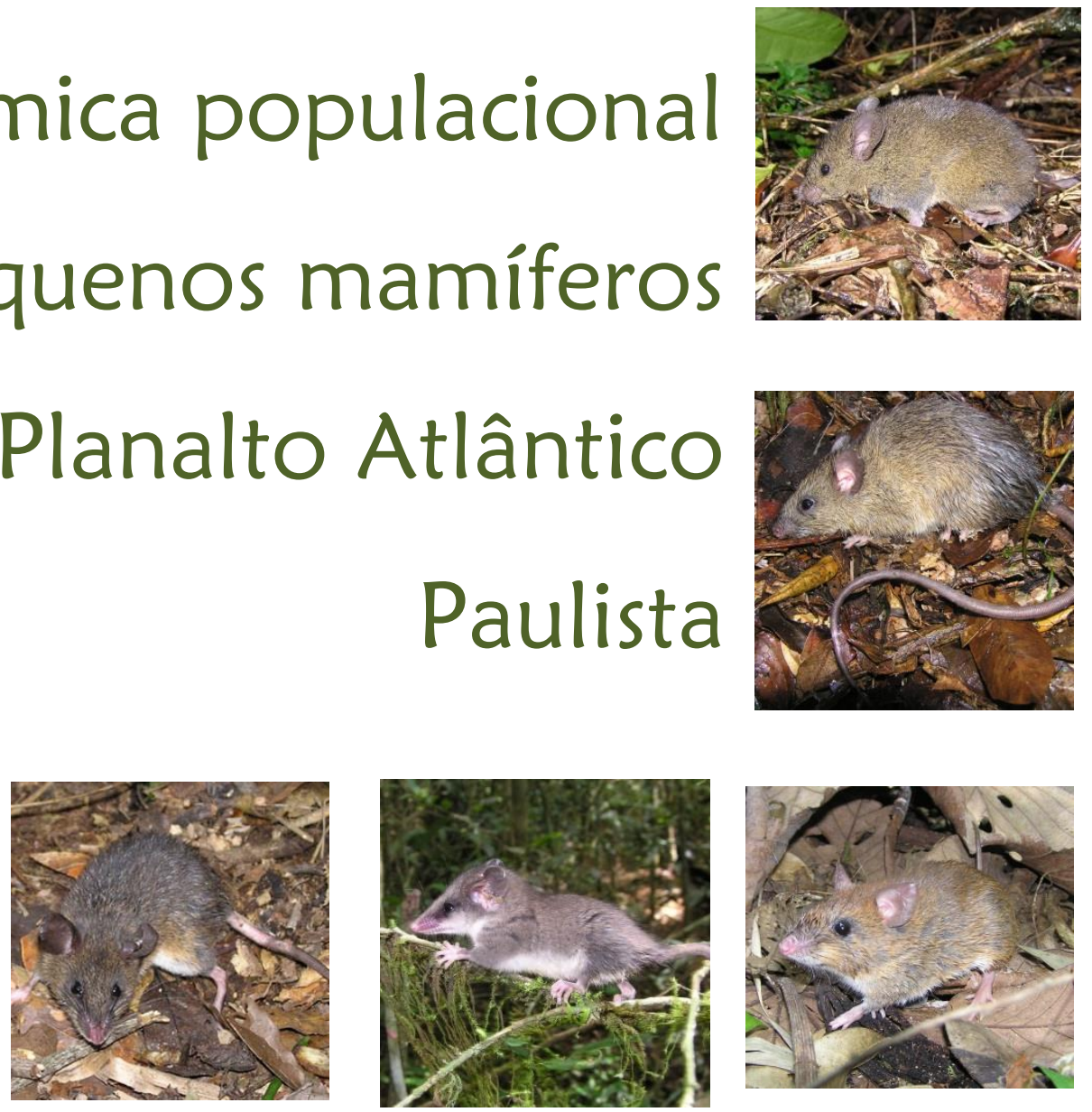

Camila dos Santos de Barros

2013 


\section{Dinâmica populacional de pequenos mamíferos no Planalto Atlântico Paulista}

\section{Small mammal population dynamics at the Atlantic Plateau of São Paulo}

Camila dos Santos de Barros

Orientadora: Renata Pardini

Co-orientador: Thomas Püttker

Tese apresentada ao Instituto de Biociências da Universidade de São Paulo, para a obtenção de Título de Doutor em Ciências, na Área de Ecologia.

São Paulo 
Barros, C.S.

Dinâmica populacional de pequenos mamíferos no Planalto Atlântico Paulista

$\mathrm{iii}+84 \mathrm{pp}$.

Tese (Doutorado) - Instituto de Biociências da Universidade de São Paulo. Departamento de Ecologia.

1. Demografia 2. Reprodução 3. Sobrevivência 4.

Demandas conflitantes 5.Sazonalidade 6. Métodos de captura I. Universidade de São Paulo. Instituto de Biociências.

Departamento de Ecologia.

Comissão Julgadora:

$\operatorname{Prof}(a) \operatorname{Dr}(a)$

Prof (a) Dr(a)

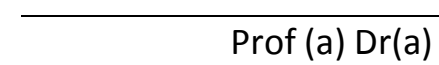

Prof (a) Dr(a)

Profa. Dra. Renata Pardini

Orientadora 
.. I'm just a child of nature 1 dan't need much to set me free I' $m$ just a child of nature I'm ane of nature's children... 


\section{Aos meus pais, Edilson e Graça.}




\section{Agradecimentos}

Agradeço ao Conselho Nacional de Desenvolvimento Científico e Tecnológico (CNPq) e à Coordenação de Aperfeiçoamento de Pessoal de Nível Superior (CAPES) pelas bolsas de doutorado e doutorado sanduíche, ao CNPq/BMBF - German Federal Ministry of Education and Research (690144/01-6), CAPES e Fundação de Amparo à Pesquisa do Estado de São Paulo (FAPESP, 05/56555-4) pelo financiamento da pesquisa de campo, ao Departamento de Ecologia da Universidade de São Paulo, Silwood Park/Imperial College London e SABESP (Companhia de Saneamento Básico do Estado de São Paulo) pela disponibilização da infraestrutura e apoio logístico para a realização deste trabalho.

À Renata Pardini, pela enorme colaboração no desenvolvimento deste trabalho, pela disposição e paciência nas revisões dos meus textos e principalmente por sempre me incentivar a buscar a excelência profissional.

Ao meu co-orientador Thomas Püttker, pelo apoio no desenvolvimento e execução do trabalho de campo e pela colaboração nos capítulos desta tese. Também pelas fotos que ilustram essa tese.

Aos professores do IB-USP, em especial, Alexandre Adalardo, Jean Paul Metzger, Paulo Inácio Prado, Paulo Guimarães e Tiago Quental pelas idéias ao longo das discussões do trabalho e pela dedicação muito especial aos alunos do PPGE. Em especial ao Paulo e ao Ale que me colocaram no mundo do R e inacreditavelmente me fizeram gostar de modelos estatísticos. À Vera Lima, secretária do PPGE, por todo auxílio, atenção e disponibilidade para sempre ajudar a resolver os nossos problemas. Aos amigos da USP, em especial à Camila Castanho pela grande ajuda com os GLMMs, Cristiane Jurinitz e Renato Lima pelas identificações.

Aos amigos queridos lá do LECP, onde tudo começou. A Fernando Fernandez e Alexandra Pires pela amizade, por terem sido fundamentais para minha formação e pelo constante apoio durante toda minha vida acadêmica.

Campo, campo e mais campo... Thaís, Camilla, Thomas e Bruno pelo companheirismo no primeiro ano de campo. Érica, Natali e Rafael foram essenciais no segundo ano de campo. E só mesmo com muita gente pra ajudar: Gustavo, Nati, Celso, Flá, Ju de Luca, Napster, Ricardo, Guima entre outros recrutados para o campo talvez a contragosto a princípio, mas certamente nenhum arrependimento no final! Obrigada, sem vocês não haveria essa tese! E lógico, aos churrascos e pizzas de Tapiraí e Morro Grande! Aos nossos mateiros, especialmente Seu Vanil e seu Adão, sem os quais estaria cavando buracos para baldes até hoje. 
Ao Tim Coulson pela oportunidade de ter feito parte do seu grupo no Imperial College of London. À Inglaterra, à Silwood e aos Silwoodians por toda motivação e por ter me dado uma nova visão sobre a ciência. A todos os amigos queridos do Brian Flowers (em especial à Catarina, Daniel, Heather, Katherine, Matthew, Melissa, Rogier, e Dani com uma pequena diferença espaçotemporal), a todos do SLAPPED (Aurélio, Ben, Isabel, Jacques, Lochran, Severin, Susanne), com carinho especial às amigas Michela, Julia, Sarah e Cris. À Sarah também pelas revisões e incentivo.

Aos amigos de São Paulo, em especial Laura, Rafa (e Bia e Ana!), amigos paulistanos com alma de cariocas sambistas! Christoph por todo apoio e por ter me dado teto desde minha chegada a São Paulo. Obrigada pelos deliciosos almoços! Paulets por sua alegria! Fabiano que "pousou" em casa e virou família.

À todos do Dicom cuja convivência diária tornou a vida muito mais feliz. Bruno, que paciência, sempre presente e ajudando com os modelos! Camilla Pagotto que com sua animação tornava o lab muito mais alegre com várias comemorações, sem falar nas comidinhas do campo! Thaís, pelo companheirismo desde que tudo começou, e até por aquelas piadinhas infames! Nati, quase te enlouqueci com as planilhas mil, obrigada pela amizade e pelas carolinas de limão! Gustavo, Camila Cassano, Enrico pelas inúmeras discussões sobre o $\mathrm{R}$ e pelos momentos divertidíssimos com vocês.

Todos meus amigos do Rio, de São Paulo e da Inglaterra foram sinceramente fundamentais para que eu chegasse ao final dessa tese e são tantos que não há como citar todos aqui. Em especial à Cris Banks, sem palavras para agradecer pelo apoio, incentivo, motivação, orientação, amizade, por tudo; à Paulinha pelo apoio sempre (que neste agradecimento eu não sabia se a colocava junto com o LECP, com a USP ou com Silwood; o fato da minha vida acadêmica ser o reflexo da sua já diz muita coisa). À Melina cuja amizade surgiu em terras cariocas nos tempos de LECP e felizmente chegou a São Paulo, junto com a Pat formamos uma família em nosso Refúgio. MM, Pat, Cá, Thá obrigada pela ouvidos que aguentaram minhas reclamações, pelo ombro amigo nos momentos difíceis e pela eterna parceria na vida.

Aos pequenos mamíferos que dão sentido à minha vida acadêmica.

E por fim aos meus pais, sem os quais nada disso teria acontecido. Somos mais do que família, somos um só. Essa tese é tanto minha quanto deles.

Muito obrigada!

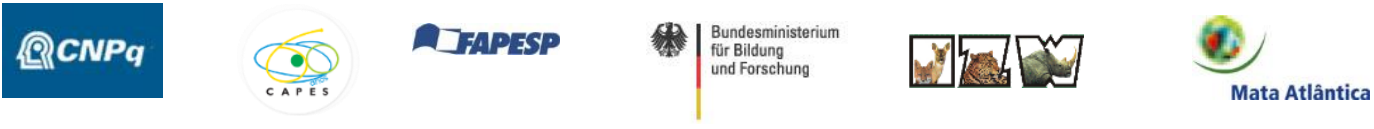




\section{Índice}

$\begin{array}{ll}\text { Resumo } & 01\end{array}$

$\begin{array}{ll}\text { Abstract } & 02\end{array}$

$\begin{array}{ll}\text { Introdução geral } & 03\end{array}$

Capítulo $1 \quad$ Effects of rainfall on population dynamics of Atlantic Forest rodents: Evidence of a trade-off between survival and reproduction 08 $\begin{array}{ll}\text { Introdução } & 09\end{array}$

Material e métodos 12

$\begin{array}{ll}\text { Resultados } & 16\end{array}$

$\begin{array}{ll}\text { Discussão } & 23\end{array}$

Capítulo 2 Timing and triggering of reproductive activity in Atlantic Forest marsupials 30

$\begin{array}{ll}\text { Introdução } & 31\end{array}$

Material e métodos 33

$\begin{array}{ll}\text { Resultados } & 37\end{array}$

$\begin{array}{ll}\text { Discussão } & 43\end{array}$

Capítulo 3 Determinants of capture-recapture success to estimate population and assemblage parameters for small mammals $\quad 50$

$\begin{array}{ll}\text { Introdução } & 51\end{array}$

Material e métodos $\quad 54$

$\begin{array}{lr}\text { Resultados } & 59\end{array}$

$\begin{array}{ll}\text { Discussão } & 65\end{array}$

$\begin{array}{ll}\text { Anexos } & 72\end{array}$

$\begin{array}{ll}\text { Considerações finais } & 74\end{array}$

$\begin{array}{ll}\text { Bibliografia } & 77\end{array}$ 


\section{RESUMO}

A compreensão da dinâmica populacional é fundamental para a conservação da biodiversidade, uma vez que as espécies são perdidas através de processos que ameaçam suas populações. Portanto, compreender como as condições ambientais determinam a dinâmica populacional é essencial, especialmente tendo em conta o cenário de mudanças climáticas. Um parâmetro populacional importante é a reprodução, que não só contribui para o tamanho da população, mas também pode afetar a condição corporal e a probabilidade de sobrevivência. Devido aos altos custos energéticos, a reprodução é freqüentemente associada com a disponibilidade de alimentos em ambientes tropicais, que por sua vez é altamente correlacionada com as condições climáticas, especialmente a precipitação. Além disso, o estudo de processos de populações ou comunidades requer dados de boa qualidade, que para vários grupos de animais depende da compreensão das interações entre os métodos de captura, condições climáticas e as características morfológicas e comportamentais de indivíduos e espécies. Através de um conjunto de dados de captura e recaptura de pequenos mamíferos em uma reserva de Mata Atlântica, compreendendo três grades de 2 ha amostrados por quase dois anos, esta tese tem como objetivos contribuir com o entendimento: (1) de como as condições ambientais afetam a dinâmica de populações, especialmente a sobrevivência e reprodução, mais especificamente, como as condições climáticas afetam a demanda conflitante (trade-off) entre a sobrevivência e reprodução e quais são as gatilhos ambientais do início da reprodução, (2) de como o tipo de armadilha, características individuais e as condições climáticas interagem para determinar o sucesso de captura, visando a definição de diretrizes de protocolos de captura eficientes para a amostragem de pequenos mamíferos. No primeiro capítulo, mostramos que a precipitação afetou negativamente as taxas de sobrevivência, positivamente a freqüência de fêmeas reprodutivas e não afetou a condição corporal, o que sugere a existência de uma demanda conflitante entre sobrevivência e reprodução em populações de roedores. No segundo capítulo, corroboramos que a reprodução de marsupiais da Mata Atlântica é sazonal e sincrônica, ocorrendo no período quente e úmido, e seu gatilho é o fotoperíodo. Também apresentamos evidências de semelparidade em marsupiais de pequeno porte. No terceiro capítulo, mostramos que a eficiência de diferentes métodos de captura foi influenciada pelas condições climáticas, dependeu da idade e do sexo dos indivíduos e foi condicionada às variáveis quantificadas (número de espécies, de indivíduos ou de recapturas). Os resultados destacam a importância de armadilhas de queda para os estudos de comunidades e a utilização conjunta de armadilhas de queda e Sherman para estudos populacionais. 


\begin{abstract}
The understanding of population dynamics is central for biodiversity conservation, since species are lost through processes that threat their populations. Understanding how environmental conditions determine population dynamics is thus essential, especially given the climate change scenario. One important population parameter is reproduction, which not only contributes to population size, but can also affect body condition and survival probability. Given its high energetic costs, reproduction is frequently associated with food availability in tropical environments, which in turn is highly correlated to weather conditions, especially rainfall. However, studying population or community processes requires good-quality data, which for several animal groups depends on understanding the interactions among trapping methods, weather conditions and morphological and behavioral characteristics of individuals and species. Through a capture-recapture dataset on small mammals in an Atlantic Forest reserve, comprising three 2 ha grids sampled for almost two years, this thesis aim at understanding: (1) how environmental conditions affect population dynamics, especially survival and reproduction; more specifically, how weather conditions affect the trade-off between survival and reproduction, and which are the environmental triggers for reproduction; (2) how the type of trap, individual traits and weather conditions interacts to determine capture success, aiming at defining guidelines for efficient protocols for small mammal sampling. In the first chapter, we show that rainfall negatively affected survival rates, positively affected the frequency of reproductive females and did not affect body condition, suggesting the existence of a trade-off between survival and reproduction in rodent populations. In the second chapter, we corroborated that reproduction of Atlantic Forest marsupials is seasonal and synchronous, occurring in the warm-wet season, and triggered by photoperiod cues. We also bring evidence for semelparity in small-sized marsupials. In the third chapter, we show that the efficiency of different trap methods was influenced by weather condition, depended on the age and sex of individuals, and was contingent on the quantified variables (number of species, of individuals or of recaptures). Results highlight the importance of Pitfalls for community studies and the joint use of Pitfall and Sherman traps for population studies.
\end{abstract}




\section{Introdução geral}

Estudos de dinâmica populacional buscam compreender como e em resposta a quais fatores externos (e.g. precipitação, disponibilidade de recursos alimentares) flutuam os parâmetros populacionais, tais como tamanho da população, taxas de sobrevivência e recrutamento, entre outros (Lima et al 2001a, 2001b, Williams et al 2002, Oli \& Dobson 2003). É alta a relevância de estudos de dinâmica de populações para a avaliação do risco de extinção das populações e, conseqüentemente, para o delineamento de medidas de manejo e conservação eficazes (Baguette \& Schtickzelle 2003), especialmente diante do cenário de mudanças climáticas que podem afetar a qualidade e sazonalidade dos habitats (Karl \& Trenberth 2003). A conservação de paisagens naturais é baseada principalmente na manutenção da biodiversidade (Myers et al 2000, Hunter et al 2007, Miller et al 2009). Contudo, a perda de biodiversidade se dá através da extinção de espécies, a qual ocorre somente devido à perda das populações locais. Assim, a compreensão dos fatores relacionados à persistência das espécies emerge a partir de estudos da dinâmica de suas populações (Krebs 2002, Levins 2009).

Em especial o bioma Mata Atlântica requer estudos sobre a conservação das populações das espécies que nele ocorrem. A Mata Atlântica é considerada um dos mais importantes hotspots de biodiversidade (Myers et al 2000), ou seja, uma área com altíssima diversidade e endemismo, mas sujeita a intensa e imediata pressão sobre seus remanescentes florestais. Contudo, o conhecimento sobre indicadores ecológicos avança lentamente em relação à velocidade da degradação (Pinto et al 2006). Pequenos marsupiais e roedores (com menos de $1 \mathrm{~kg}$ ) formam o grupo ecológico mais diversificado de mamíferos do Brasil e da Mata Atlântica (Costa et al 2005, Paglia et al 2012). Estes animais desempenham papéis ecológicos importantes nestas florestas, sendo dispersores de sementes e fungos micorrízicos (e.g. Mangan \& Adler 2000, Colgan \& Claridge 2002, Vieira et al 2003, Pimentel \& Tabarelli 2004) e predadores de sementes e plântulas (Sánchez-Cordero \& Martinez-Gallardo 1998, Vieira et al 2003). Parte das espécies é fortemente 
associada à habitats florestais, não ocupando ambientes abertos ou alterados do entorno (Feliciano et al 2002, Pardini 2004, Lira et al 2007, Umetsu \& Pardini 2007), sendo fortemente afetados pelo desmatamento e alteração das florestas (Pardini et al. 2010).

Além de diversificados e ameaçados pelas ações antrópicas, pequenos mamíferos possibilitam o estudo de dinâmica populacional em curto período de tempo, uma vez que apresentam ciclos de vida curtos, com rápido "turnover" da população (Fonseca \& Kierulff 1989, Feliciano et al 2002, Barros 2006), o que permite a obtenção de informações sobre múltiplas gerações em estudos de duração relativamente curta. As espécies deste grupo também apresentam áreas de vida pequenas (Lira et al 2007, Püttker 2006), o que torna mais eficaz a obtenção dos dados através dos métodos de captura e recaptura, ao permitir a captura de uma boa parcela da população numa área de estudo restrita. No entanto, como para outros grupos de animais e plantas, boa parte das espécies de pequenos mamíferos são bastante raras localmente, e a grande maioria foi pouco estudada (Costa et al 2005). Assim, estudos de dinâmica populacional, essenciais para uma avaliação efetiva das categorias de ameaça e do planejamento de estratégias de conservação para este grupo (Costa et al 2005) exigem métodos de campo eficientes e grandes esforços de captura.

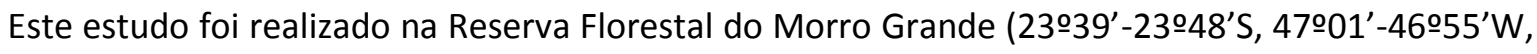
Cotia, São Paulo), uma área de 9400 ha de floresta conectada com as matas da Serra do Mar, fazendo parte do maior continuo de Mata Atlântica remanescente no Brasil. A fauna de pequenos mamíferos não-voadores da reserva é bastante diversa e inclui muitas espécies raras e endêmicas da Mata Atlântica (Pardini \& Umetsu 2006). Através do acompanhamento durante 21 meses por captura-marcação-recaptura das populações de pequenos mamíferos em três grades de 2 ha, esta tese tem dois grandes objetivos distintos: (1) Contribuir com a compreensão de como fatores ambientais afetam as flutuações de parâmetros populacionais, principalmente sobrevivência, recrutamento e reprodução, de roedores (capítulo 1) e marsupiais (capítulo 2). Mais especificamente, como fatores climáticos afetam a demanda conflitante (trade-off) entre 
reprodução e sobrevivência (Fig. 1), e quais são os gatilhos ambientais para a reprodução sazonal em marsupiais (Fig. 2); (2) Contribuir com a compreensão de como o tipo de armadilha, as características das indivíduos e as condições ambientais interagem para determinar o sucesso de captura (Fig. 3), visando identificar diretrizes para protocolos mais eficientes de amostragem de pequenos mamíferos. Os capítulos já estão preparados para submissão e por isso foram escritos em inglês.

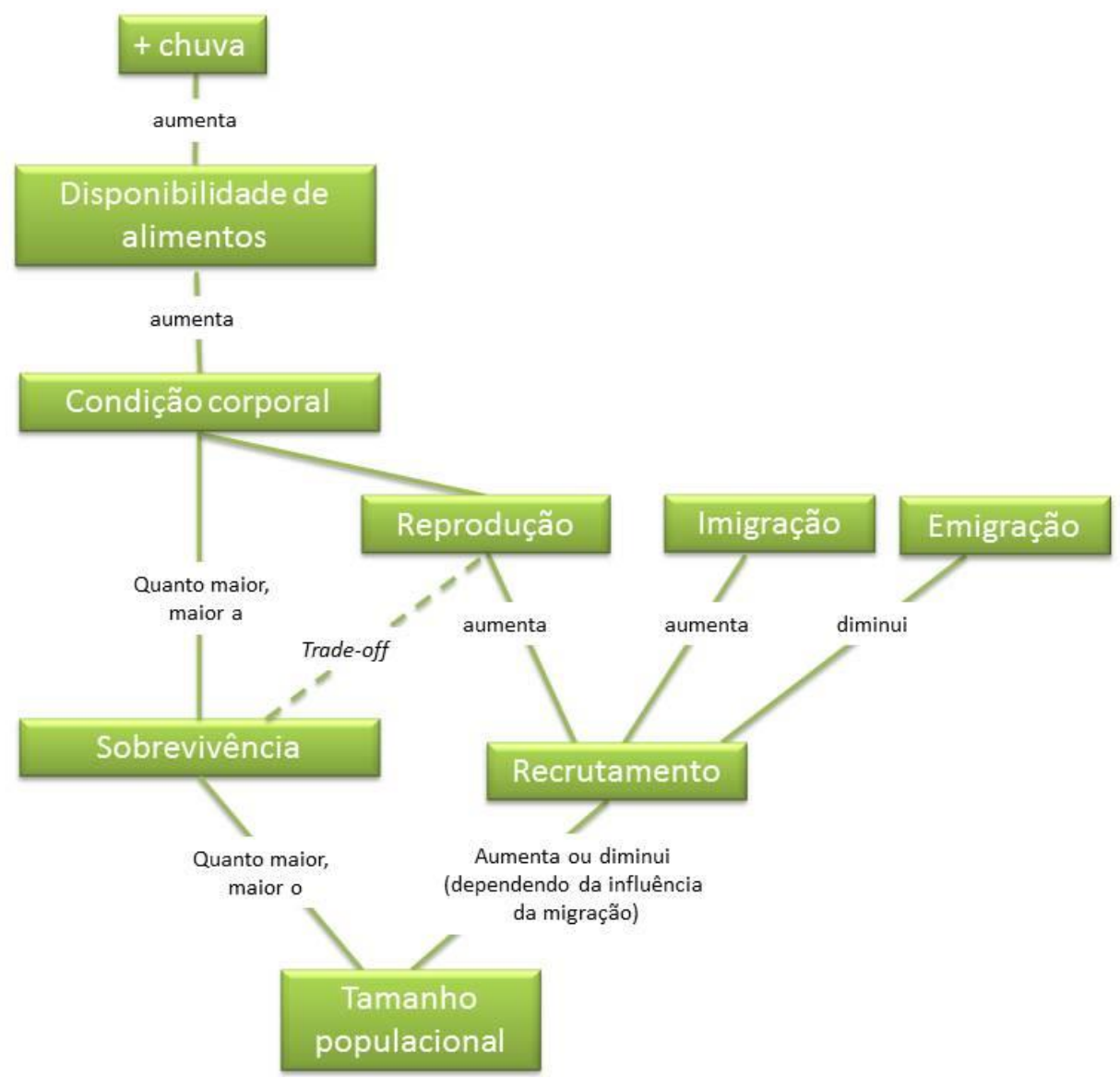

Figura 1: Mapa conceitual da relação da disponibilidade de alimentos via precipitação com os parâmetros da dinâmica populacional. O tamanho de uma população em um determinado período no tempo é dado pelo somatório dos indivíduos que sobreviveram do tempo anterior até o próximo, mais os indivíduos que foram recrutados nesse intervalo de tempo. O recrutamento é dado pelo somatório dos indivíduos que imigraram para a população mais os indivíduos que nasceram neste intervalo de tempo. Tanto a sobrevivência quanto o recrutamento via reprodução podem variar em função da disponibilidade de alimento no ambiente, uma vez que quanto melhor alimentado melhor a condição corpórea do indivíduo, maior as chances de sobrevivência e maior a energia para investimento em reprodução. Indiretamente essa melhor condição do indivíduo pode ser relacionada à quantidade de chuva no ambiente, uma vez que a disponibilidade tanto de artrópodes como de frutos (principais itens da dieta para a maioria das espécies de pequenos mamíferos) são maiores no período de maior precipitação. Como tanto sobrevivência como reprodução dependem da disponibilidade de recursos alimentares, e os custos energéticos da reprodução são altos, pode haver uma demanda conflitante (trade-off) entre sobrevivência e reprodução, que em marsupiais pode ser extrema, resultando em semelparidade (i.e. mortalidade elevada após a reprodução). 


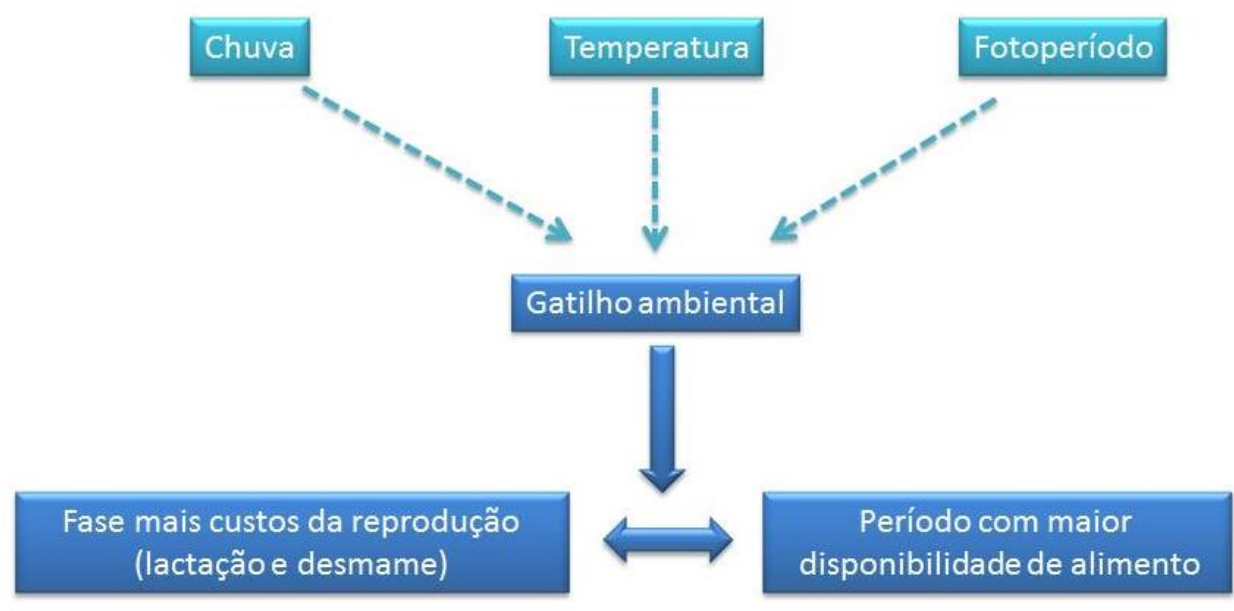

Figura 2: Mapa conceitual dos possíveis gatilhos ambientais que permitiriam que a fase mais custosa (lactação e desmame) da reprodução sazonal de espécies de marsupiais seja coincidente com o período de maior disponibilidade de recursos alimentares.

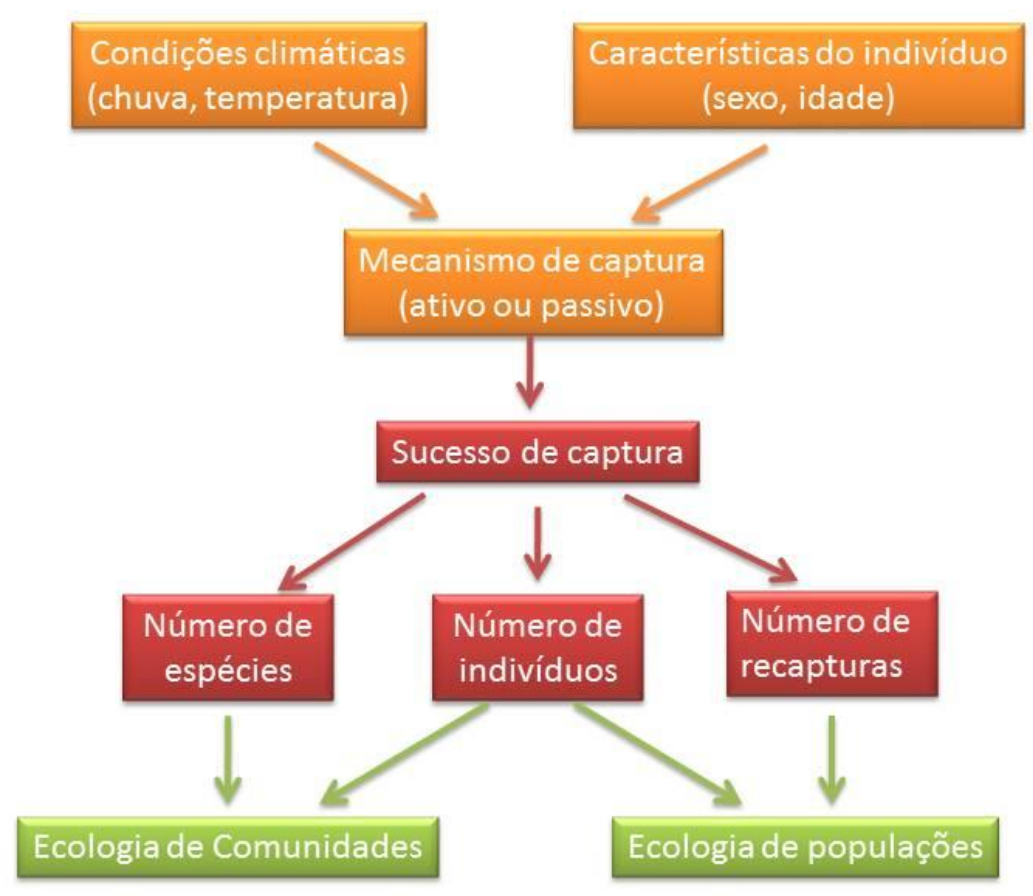

Figura 3: Mapa conceitual dos principais fatores (características dos indivíduos e condições climáticas) que podem interagir com o mecanismo de captura das armadilhas, afetando diferentes aspectos do sucesso de captura (número de espécies, indivíduos ou recapturas). Estas interações vão definir quais protocolos de captura são mais eficientes para estudos de comunidade e populações, já que estes requerem dados diferentes. 


\section{Capítulo 1}

Effects of rainfall on population dynamics of Atlantic Forest rodents: Evidence of a trade-off between survival and reproduction
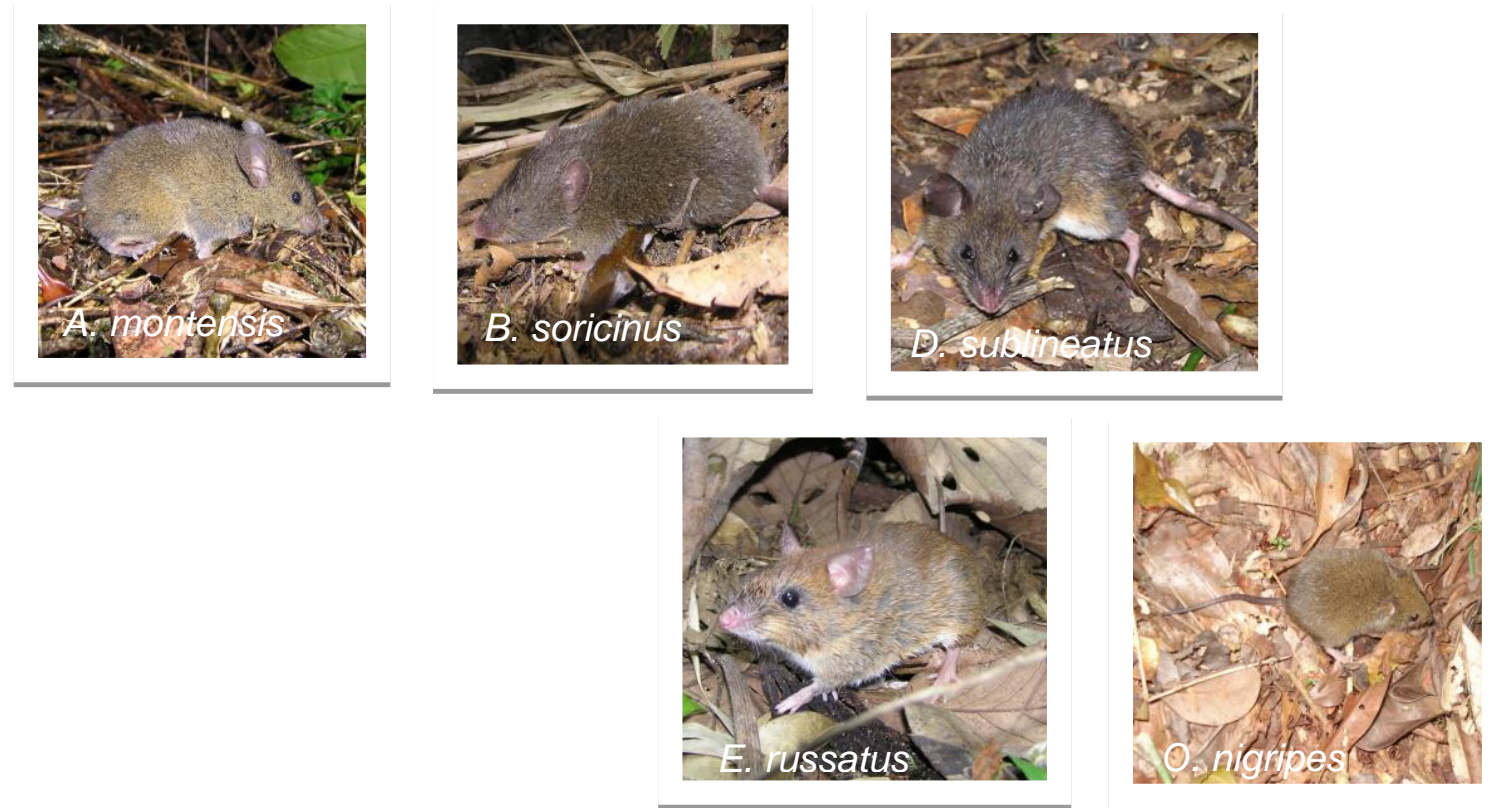


\title{
CAPÍtULO 1
}

\section{EFFECTS OF RAINFALL ON POPULATION DYNAMICS OF ATLANTIC FOREST RODENTS:}

\section{EVIDENCE OF A TRADE-OFF BETWEEN SURVIVAL AND REPRODUCTION}

\author{
CAMILA dos SANTOS de BARROS ${ }^{1}$, TIM COULSON $^{2}$, CRISTINA BANKS-LEITE ${ }^{2}$, THOMAS PÜTTKER $^{3}$ \& RENATA \\ PARDINI $^{3}$ \\ ${ }^{1}$ Departamento de Ecologia and ${ }^{3}$ Departamento de Zoologia, Instituto de Biocências, \\ Universidade de São Paulo, Rua do Matão, 321, trav. 14, 05508-900, São Paulo, SP, Brasil. \\ ${ }^{2}$ Department of Biology, Imperial College London, Silwood Park, Ascot, Berkshire, SL5 7PY, UK.
}

\section{Abstract}

Physiological costs of reproduction are the most significant component underlying vertebrate lifehistory trade-offs. Understanding reproduction is central to understand population fluctuation because, besides its effects on population size (i.e. addition of individuals), its energetic requirements can affect body condition, survival probability, and/or future reproduction of the parent generation. Reproduction is frequently associated with food availability, which in turn is highly correlated to rainfall in tropical environments. Using a capture-recapture dataset, comprising three two-ha grids sampled for almost two years, we investigated the importance of rainfall on reproduction and population dynamics of four small rodents in the Atlantic Forest. More specifically, we investigated the effects of rainfall on survival and recruitment rates, on the frequency of reproductive females and on individual body condition aiming at testing for the existence of live-history trade-offs. If there is a trade-off between reproduction and survival it would be expected that rainfall, as a proxy to food availability, positively affect recruitment (via reproduction) and negatively affect survival, because extra energy obtained during periods with 
high food availability would be allocated to reproduction instead of body condition. Our results showed that rainfall negatively affected survival rates, had a positive relationship with the frequency of reproductive females and that body condition was constant over time, thereby bringing evidence of the occurrence of a trade-off between survival and reproduction.

Keywords: Akodon, Delomys, demography, Euryoryzomys, physiological trade-offs, life-history traits, Oligoryzomys.

\section{Introduction}

Physiological costs of reproduction are the most significant component underlying vertebrate lifehistory trade-offs (Stearns 1992). As such, they are directly linked to the two main demographic parameters responsible for fluctuations in population growth and abundance: survival and recruitment rates (Krebs 2002). Not only new-born individuals contributes to recruitment rates, but also the energetic investment in current reproduction can lead to declined body condition, and lower survival and/or future reproduction (Speakman 2008).

Fluctuations in abundance are a consequence of the balance of gains and losses of individuals, through variation in survival and recruitment rates (Krebs 2002). It is quite clear that food resource availability is one of the main determinants of these population parameters in small mammals (Reis et al 2006, Prevedello et al 2013). Food resource availability is usually determined by rainfall (Bergallo \& Magnusson 1999), which makes rainfall one of the main exogenous factors affecting population dynamics. The rainfall effect can be delayed as a lag of time between increased rainfall and plants to set seeds, insects to proliferate, or mice to reproduce and their progeny enter the trappable population may occur (Bergallo \& Magnusson 1999, Luis et al 2010, Thibauld et al 2010). 
A trade-off between survival and reproduction can arise when the costs of reproduction are high, i.e. when diverting resources into reproduction leads to morphological and physiological changes in hormonal regulation that affect immunocompetence, as well as changes in physical activity and thermoregulation, which all can increase mortality after reproduction (Stearns 1992, Harshman \& Zera 2006, Speakman 2008). These reproduction trade-offs can either decrease the success of future reproduction in relation to current reproduction, or the survival rates of the population (Stearns 1992, Speakman 2008). Future reproduction as a negative function of current reproduction has been recorded for long-lived vertebrates as, for example, red deer (Cluttonbrock et al 1983, Moyes et al 2006), leatherback sea turtle (Rivalan et al 2005) and lizards (Bleu et al 2013). On the other hand, although investment in reproduction has been shown to be associated with a decrease in survival in large mammals (Clutton-Brock et al 1983), this association seems to be more common in short-lived species. In brown anoles, experimentally reducing reproductive investment via ovariectomy dramatically increased survival over both the immediate breeding season and the subsequent post-breeding period (Cox et al 2010). In small mammals, both reduced survival and fecundity of the mothers were detected as consequence of the costs of reproduction (Koivula et al 2003).

In small rodents, in particular, costs of reproduction are high and energy intake during gestation increases by $18-25 \%$, and during lactation by $66-188 \%$ (Gittleman \& Thompson 1988). It is thus understandable why food resource availability, and thereby rainfall as a correlate of food availability (Bergallo \& Magnusson 1999, Leiner \& Silva 2007), is one of the main determinants of population fluctuations and demographic parameters of small mammals (Bergallo \& Magnusson 19999, Prevedello et al 2013). In Neotropical small rodents, for instance, while reproduction is generally continuous throughout the year (Cerqueira et al. 1993, Gentile et al. 2000, Graipel et al 2006, D'Andrea et al. 2007), there is generally a peak in number of offspring during the periods with highest food availability, which is the warm-wet season for fruit and arthropod consumers and the cold-dry season for granivores (Bergallo \& Magnusson 1999, Feliciano et al 2002, 
D'Andrea et al 2007). It is less clear, however, to which extent survival rates are influenced by rainfall or food availability, with evidence showing positive, negative and even no influence of rainfall (Bergallo \& Magnusson 1999, Díaz \& Alonso 2003). When the energy gained in periods of higher food availability is allocated to increase body condition, it would be expected that survival rates increase in these periods. However, if there is a trade-off between reproduction and survival in these species, and the energy of periods with higher food availability is allocated to reproduction instead of body condition, rainfall as a proxy to food availability should positively affect recruitment (via reproduction) and negatively affect survival.

Among vertebrates, small mammals are probably the most appropriate group for population dynamics studies, since they have short life cycles and fast population turnover (Feliciano et al. 2002, Antunes et al 2010), allowing the study of multiple generations in a relatively short period. These animals have also relatively small home ranges (Gentile et al 2000, Püttker 2006), which means that capture-recapture methods are highly efficient, as a large proportion of the population can be monitored in a small area. Nevertheless, not much is known about the influence of rainfall on survival and recruitment and on reproduction trade-offs in Neotropical small mammals, since most species are rare, making it difficult to obtain enough captures and recaptures for estimation of demographic parameters and their spatial or temporal fluctuations (Costa et al. 2005). Using a capture-recapture dataset, comprising three two-ha grids sampled for almost two years, we were able to investigate the effects of rainfall on population dynamics of four small rodents in the Atlantic Forest. More specifically, considering that rainfall is an indirect measure of resource availability, we investigated the effects of rainfall on survival and recruitment rates, as well as on the frequency of reproductive females and on individual body condition aiming at testing for the existence of live-history trade-offs. 


\section{Material and Methods}

Rodent species

The species investigated are the most common small mammal species in the study area, allowing a sufficient number of captures required for the estimation of population parameters (Williams et al 2002). The rodent Akodon montensis has an insectivore-omnivorous diet (Talamoni et al 2008, Paglia et al 2012). Delomys sublineatus and Euryoryzomys russatus presented a similar diet, mostly composed of fruits but also consuming arthopods (Pinotti et al 2011, Paglia et al 2012). Oligoryzomys nigripes is the least insectivorous among these species presenting a higher proportion of vegetal material in its stomach (Talamoni et al 2008, Pinotti et al 2011).

\section{Study Site}

The study was conducted at the Morro Grande Forest Reserve $\left(23^{\circ} 39^{\prime}-23^{\circ} 48^{\prime} \mathrm{S}, 47^{\circ} 01^{\prime}-46^{\circ} 55^{\prime} \mathrm{W}\right.$, Cotia, São Paulo, Fig. 1.1), which comprises 9400 ha of forest and is connected with the largest continuous area of Atlantic Forest in Brazil (the Serra do Mar). The Reserve is covered by montane rainforest at different stages of regeneration (Metzger et al 2006). Altitude varies from 860 to $1075 \mathrm{~m}$ above sea level. The mean maximum temperature $27^{\circ} \mathrm{C}$, and the mean minimum $11^{\circ} \mathrm{C}$. Average rainfall is $1339 \mathrm{~mm}$ per year and the warm and wet season from September to March.

Data collection

We placed three 2 ha trap grids (100 m x $200 \mathrm{~m}$ ) at least $2 \mathrm{~km}$ apart from each other (Fig. 1.1), in forests in mid stage of regeneration. Each grid comprised eleven 100-m long lines, $20 \mathrm{~m}$ apart from each other, all consisting of 11 trap stations every $10 \mathrm{~m}$. Six alternated lines had 11 Sherman traps $(37.5 \times 10.0 \times 12.0 \mathrm{~cm}$ or $23.0 \times 7.5 \times 8.5 \mathrm{~cm})$ on the ground. The other five lines had 11 pitfall traps ( $60 \mathrm{~L}$ buckets buried at the ground, connected by $50 \mathrm{~cm}$ high drift-fences) besides the Sherman traps, totaling 121 Sherman traps and 55 pitfall traps per grid. In order to reduce mortality in pitfall traps we (1) made holes at the bottom of the buckets in order to prevent 
accumulation of rainwater, (2) placed Styrofoam at the bottom of the buckets for flotation in the event of flooding, (3) placed food in the bucket for feeding animals at night, and (4) used bucket lids as a rain cover at $50 \mathrm{~cm}$ from the ground. Traps received daily baits of a mashed banana, cornmeal, peanut butter and sardines.

We performed 21 primary five-night trapping sessions between March 2008 and October 2009. Interval between sessions varied from 16 to 30 days (mean of 23.4 days). Captured individuals were marked with aluminum tags with unique codes, allowing individual recognition. For each capture we registered the species, sex, weight and reproductive condition of females. We considered females in reproductive activity when they present swollen teats or were pregnant. Voucher specimens of all species were collected in a pilot sample, identified by experts, and are kept in the Department of Zoology, University of São Paulo. Monthly rainfall data were obtained from the agency that manages the Reserve.

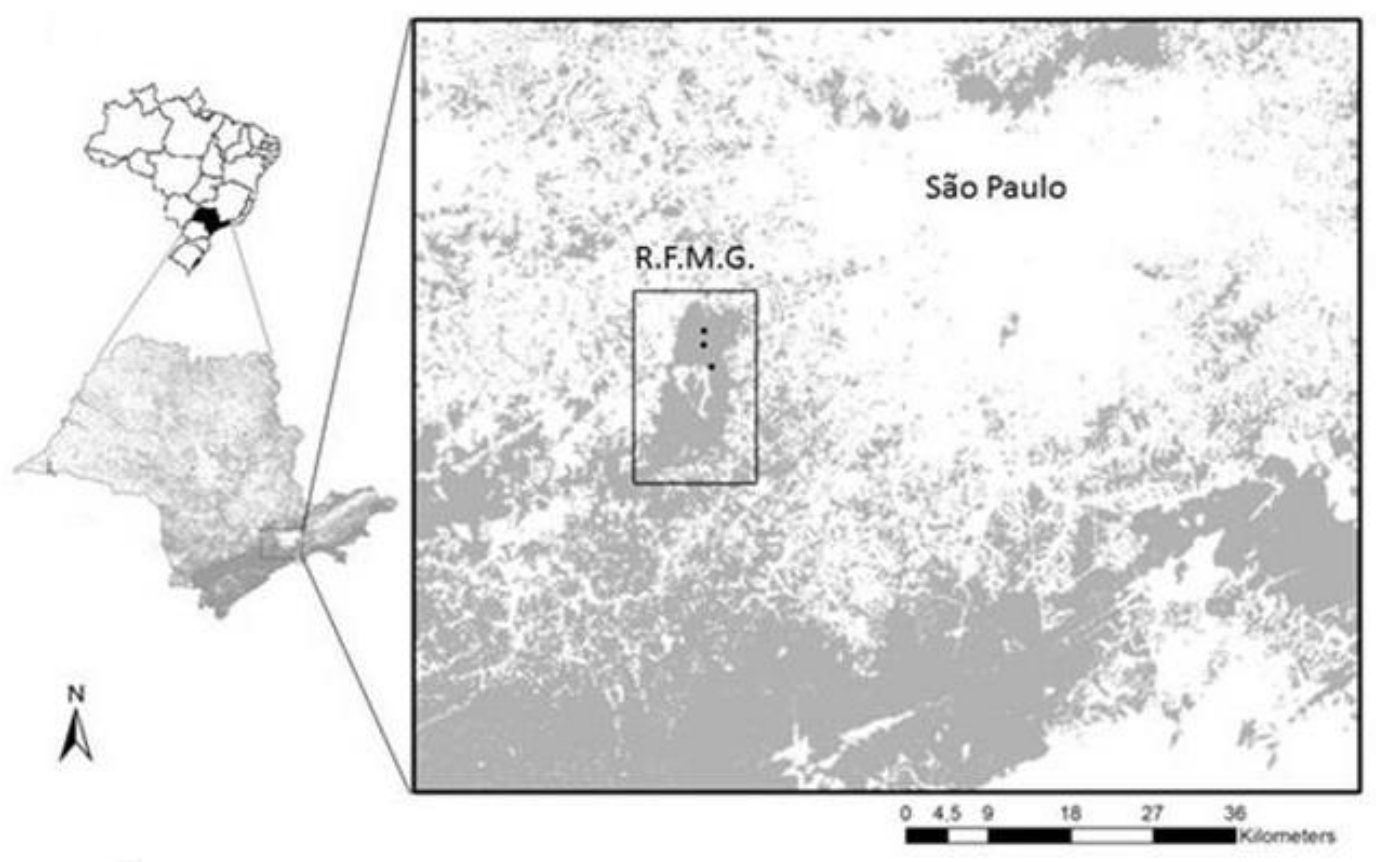

Figure 1.1: Morro Grande Forest Reserve (R.F.M.G.) in São Paulo State, Brazil near to São Paulo City. Black dots represent the 2-ha trapping grids (M1, M2 and M3). Gray areas represent forest remnants. 


\section{Data analysis}

In all the analysis we accessed the plausibility of candidate models using Akaike's Information Criterion corrected for small samples (AICc, Williams et al. 2002, Burnham \& Anderson 2002). AICc values of each model were subtracted from the AICc value of the first-ranked model $(\Delta \mathrm{i})$, and models were considered equally plausible with $\Delta \mathrm{i} \leq 2$ (Burnham \& Anderson 2002). In case that more than one model was selected, to distinguish among these equally plausible models we considered the most parsimonious model (the one with the lowest number of parameters Lebreton et al 1992) if the Akaike weight was considerably more than half of the Akaike weight of the first-ranked model, or otherwise we choose the first-ranked model.

Survival and recruitment with capture-mark-recapture models: We implemented Pradel models (Pradel 1996) and Pollock's robust design models (Pollock 1982, Kendal et al 1997) in program MARK version 6.1 (White \& Burnhan 1999). Because the dataset did not allow heavily parameterized models, the estimation of population size $(\mathrm{N})$ was conditioned out of the likelihood using Huggins' closed-capture models within primary capture sessions (Huggins 1991). Based on experience during field work and evaluation of previous models, capture probability (p) and recapture probability (c) were considered equivalent and dependent on sampling session. To evaluate if rainfall influences survival and recruitment rates, for each of the four most abundant species (Table S1.1) we compared a set of candidate models that considered survival and recruitment rates with spatial variation only, varying among the three sites (capture grids), with spatial and temporal variation (varying among the sites and among capture sessions), or with spatial variation and as a function of rainfall (Table 1.1). Because the effect of rainfall on food availability might not be immediate, we included different candidate models considering rainfall without time lag, with a time lag of one month, and with a time lag of two months in both survival and recruitment rates (Table 1.1). 
Reproduction activity: To investigate if reproduction activity is affected by rainfall (since recruitment rates also includes migration), we compared a set of candidate generalized linear models (GLM). Reproduction activity was computed as the frequency of reproductive females in each capture session, which was modeled as a binomial variable. We assumed that reproductive and non-reproductive females had the same capture probability. The independent variables included in the models were the same as in the models described above for estimating survival and recruitment rates, and followed the same notation (Table 1.1).

Body condition: A body condition index was calculated by adult per capture session as body mass/body length ${ }^{3}$ (Peig \& Green 2010). Classification as adult was based on the minimum weight of a reproductive individual, all animals above this weight were classified as adults (minimum adult weight of $A$. montensis: $\hat{\sigma}=19.0 \mathrm{~g}, ~ ๆ=25.0 \mathrm{~g} ; B$. soricinus $\widehat{\partial}=25.0 \mathrm{~g}, q=23.0 \mathrm{~g} ; D$. sublineatus $\widehat{\partial}=30.0 \mathrm{~g}, q=38.0 \mathrm{~g} ;$ E. russatus $\hat{\partial}=38.0 \mathrm{~g}, q=52.0 \mathrm{~g}, O$. nigripes $\hat{\partial}=12.0 \mathrm{~g}, q=13.0 \mathrm{~g}) . \mathrm{We}$ compared a set of candidate linear mixed effect models containing the same independent variables used for estimating survival and recruitment rates (in this case considered as fixed factors, Table 1.1), but taking into account the dependency among data from the same individual by considering the individual as a random factor (Bolker et al 2008). Models for both the frequency of reproductive females and body condition were run in program R, version 2.14.0 ( $R$ Development Core Team 2011).

Table 1.1: Description of notations used to indicate the independent variables included in models for survival rates, recruitment rates, frequency of reproductive females and body condition. Model notation follows that of linear models, as $a+b$ contains additive effects only.

\begin{tabular}{ll}
\hline Notation & Modeled parameters as a function of \\
\hline cte & Spatial variation (among grids) only \\
$\mathrm{t}$ & Spatial and temporal (among capture sessions) variation \\
ppt & Spatial variation and same month rainfall \\
ppt 1 & Spatial variation and rainfall of previous month \\
ppt2 & Spatial variation and rainfall of two months before \\
ppt + ppt1 & Spatial variation and rainfall of the same and previous month \\
ppt1 + ppt2 & Spatial variation and rainfall of the month before and two months before \\
ppt + ppt1 +ppt2 & Spatial variation and rainfall of the same month, previous month and two \\
& months before \\
\hline
\end{tabular}




\section{Results}

In a total of 55440 trap-nights, we achieved 4065 captures of 1380 individuals of 24 small mammal species, 15 rodents and nine marsupials (Table S1.1). The rodent species with more captures providing sufficient data for analysis were A. montensis, D. sublineatus, E. russatus and O. nigripes (over 470 captures up to 1358 captures; Table S1.1).

We tested for population closure within primary capture sessions using the Stanley and Burnham test for closure (Stanley and Burnham 1999) in program CloseTest. We assumed population closure within primary capture sessions because only in a small number of primary capture sessions the assumption of closure was violated and the primary capture sessions consisted of only five consecutive days.

The most plausible models indicate that survival rates are a function of rainfall of the same month for $A$. montensis, of the previous month (one month time lag) for $D$. sublineatus, of two months before (two month time lag) for $O$. nigripes, and an additive effect of the same month, the previous month and two months before for E. russatus (Table 1.2). The relationship between survival rate and rainfall was negative for all species in all grids excepting one grid for $E$. russatus and $D$. sublineatus (Fig 1.2). Survival rates were thus mostly negatively related to rainfall, but with different time lags among species (Fig S1.1).

In contrast, the most plausible models indicate that recruitment rates, while varying temporally across sampling sessions, the variation is not explained by rainfall for all species excepting $E$. russatus (Table 1.2). For E. russatus recruitment rates were positively influenced by rainfall in all sites (one month time lag; Table 1.2, Fig 1.3).

The frequency of reproductive females was influenced by rainfall with no time lag for all species excepting 0 . nigripes (Table 1.3). Differently to the observed for survival rates, this relationship was positive for all three species in all sites but one for D. sublineatus (Fig 1.4). Frequency of 
reproductive females of $O$. nigripes is not a function of rainfall or any other factors co-varying with capture sessions, as the most plausible model describes its reproduction as constant during the study (Table 1.3, Fig 1.4).

Finally, the most plausible models indicate that rainfall does not influence body condition of adults in any species; neither by any other factors co-varying with capture sessions (Table 1.4). The constant model was the best model to describe body condition for all species in all sites (Table 1.4, Fig 1.5). 
Table 1.2: Population dynamics (survival-phi and recruitment-f) model selection of four rodent species of the Morro Grande Forest Reserve as a function of rainfall (ppt), capture sessions ( $t$ ) or neither of those (constant model, cte). $\Delta_{\mathrm{i}}$ : difference of AICC value to the best model, $\omega_{\mathrm{i}}$ Akaike weight, $\mathrm{K}$ : number of parameters. Capture probability is always equal to recapture probability and both were modeled as a function of capture sessions. Grids of capture were included as a co-variable of both parameters in all models (including the constant). Presented are models with $\omega_{\mathrm{i}}>0.01$, and highlighted in bold the most plausible model.

\begin{tabular}{|c|c|c|c|c|}
\hline & & $\mathrm{K}$ & $\Delta_{\mathrm{i}}$ & $\omega_{\mathrm{i}}$ \\
\hline \multicolumn{5}{|l|}{ A. montensis } \\
\hline phi(ppt + ppt1) & $f(t)$ & 50 & 0 & 0.45 \\
\hline phi(ppt) & $f(t)$ & 47 & 0.62 & 0.33 \\
\hline phi(t) & $f(t)$ & 65 & 2.15 & 0.15 \\
\hline phi(ppt + ppt1 + ppt2) & $f(t)$ & 53 & 3.98 & 0.06 \\
\hline \multicolumn{5}{|l|}{ D. sublineatus } \\
\hline phi(ppt1) & $f(t)$ & 47 & 0 & 0.67 \\
\hline phi(ppt2) & $f(t)$ & 47 & 3.29 & 0.13 \\
\hline phi(ppt + ppt1) & $f(t)$ & 50 & 3.82 & 0.10 \\
\hline phi(ppt) & $f(t)$ & 47 & 5.56 & 0.04 \\
\hline phi(ppt1) & $f(p p t)$ & 29 & 7.14 & 0.02 \\
\hline \multicolumn{5}{|l|}{ E. russatus } \\
\hline phi(ppt + ppt1 + ppt2) & $f(p p t 1)$ & 35 & 0 & 0.48 \\
\hline phi(ppt + ppt1 + ppt2) & f(cte) & 34 & 3.66 & 0.08 \\
\hline phi(ppt) & $f(p p 1)$ & 32 & 4.84 & 0.04 \\
\hline phi(ppt + ppt1 + ppt2) & $f(p p t)$ & 29 & 4.90 & 0.04 \\
\hline phi(ppt + ppt1 + ppt2) & $f(p p t 2)$ & 35 & 4.98 & 0.04 \\
\hline phi(ppt1 + ppt2) & $f(p p t 1)$ & 35 & 5.07 & 0.04 \\
\hline phi(ppt2) & $f(p p t 1)$ & 32 & 5.09 & 0.04 \\
\hline phi(ppt2) & $\mathrm{f}(\mathrm{cte})$ & 29 & 5.43 & 0.03 \\
\hline phi(ppt + ppt1 + ppt2) & $f(p p t 1+p p t 2)$ & 28 & 5.58 & 0.03 \\
\hline phi(ppt1 + ppt2) & f(cte) & 38 & 5.62 & 0.03 \\
\hline phi(ppt + ppt1 + ppt2) & $f(p p t+p p t 1)$ & 31 & 5.64 & 0.03 \\
\hline
\end{tabular}

O. nigripes

\begin{tabular}{llrrr} 
phi(ppt2) & $\mathbf{f}(\mathbf{t})$ & $\mathbf{4 7}$ & $\mathbf{0}$ & $\mathbf{0 . 4 1}$ \\
phi(ppt) & $\mathrm{f}(\mathrm{t})$ & 47 & 1.23 & 0.22 \\
phi(cte) & $\mathrm{f}(\mathrm{t})$ & 46 & 2.00 & 0.15 \\
phi(ppt1+ppt2) & $\mathrm{f}(\mathrm{t})$ & 50 & 3.18 & 0.08 \\
phi(ppt + ppt1) & $\mathrm{f}(\mathrm{t})$ & 50 & 3.49 & 0.07 \\
phi(ppt1) & $\mathrm{f}(\mathrm{t})$ & 47 & 5.24 & 0.03 \\
phi(ppt + ppt1 + ppt2) & $\mathrm{f}(\mathrm{t})$ & 53 & 5.43 & 0.03 \\
\hline
\end{tabular}


Table 1.3: Model selection of frequency of reproductive females of four rodent species of Morro Grande Forest Reserve as a function of rainfall (ppt), capture sessions ( $\mathrm{t}$ ) or neither of those (constant model, cte). $\Delta_{\mathrm{i}}$ : difference of AICC value to the best model, $\omega_{\mathrm{i}}$ : Akaike weight, K: number of parameters. Grids of capture were included as a co-variable of both parameters in all models (including the constant). Highlighted in bold are the most plausible model.

\begin{tabular}{|c|c|c|c|c|}
\hline & & $\mathrm{K}$ & $\Delta_{\mathrm{i}}$ & $\omega_{i}$ \\
\hline \multicolumn{5}{|l|}{ A. montensis } \\
\hline & ppt & 4 & 0 & 0.61 \\
\hline & ppt+ppt1 & 5 & 1.7 & 0.26 \\
\hline & $p p t+p p t 1+p p t 2$ & 6 & 4.1 & 0.08 \\
\hline & $\mathrm{t}$ & 23 & 5.2 & 0.05 \\
\hline & cte & 3 & 10.9 & 0.01 \\
\hline & ppt1 & 4 & 12.5 & 0.01 \\
\hline & ppt2 & 4 & 12.7 & 0.01 \\
\hline & ppt1+ppt2 & 5 & 14.6 & $<0.001$ \\
\hline \multicolumn{5}{|l|}{ D. sublineatus } \\
\hline & ppt & 4 & 0 & 0.33 \\
\hline & ppt1 & 4 & 1.3 & 0.17 \\
\hline & cte & 3 & 1.4 & 0.17 \\
\hline & ppt+ppt1 & 5 & 1.5 & 0.16 \\
\hline & ppt2 & 4 & 3.1 & 0.07 \\
\hline & ppt1+ppt2 & 5 & 3.6 & 0.05 \\
\hline & $p p t+p p t 1+p p t 2$ & 6 & 3.8 & 0.05 \\
\hline & $\mathrm{t}$ & 23 & 38.1 & $<0.001$ \\
\hline \multicolumn{5}{|l|}{ E. russatus } \\
\hline & ppt & 4 & 0 & 0.44 \\
\hline & $p p t+p p t 1+p p t 2$ & 6 & 1.9 & 0.18 \\
\hline & ppt+ppt1 & 5 & 2.4 & 0.13 \\
\hline & ppt2 & 4 & 2.4 & 0.13 \\
\hline & ppt1 & 4 & 3.8 & 0.07 \\
\hline & ppt1+ppt2 & 5 & 4.2 & 0.05 \\
\hline & cte & 3 & 14.2 & $<0.001$ \\
\hline & $\mathrm{t}$ & 23 & 51.0 & $<0.001$ \\
\hline \multicolumn{5}{|l|}{ O. nigripes } \\
\hline & cte & 3 & 0 & 0.84 \\
\hline & ppt1 & 4 & 5.7 & 0.05 \\
\hline & ppt & 4 & 6.0 & 0.04 \\
\hline & ppt2 & 4 & 6.1 & 0.04 \\
\hline & ppt1+ppt2 & 5 & 8.1 & 0.01 \\
\hline & ppt+ppt1 & 5 & 8.1 & 0.01 \\
\hline & $p p t+p p t 1+p p t 2$ & 6 & 10.5 & 0.01 \\
\hline & $\mathrm{t}$ & 23 & 36.8 & $<0.001$ \\
\hline
\end{tabular}


Table 1.4: Model selection for body condition index of four rodent species of Morro Grande Forest Reserve as a function of rainfall (ppt), capture sessions (t) or neither of those (constant model, cte). $\Delta_{\mathrm{i}}$ : difference of AICc value to the best model, $\omega_{\mathrm{i}}$ Akaike weight, $\mathrm{K}$ : number of parameters. Grids of capture were included as a co-variable of both parameters in all models (including the constant). Highlighted in bold are the most plausible model.

\begin{tabular}{lccc}
\hline & $\mathrm{K}$ & $\Delta_{\mathrm{i}}$ & $\omega_{\mathrm{i}}$ \\
\hline A. montensis & $\mathbf{5}$ & $\mathbf{0}$ & $\mathbf{1}$ \\
cte & 6 & 21.0 & $<0.001$ \\
ppt & 6 & 21.8 & $<0.001$ \\
ppt2 & 6 & 23.2 & $<0.001$ \\
ppt1 & 7 & 45.3 & $<0.001$ \\
ppt+ppt1 & 7 & 46.2 & $<0.001$ \\
ppt1+ppt2 & 8 & 69.1 & $<0.001$ \\
ppt+ppt1+ppt2 & 25 & 238.7 & $<0.001$ \\
$\mathrm{t}$ & & &
\end{tabular}

D. sublienatus

$\begin{array}{lccc}\text { cte } & \mathbf{5} & \mathbf{0} & \mathbf{1} \\ \text { ppt1 } & 6 & 23.1 & <0.001 \\ \text { ppt } & 6 & 24.0 & <0.001 \\ \text { ppt2 } & 6 & 24.4 & <0.001 \\ \text { ppt+ppt1 } & 7 & 46.5 & <0.001 \\ \text { ppt1+ppt2 } & 7 & 47.5 & <0.001 \\ \text { ppt+ppt1+ppt2 } & 8 & 70.8 & <0.001 \\ \text { t } & 25 & 228.1 & <0.001\end{array}$

E. russatus

$\begin{array}{lccc}\text { cte } & \mathbf{5} & \mathbf{0} & \mathbf{1} \\ \text { ppt1 } & 6 & 11.2 & <0.001 \\ \text { ppt2 } & 6 & 19.8 & <0.001 \\ \text { ppt } & 6 & 22.6 & <0.001 \\ \text { ppt1+ppt2 } & 7 & 33.0 & <0.001 \\ \text { ppt+ppt1 } & 7 & 35.7 & <0.001 \\ \text { ppt+ppt1+ppt2 } & 8 & 58.0 & <0.001 \\ \text { t } & 25 & 222.5 & <0.001\end{array}$

O. nigripes

$\begin{array}{lccc}\text { cte } & \mathbf{5} & \mathbf{0} & \mathbf{1} \\ \text { ppt2 } & 6 & 22.7 & <0.001 \\ \text { ppt1 } & 6 & 23.9 & <0.001 \\ \text { ppt } & 6 & 24.0 & <0.001 \\ \text { ppt1+ppt2 } & 7 & 46.7 & <0.001 \\ \text { ppt+ppt1 } & 7 & 47.8 & <0.001 \\ \text { ppt+ppt1+ppt2 } & 8 & 70.5 & <0.001 \\ \text { t } & 25 & 222.3 & <0.001\end{array}$



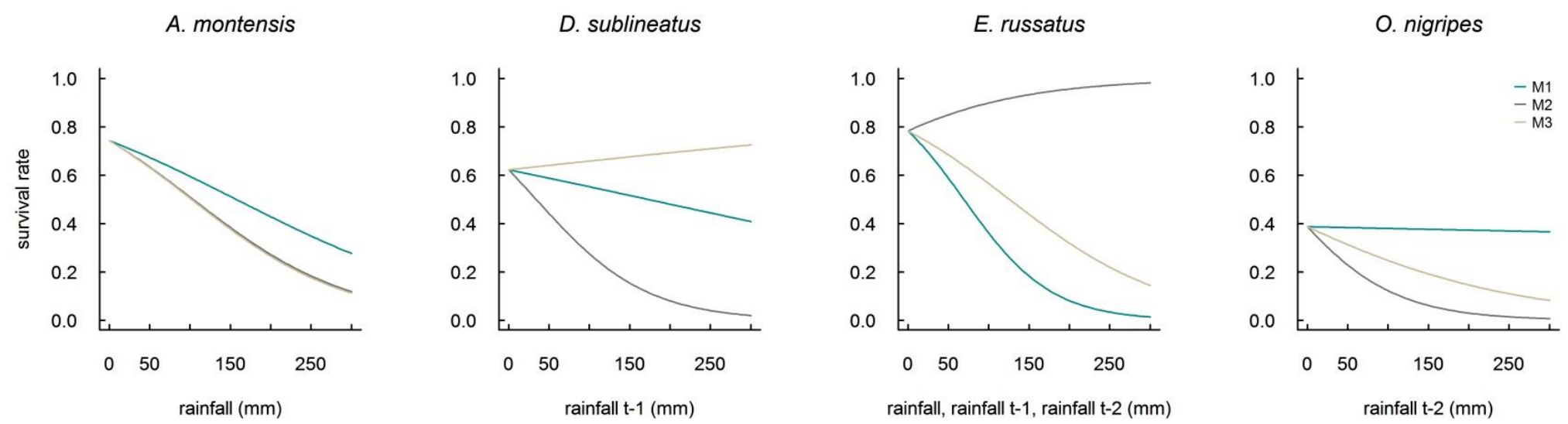

Figure 1.2: Survival rates as a function of rainfall for four rodent species in each grid (M1, M2, M3) of the Morro Grande Forest Reserve. Rainfall is presented with time lag when this was the most parsimonious model ( $\mathrm{t}-1$ : one month time lag; $\mathrm{t}-2$ : two month time lag).

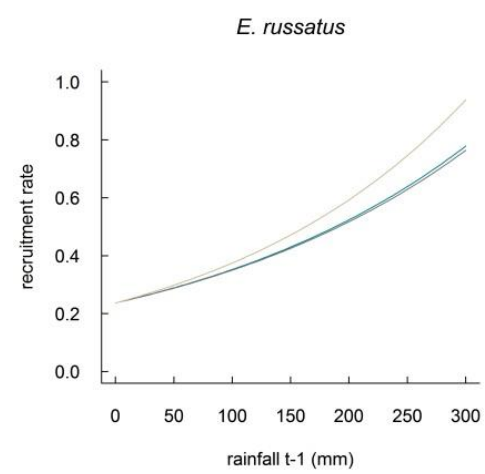

Figure 1.3: Recruitment rates as a function of rainfall of the previous month (t-1) for E. russatus in each grid (M1, M2, M3) of the Morro Grande Forest Reserve. 

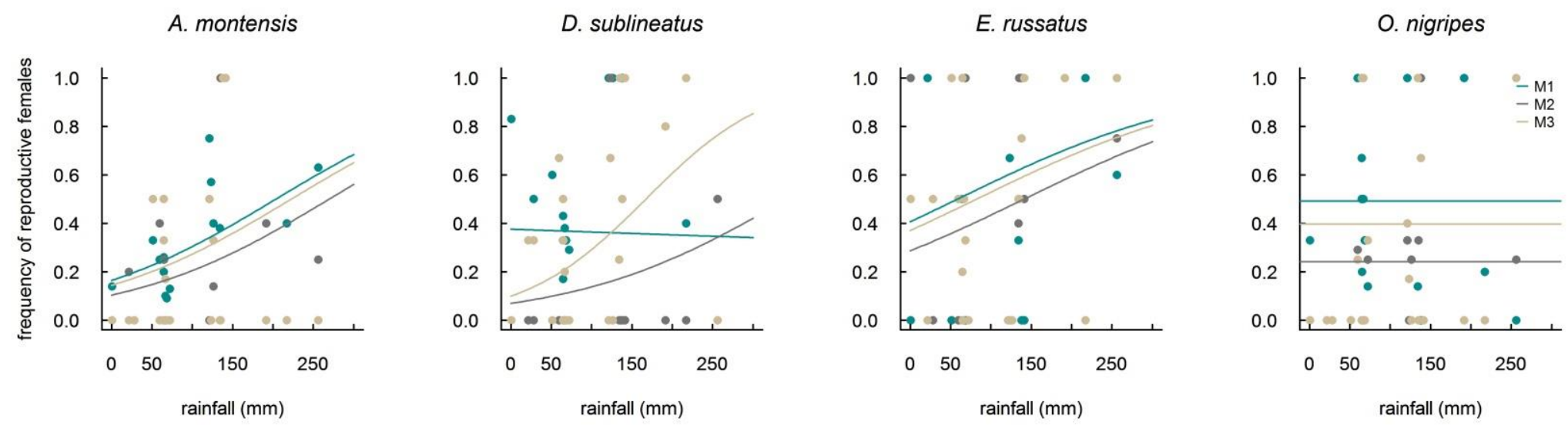

Figure 1.4: Frequency of reproductive females as a function of rainfall for four rodent species in each grid (M1, M2, M3) of the Morro Grande Forest Reserve.
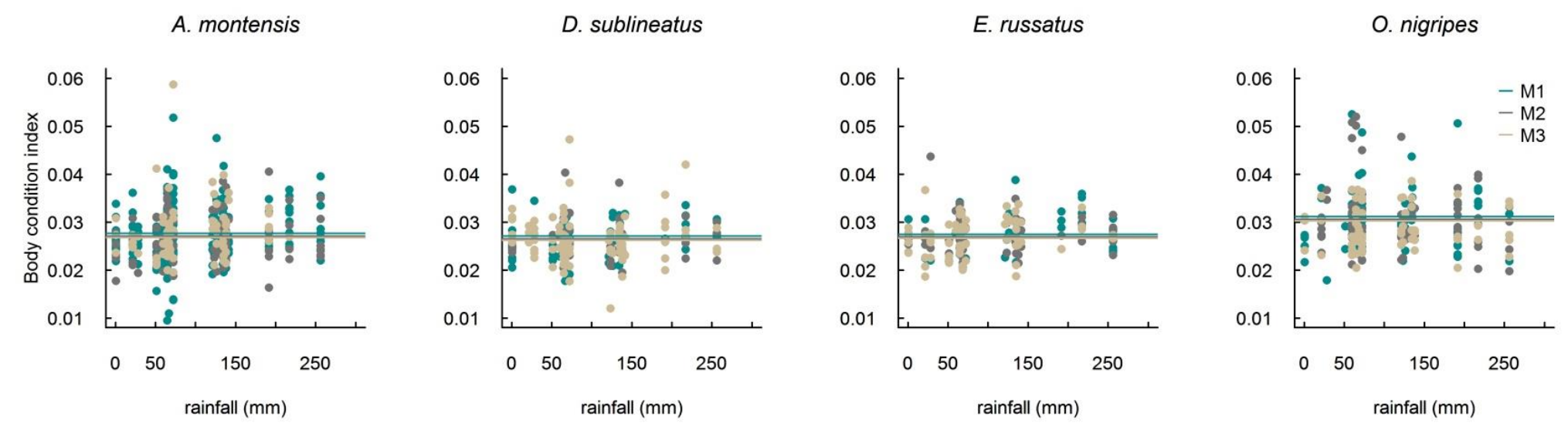

Figure 1.5: Temporal variation of body condition index for four rodent species in each grid (M1, M2, M3) of the Morro Grande Forest Reserve. Lines represent the estimates from the constant model. 


\section{Discussion}

Our results indicate that a trade-off between survival and reproduction could be the underlying factor of the decrease in the survival rates of rodent populations during wet periods in the Atlantic Forest. While the survival rate was negatively related to rainfall in all studied species, either recruitment rate or the frequency of reproductive females was positively related to rainfall in most species. Furthermore, body condition was not altered by rainfall, as expected if energy available in the wet period is allocated in reproduction instead of survival

Rainfall is usually associated with the availability of fruits and arthropod at the Atlantic Forest (Bergallo \& Magnusson 1999, Leiner et al 2008). Because reproduction is expected to occur during the period with higher resource availability, a positive relationship between recruitment rates and rainfall is expected if recruitment rates are mainly influenced by reproduction (rather than migration). However, variation in recruitment rates was explained by rainfall only in E. russatus. Considering that pregnancy of small rodents takes around one month (Merritt 2010) and recruitment rate in E. russatus was positively related to rainfall with one month time lag, the results are congruent with reproduction influencing recruitment as well as reproduction occurring during the time of highest rainfall, and recruitment of juveniles during the time of highest food availability. Since recruitment rates were not influenced by rainfall, they may be strongly influenced by immigration in the remaining three studied species - A. montensis, $D$. sublineatus, and $O$. nigripes. This seems a plausible hypothesis, since our grids were located in a continuous forest, facilitating the movement of individuals among populations/sub-populations. Prominence of immigration on recruitment rates has been shown for other small rodents in the Atlantic Forest (Akodon cursor and Necromys lasiurus, Feliciano et al 2002).

Indeed, reproductive activity (as measured by the frequency of reproductive females) was positively related to rainfall (with no time lag) in all species, excepting $O$. nigripes. Given that pregnancy is around one month in small rodents (Merritt 2010), the absence of a time lag in the 
relationship between rainfall and frequency of reproductive female suggest again that the litters are born mainly during the period of highest rainfall, and the phases of highest energy demand (lactation and weaning; Gittleman \& Thompson 1988) will occur during the period of highest food availability. Other studies describing the reproductive pattern of $A$. montensis and $E$. russatus also showed an increase in reproductive activity during the wet season (Graipel et al 2006, Couto \& Talamoni 2005, Antunes et al 2009, 2010, Bergallo \& Magnusson 1999, Bergallo et al 2004). This is the first study showing the reproductive patterns of $D$. sublineatus, but co-generic $D$. dorsalis also presented an increased reproductive activity during the wet season (Cadermatori et al 2005). The constant reproduction of $O$. nigripes might be a consequence of the generalist food habit of this species, being able to have use resources that increase in either the dry (small seeds) or the wet season (insects and fruits) (Vieira et al 2003, 2006, Pinotti et al 2011). In other regions, the reproduction activity of this species that is concentrated during the dry period (Feliciano et al 2002, Graipel et al 2006,Antunes et al 2009, Bonecker at al 2009).

On the other hand, survival rates in all four rodent species were negatively related to rainfall, and the relationships included one and/or two month time lag in most cases. A negative effect of rainfall without time lag, as observed for $A$. montensis and $E$. russatus, might be a consequence of an increased mortality caused by hypothermia or by predation of individuals forced to abandon flooding burrows (Speakman 2008). However, a delayed negative effect of rainfall, like we found in all species excepting $A$. montensis, is harder to explain as a direct effect of rainfall, and could be a consequence of a trade-off with reproduction. Also congruent with this hypothesis is the fact that body condition index did not change over time in neither of the species. Apparently, energy provided by increased food availability was allocated to increase reproductive output and not accumulated as body reserves to improve body condition and survival prospects. Similar results were found in an experiment with food supplementation where mice also presented no variation of body condition (Días e Alonso 2003), as well as in other vertebrate groups like vipers (Baron et al 2013). 
Interestingly, the length of the time lag in the relationship between rainfall and survival rates seems to be associated with body size across the three rodent species for which there is evidence of a trade-off between survival and reproduction: A. montensis, D. sublineatus and E. russatus. Survival rates of $A$. montensis, the smallest species (mean weight \pm SD: $33.91 \mathrm{~g} \pm 8.13$ ) was related to rainfall of the same month, survival rates of $D$. sublineatus, which is intermediate in body size $(48.16 \mathrm{~g} \pm 9.09)$, was related to rainfall of the previous month, and survival rates of $E$. russatus, the largest species $(68.29 \mathrm{~g} \pm 13.06)$, was related to rainfall also of two months before. Although in the three species reproduction activity increases at the same time (in the period of highest rainfall, with no time lag), because the duration of the gestation is positively correlated with body size, the period of highest energy demands (lactation and weaning, Gittleman \& Thompson 1988), and thus lower survival, would occur at different times: the smaller the species, the shorter the gestation and the time lag between survival rate and rainfall.

Moreover, although most small rodents are known to be polyestrous species (Nowak 1991, Feliciano et al 2002, Graipel et al 2006, Antunes et al 2010), all of the several females we were able to monitor during their entire life had only one reproductive event (indicated by the record of swollen teats in the same individual up to three consecutive months). This indicates that it is beneficial for these species to invest more in reproduction and less in survival, thereby presenting an r-selection strategy common in rodents. Higher mortality due to reproduction might be caused by compensatory adjustments to divert more resources to reproduction, leading to changes in physiological regulations, physical activity and immunocompetence or a higher predation as a result of higher activity for an increased foraging to balance these increase in energy demands (Stearns 1992, Harshman \& Zera 2006, Speakman 2008).

It can be that the relationships of rainfall and either survival or reproduction are spurious, as density-dependence and predation patterns have not been evaluated in this study. Indeed, density-dependent processes could reduce survival even during periods of high food availability if 
carrying capacity is reached, but in this case a change in body condition should be observed. Predation is also a plausible explanation, but as exposed above increased predation does not necessarily exclude a trade-off between survival and reproduction. Thus, a likely explanation for the negative relationship between survival rates and rainfall is an indirect effect caused by tradeoffs with reproduction and we strongly advice that future studies consider this trade-off together with predation and density-dependent factors to understand the dynamics small rodents at Atlantic Forest. 
Table S1.1: Number of captures and individuals (in parentheses) in each capture grid (M1, M2, M3) and in total for all small mammals species captured at Morro Grande Forest Reserve. Due to the impossibility of separating the species Monodelphis americana and M. scalops in the field, individuals were counted together.

\begin{tabular}{|c|c|c|c|c|}
\hline Species & M1 & $\mathrm{M} 2$ & M3 & Total \\
\hline \multicolumn{5}{|l|}{ Rodents } \\
\hline Akodon montensis & $878(159)$ & $282(77)$ & $198(45)$ & $1358(281)$ \\
\hline Delomys sublineatus & $235(68)$ & $104(49)$ & $275(74)$ & $614(191)$ \\
\hline Euryoryzomys russatus & $159(47)$ & $197(58)$ & $169(46)$ & $556(151)$ \\
\hline Oligoryzomys nigripes & $188(110)$ & $155(108)$ & $134(90)$ & 477 (308) \\
\hline Thaptomys nigrita & $107(34)$ & $48(15)$ & $315(102)$ & $470(151)$ \\
\hline Brucepattersonius soricinus & $52(32)$ & $47(29)$ & $21(9)$ & $120(70)$ \\
\hline Sooretamys angouya & $20(12)$ & $3(3)$ & $22(12)$ & $45(27)$ \\
\hline Juliomys pictipes & $0(0)$ & $2(2)$ & $10(8)$ & $12(10)$ \\
\hline Bibimys labiosus & $4(2)$ & $1(1)$ & $0(0)$ & $5(3)$ \\
\hline Juliomys ossitenuis & $0(0)$ & $1(1)$ & $2(2)$ & $3(3)$ \\
\hline Nectomys squamipes & $3(1)$ & $0(0)$ & $0(0)$ & $3(1)$ \\
\hline Blarinomys breviceps & $0(0)$ & $1(1)$ & $1(1)$ & $2(2)$ \\
\hline Drymoreomys albimaculatus & $0(0)$ & $0(0)$ & $2(2)$ & $2(2)$ \\
\hline Oxymycterus judex & $1(1)$ & $0(0)$ & $0(0)$ & $1(1)$ \\
\hline Phyllomys nigrispinus & $0(0)$ & $1(1)$ & $0(0)$ & $1(1)$ \\
\hline \multicolumn{5}{|l|}{ Marsupials } \\
\hline Marmosops incanus & $41(17)$ & $150(44)$ & $39(13)$ & $230(74)$ \\
\hline Didelphis aurita & $10(5)$ & $22(7)$ & $12(4)$ & $44(16)$ \\
\hline Monodelphis americana, M. scalops & $0(0)$ & $4(3)$ & $35(26)$ & $39(29)$ \\
\hline Monodelphis iheringui & $17(12)$ & $10(7)$ & $12(8)$ & $39(29)$ \\
\hline Gracilinanus microtarsus & $6(4)$ & $7(7)$ & $10(10)$ & $23(21)$ \\
\hline Marmosops paulensis & $0(0)$ & $0(0)$ & $22(8)$ & $22(8)$ \\
\hline Marmosa paraguayana & $5(2)$ & $7(1)$ & $1(1)$ & $13(4)$ \\
\hline Monodelphis new sp. & $0(0)$ & $1(0)$ & $11(9)$ & $12(9)$ \\
\hline Total & $1726(506)$ & $1043(415)$ & $1291(470)$ & 4065 (1380) \\
\hline
\end{tabular}



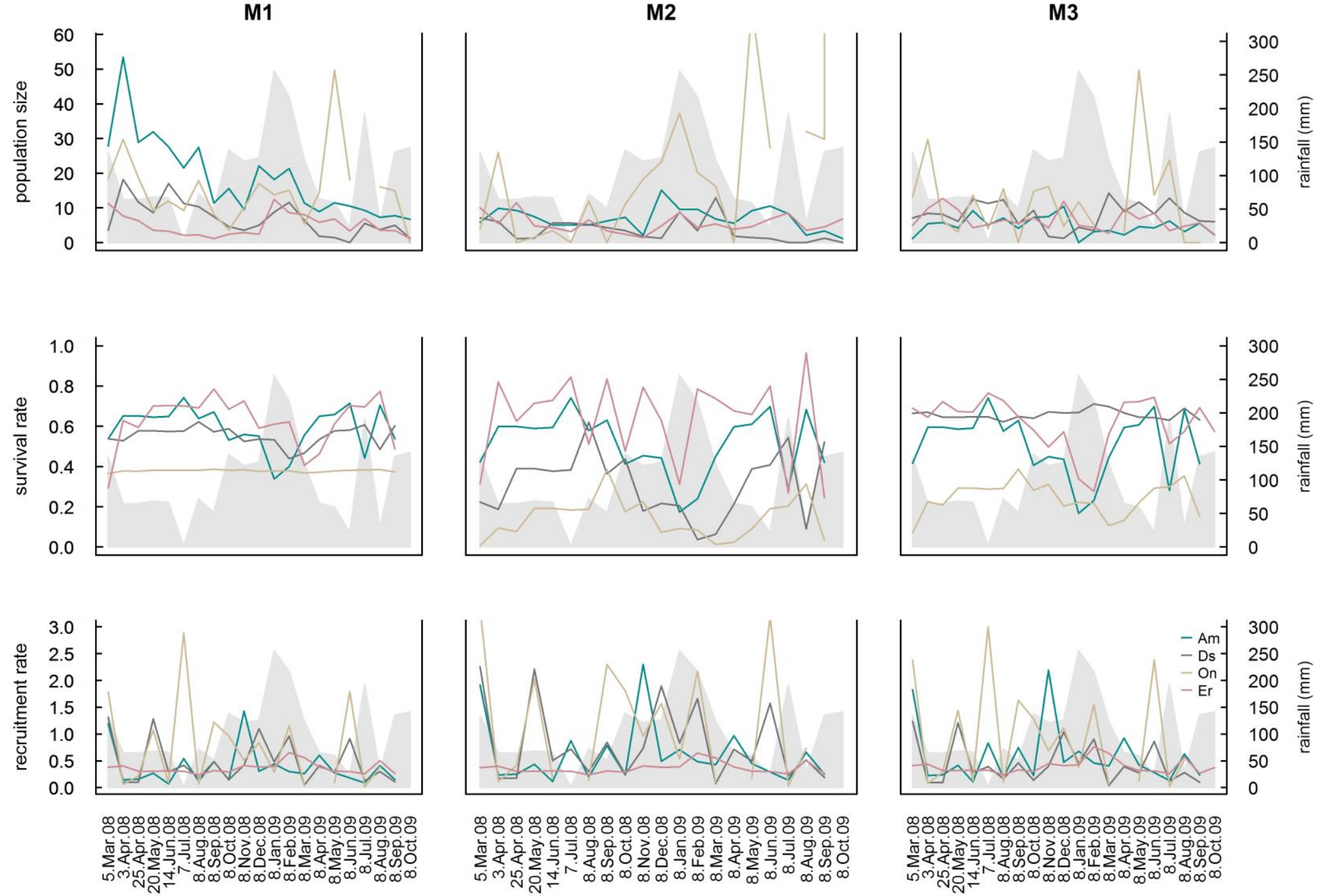

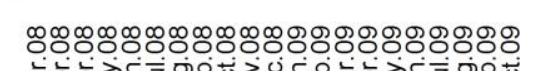

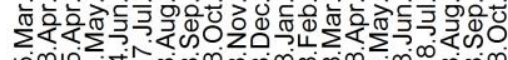

Figure S1.1: Temporal variation of population size, survival rate and recruitment rate for the rodents species (Am: Akodon montensis, Ds: Delomys sublineatus, Er: Euryoryzomys russatus and On: Oligoryzomys nigripes) in each grid (M1, M2, M3) of the Morro Grande Forest Reserve. Gray shadow represents the amount of monthly rainfall (secondary $y$-axis). Values of the parameters come from the model selected for each species. 


\section{Capítulo 2}

\section{Timing and triggering of reproductive activity in Atlantic Forest marsupials}
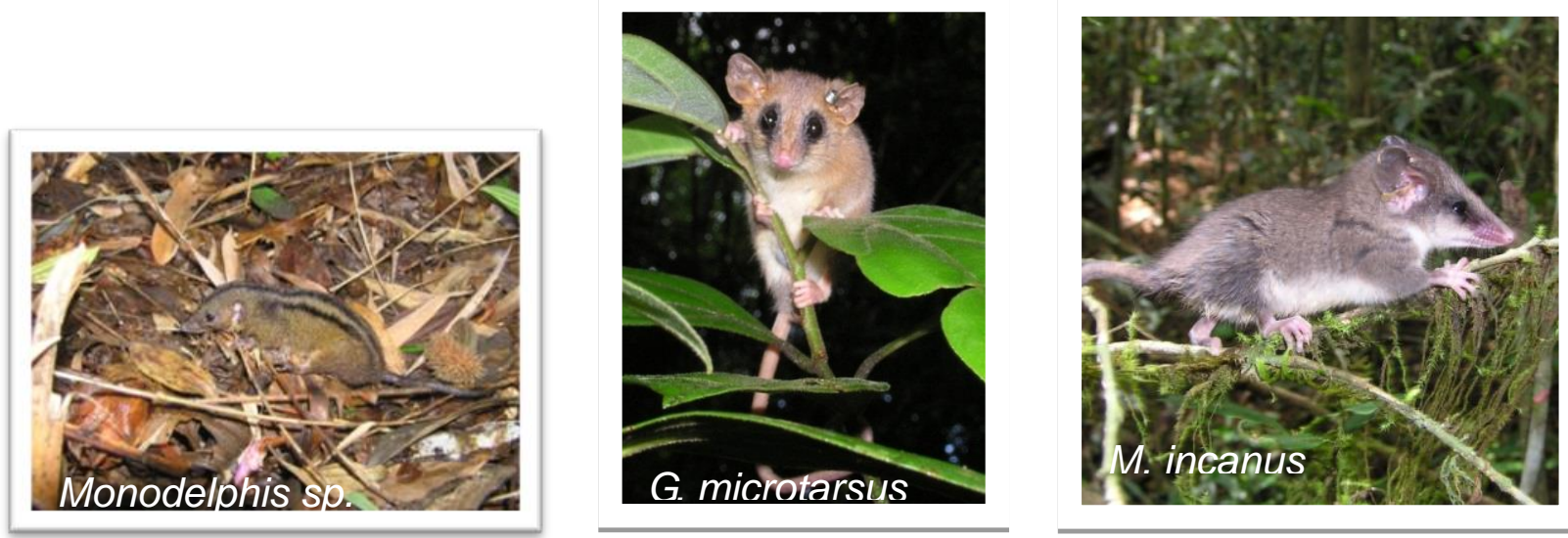


\title{
CAPÍtULO 2
}

\section{TIMING AND TRIGGERING OF REPRODUCTIVE ACTIVITY IN ATLANTIC FOREST MARSUPIALS}

\author{
CAMILA S. BARROS ${ }^{1}$, THOMAS PÜTTKER ${ }^{2}$ \& RenATA PARDINI ${ }^{2}$ \\ ${ }^{1}$ Departmento de Ecologia e ${ }^{2}$ Departmento de Zoologia, Instituto de Biociências, Universidade de \\ São Paulo, Rua do Matão, 321, trav. 14, 05508-900, São Paulo, SP, Brazil.
}

\section{Abstract}

Seasonal reproduction is a widespread strategy in marsupials, leading to the production of juveniles when food availability is high, maximizing offspring survival. In Australian marsupials, reproduction is commonly synchronous among co-occurring species, the onset of reproduction being triggered by photoperiodic cues, and a partial semelparity, with high mortality of males after reproduction, is a common pattern in a subset of these species. For Neotropical marsupials, however, despite some evidence of a seasonal synchronous reproduction, environmental triggers of reproduction have been poorly studied and semelparity has been convincingly described in a few species. Using a capture-recapture dataset, comprising three two-ha grids sampled for almost two years, we aim to contribute to the understanding of the timing and triggering of reproductive activity and of semelparity among co-occurring marsupials in the Atlantic forest. We evaluated which environmental cues (rainfall, photoperiod and temperature) best explains the age structure of the populations of five species, and assessed if survival rate is affected by sex and reproductive period in the population of the most common species. Our results indicate that reproduction in small-sized, Atlantic Forest marsupials is seasonal, with juveniles being born and lactation occurring in the period of highest food availability, the warm-wet season. Reproduction onset seems to be synchronous among species and driven by photoperiod cues. Semelparity is probably 
the cause of a high population turnover in $M$. incanus, and also in co-occurring small-sized marsupials.

Keywords: breeding season, CJS models, food availability, Gracilinanus, Monodelphis, Marmosops, opossum, reproduction onset, survival rates.

\section{Introduction}

A widespread reproductive strategy in marsupials is the coupling of the production of juveniles with the period of maximum offspring survival (Tyndale-Biscoe 2005). Given the high energetic demands of reproduction, seasonal variation in food availability is supposed to be the underlying factor associated with reproduction in most marsupials (McAllan 2003, Cáceres 2012). As the period of highest energetic costs for female marsupials is lactation (Isaac \& Johnson 2005), reproductive success would be higher if this phase of reproduction coincides with the period of highest food availability, which is usually the high rainfall period of the warm-wet season (Bergallo \& Magnusson 1999, Leiner et al 2008). Moreover, the beginning of reproduction is commonly synchronous among co-occurring marsupial species, and starts some time before the period of highest food availability (McAllan 2003). To optimize reproduction, an early onset of reproduction would be beneficial as it would allow for more than one litter per reproductive period (TyndaleBiscoe 2005, Astúa \& Geise 2006).

While the environmental proxy triggering, as well as the timing, of marsupial reproduction has been the focus of a long-standing debate, photoperiodic cues (either photoperiod length or the rate of change of photoperiod) seem to be widespread in Australian marsupials (Goldman 2001, Tyndale-Biscoe 2005, McAllan et al 2006, Naylor et al 2008). Instead, reproduction in Neotropical marsupials has been shown to be correlated directly with rainfall, a proxy for food availability (Bergallo 1994, Gentile et al 2000, Passamani 2000, Graipel et al 2006, D’Andrea et al 2007, Kajin 
et al 2008, Bonecker et al 2009). However, two studies presented evidence of photoperiod as a cue for reproduction also in this group (Monodelphis domestica, Cerqueira \& Bergallo 1993, Marmosops paulensis, Leiner et al 2008). On the other hand, since temperature affects the activity of marsupials, with some species entering torpor under extreme high temperature and low rainfall (Bozinovic et al 2005) or extremely low temperatures (Geiser and Baudinette 1987, Bozinovic et al 2004), temperature is also a plausible candidate for a trigger of reproduction in these animals.

In small short-lived marsupials in particular, as the chance of future reproduction declines as the animal approaches the end of its life, terminal investment theory predicts a higher investment in reproduction, which would then lead to a trade-off between reproduction and survival (Isaac \& Johnson 2005). Extreme physiological costs of reproduction that can cause this trade-off include compensatory adjustments to divert resources into reproduction, as reductions in hormonal and thermoregulation and immunocompetence, which lead to higher mortality after reproduction (Oackwood et al 2001, Boonstra 2005, Speakman 2008). Thus, another common reproductive pattern among marsupials is semelparity, defined as high adult mortality after the breeding season, such that each individual can take part in only one reproductive event (Cole 1954). Although not common among mammals (Oakwood et al. 2001), semelparity is widespread in a subset of Australian marsupials (Oakwood et al 2001, McAllan 2003, McAllan et al 2006), for which only males present this pattern, while females reproduce more than once (Fisher and Blomberg 2011). In contrast, evidence of semelparity has been found in only four Neotropical marsupials (Marmosops paulensis, Leiner et al 2008; Marmosops incanus, Lorini et al 1994; Monodelphis dimidiata, Baladrón et al 2012), and for only one of them semelparity is observed in males only (Gracilinanus microtarsus, Martins et al 2006).

Here we aim to contribute to the understanding of the timing and triggering of reproductive activity, and evaluated the existence of semelparity, in Atlantic Forest marsupials. Using capture- 
recapture data from three 2 ha grids over almost two years, we evaluate which environmental cues (rainfall, photoperiod and temperature) best explains the age structure of the populations of five co-occurring species, and assessed if survival rate is affected by sex and reproductive timing in the population of the most common species.

\section{Material and methods}

\section{Studied species}

We captured nine species of marsupials in our grids, from the commonest to the rarest: Marmosops incanus, Didelphis aurita, Monodelphis americana, Monodelphis scalops, Monodelhpis iheringi, Gracilinanus microtarsus, Marmosops paulensis, Marmosa paraguayana and Monodelphis sp. nova (Table 2.1). Excepting $D$. aurita, a medium-sized species, all other are small-sized marsupials. Three species (genus Monodelphis) are terrestrial/ semi-fossorial and five are scansorial (Table 2.1). Most species have an insectivore-omnivore diet (Table 2.1).

Due to the impossibility of separating the species Monodelphis americana and M. scalops in the field, individuals were counted together. For the analysis of reproduction timing and triggering, we considered the five most common species (with more than 20 captures), excluding $D$. aurita since no adults were captured given the small size of our traps (Table 2.1). For the analysis of semelparity, capture-recapture data was enough only for the most common species, Marmosops incanus.

Study site

We collect data at the Morro Grande Forest Reserve (2339'-2348'S, 4701'-465' W, Cotia, São Paulo, Fig. 2.1), a 9400 ha continuous forest connected to the largest tract of remaining Atlantic forest in Brazil. It is covered by Lower Montane Atlantic Rain Forest in different regeneration stages (Metzger et al. 2006). The altitude in the region varies from 850 to $1100 \mathrm{~m}$ above sea level. 
Mean maximum temperature is $27^{\circ} \mathrm{C}$ and mean minimum temperature is $11^{\circ} \mathrm{C}$. Mean annual rainfall is $1339 \mathrm{~mm}$, and the warm-wet season is from September to March (Metzger et al. 2006).

Data collection

We set three 2-ha trapping grids (100 m x $200 \mathrm{~m}$ ) at least $2 \mathrm{~km}$ apart at the Reserve (Fig. 2.1). Each grid comprised 11 100-m lines, 20 m apart from each other, each composed of 11 trap stations every $10 \mathrm{~m}$. Six alternated lines had only 11 Sherman traps $(37.5 \times 10.0 \times 12.0 \mathrm{~cm}$ or 23.0 $\times 7.5 \times 8.5 \mathrm{~cm}$ ) on the ground. The other five lines had, besides the Sherman traps, 11 pitfall traps (60 L buckets buried at the ground, connected by $50-\mathrm{cm}$ high drift-fences) at the same trap stations, totaling 121 Sherman traps and 55 pitfall traps per grid. In order to reduce animals deaths at pitfall traps we (1) made holes at the bottom of the buckets and caved a deeper hole to buried them in order to prevent accumulation of rainwater, (2) placed a piece of styrofoam at the bottom of the buckets for fluctuation in the event of flooding, (3) placed food in the bucket for feeding the animals at night, and (4) put a cover at 50-cm from the ground, working as an umbrella. Traps received daily baits made of a mashed banana, cornmeal, peanut butter and sardines.

We performed 21 5-night capture sessions between March 2008 and October 2009. Interval between sessions varied from 16 to 30 days (mean of 23.4 days). Captured individuals were marked with aluminum tags with unique codes, allowing individual recognition. For each capture we recorded the species, weight, sex (by external characteristics). Age classes were determined by tooth eruption (Macedo et al 2006). Reproductive activity in females was determined by pregnancy or the presence of swollen teats. Voucher specimens of all species were collected in a pilot sample, identified by experts, and are kept in the Department of Zoology, University of Sao Paulo. 
Photoperiod in São Paulo varies from 10h40min (640min) in June to $13 \mathrm{~h} 35 \mathrm{~min}$ (815min) in December (Anuário do Observatório Nacional 2008, 2009). Mean monthly rainfall was obtained from SAPESP, the government agency who manages the Morro Grande Forest Reserve. This agency does not have records of monthly temperature, thus we used data from Ibiúna, a neighbor city where another government agency CIIAGRO collects data (http://www.ciiagro.sp.gov.br/ciiagroonline in 14.Nov.2012).

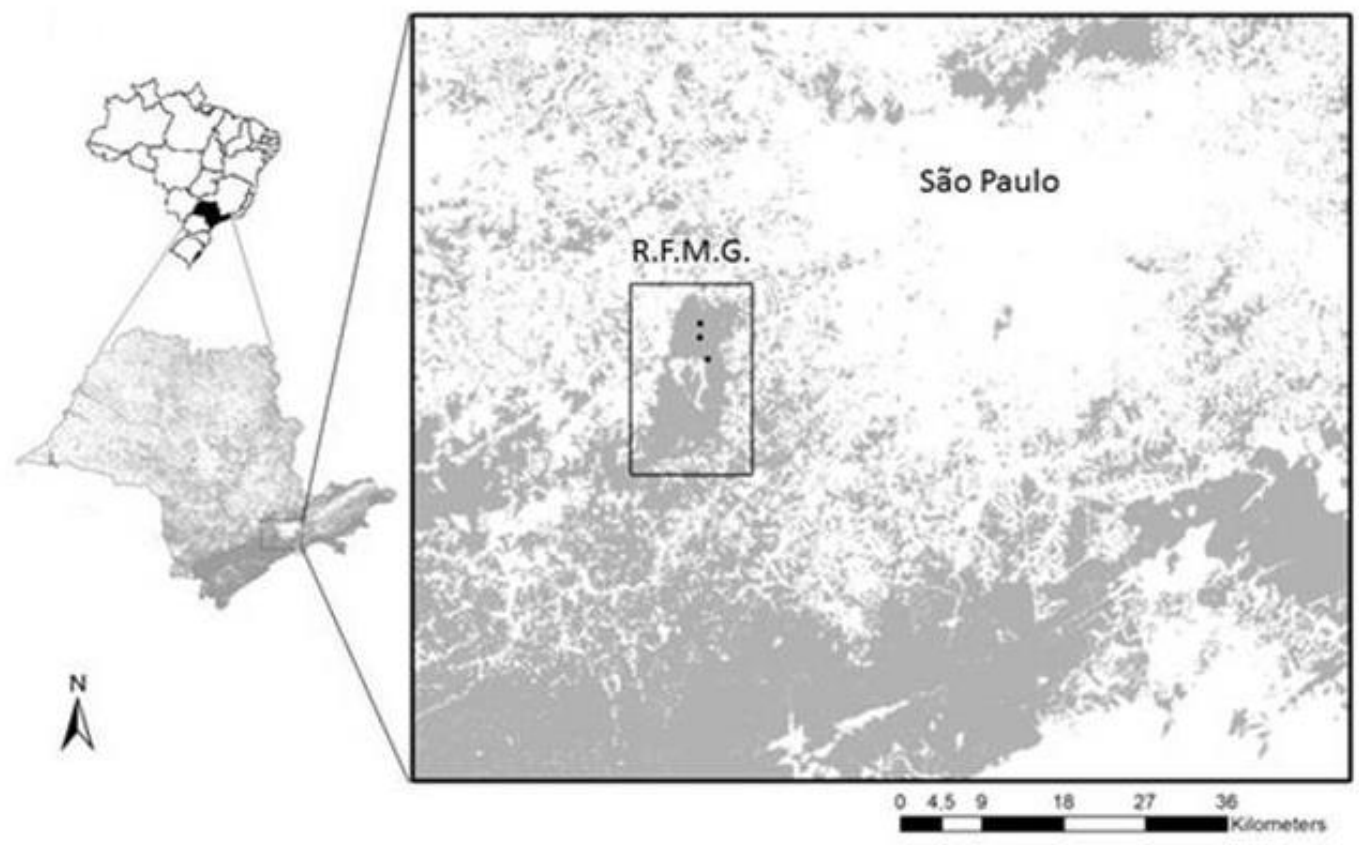

Figure 2.1: Morro Grande Forest Reserve (R.F.M.G.) in São Paulo State, Brazil near to São Paulo City. Black dots represent the 2-ha trapping grids (M1, M2 and M3). Gray areas represent forest remnants.

\section{Data analysis}

Our analyses were based on two different model selections, for both of which the plausibility of candidate models was assessed using Akaike's Information Criterion corrected for small samples (AICc, Williams et al. 2002, Burnham \& Anderson 2002). AICc values of each model were subtracted from the AICc value of the most plausible model $(\Delta \mathrm{i})$, and models were considered equally plausible with $\Delta i \leq 2$ (Burnham \& Anderson 2002). To distinguish among equally plausible 
models we considered the most parsimonious model, the one with the lowest number of parameters (Lebreton et al 1992).

Reproductive timing and triggering: Because the number of reproductive activity females was low for all species, we used the distributions of individuals across age classes to access the timing of reproduction (e.g. Bergallo 1994, Feliciano et al 2002, Gentile et al 2000, D’Andrea et al 2007, Barros et al 2008,). Age classes were based on the molar teeth eruption pattern (only M1 or M1 and M2 erupted - juveniles; M3 erupted - subadults; M4 erupted - adults) as described by Macedo et al (2006). The dependent variable was then the proportion of non-reproductive animals (juveniles) relative to the total number of individuals captured modeled as a binomial variable. We considered together all five marsupial species with more than 20 captures (excluding $D$. aurita). To evaluate if reproductive activity is seasonal and identify its environmental trigger, we run a model selection comparing a set of candidate Generalized Linear Mixed-Effects models (GLMM), allowing the incorporation of species dependency through the use of random intercept and slope factors (Bolker et al 2008, Zuur et al 2009). Fixed factors were monthly rainfall, mean monthly minimum temperature, mean monthly photoperiod and rate of change of photoperiod (mean monthly difference in seconds of photoperiod from one day to the next) with time lags up to two months. Different types of environmental variables (rainfall, temperature, and both measures of photoperiod) were not included together in the same model given the high correlation among them $\left(R^{2}\right.$ varying from $0.44-0.46$, all $p<0.001$; Fig S2.1). However, for each type of environmental variables, the different time lags were included both in simple and in additive models. The candidate set included also a constant model (with no fixed factor) and a temporal model with months as a fixed factor. As previous analyses showed no variation among the three capture grids, we analyzed data from the three grids together. All analyses were run in program R, version 2.13.0 ( $R$ Development Core Team, 2011) using Imer4 package (Bates et al 2011). 
Semelparity: To evaluate the occurrence of semelparity, i.e. if survival rates is affected by sex and reproductive timing, we run a capture-recapture analysis using Comarck-Jolly-Seber model (Willians et al 2002) on Program Mark version 6.1 (White \& Burnhan 1999). For this analysis we used only the data from the species with enough captures, Marmosops incanus. As in semelparous animals the period of high adult mortality (low survival rate) is just after mating (Boonstra 2005), we divided our dataset in two periods, following Martins et al (2006): premating period - when the population has non-reproductive animals (juveniles, January to May), and a mating period - when the population does not have non-reproductive animals (June to December). The candidate set included a constant model (survival rates with no co-variables), two simple models in which survival rate is a function of sex or mating periods, and an additive and interaction models with these variables.

\section{Results}

In a total of 55440 trapping-nights, we obtained 422 captures of 188 individuals of nine marsupial species (Table 1). No animals present in the first year were recaptured in the second year (Fig 2.2).

Table 2.1: Number of captures and individuals (in parentheses) for marsupial species captured at the Morro Grande Forest Reserve. Due to the impossibility of separating the species Monodelphis americana and $M$. scalops in the field, individuals were counted together. Diet and habit followed Paglia et al 2012.

\begin{tabular}{lccc}
\hline Species & Captures (individuals) & Diet & Habit \\
\hline Marmosops incanus & $230(74)$ & insetivorous/onmivorous & scansorial \\
Didelphis aurita & $44(16)$ & frugivorous/onivorous & scansorial \\
Monodelphis americana, M. scalops & $39(29)$ & insetivorous/onmivorous & terrestrial \\
Monodelphis iheringui & $39(27)$ & insetivorous/onmivorous & terrestrial \\
Gracilinanus microtarsus & $23(21)$ & insetivorous/onmivorous & scansorial \\
Marmosops paulensis & $22(8)$ & insetivorous/onmivorous & scansorial \\
Marmosa paraguayana & $13(4)$ & insetivorous/onmivorous & scansorial \\
Monodelphis sp. nova & $12(9)$ & -- & terrestrial \\
Total & $\mathbf{4 2 2 ( 1 8 8 )}$ & & \\
\hline
\end{tabular}


M. incanus

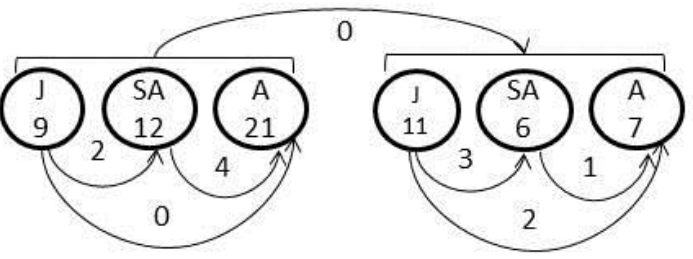

M. americana/scalops

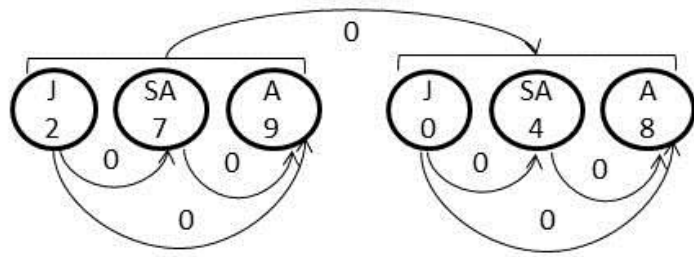

G. microtarsus

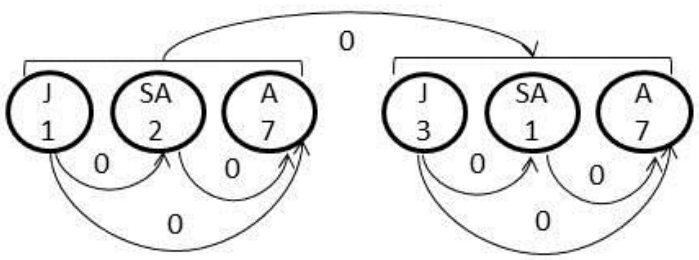

D. aurita

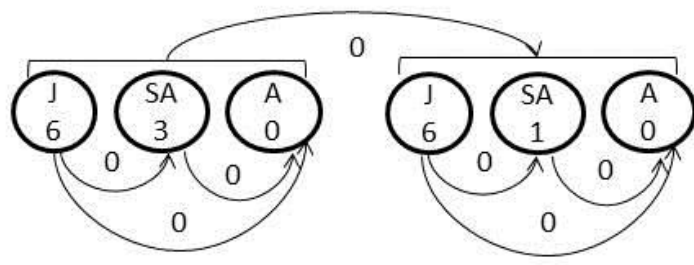

M. iheringi

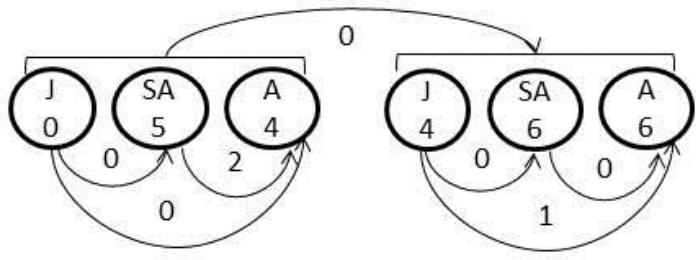

M. paulensis

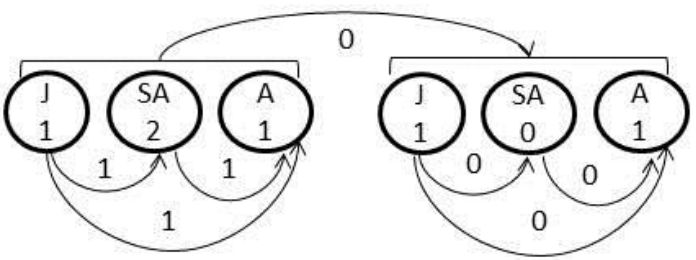

Figure 2.2: Number of individuals in each age class (J- juvenile, SA- subadult, A-adult) and the number of those that were recaptured in another age class in each year for six marsupial species at the Morro Grande Forest Reserve.

Reproductive timing: In all species, juveniles occur only between January and May, in the late wet- early dry-season (Fig 2.3). We could not evaluate D. aurita in detail, as we captured only juveniles and subadults of this species, but juveniles of this species also occur concentrated in time (from December to April).

Reproductive triggering: The only selected model indicates that photoperiod with one month time lag is the most important determinant of the appearance of juveniles (Table 2.2, Fig 2.4). All models containing photoperiod as a co-variable were among the first-ranked, while the constant and temporal models were among the worst models. Photoperiod with one month time lag had a positive relationship with the proportion of juveniles for most species (Fig 2.4). The best models containing rainfall and minimum temperature as co-variables were the simple models with no time lag, and although worse than all models containing photoperiod, were much better than the 
reference model (Table 2.2). For both variables, the relationship with the proportion of juveniles is also positive for most species (Fig 2.4).

Semelparity: Three models were selected to describe the variation in the survival rates of $M$. incanus (Table 2.3). The most plausible model considers a constant capture probability and survival rates varying as an additive function of both sex and mating period. The other two selected models also consider survival rates as an additive function of these two variables, and capture probability as a simple function of either mating period or sex (Table 2.3). Males present survival rates lower than females; and for both sexes, survival rates are lower during the mating period (Fig. 2.5).

Table 2.2: Results of the selection of models of the proportion of juveniles as a function of environmental cues triggering reproduction in four marsupial species at the Morro Grande Forest Reserve. pho=mean monthly photoperiod, $\mathrm{ppt}=$ monthly rainfall, Rpht=rate of change for photoperiod, temp=mean monthly minimum temperature. Numbers indicate the time lag in months. $\Delta_{i}$ : difference of AICc value to the best model, $\omega_{\mathrm{i}}$ : Akaike weight, $\mathrm{K}$ : number of parameters. Most plausible model is highlighted in bold. In all models, species were considered intercept and slope random factors.

\begin{tabular}{lccc}
\hline & $\mathrm{K}$ & $\Delta \mathrm{i}$ & $\omega \mathrm{i}$ \\
\hline pht1 & $\mathbf{0}$ & $\mathbf{5}$ & $\mathbf{0 . 7 5}$ \\
Rpht+Rpht1 & 3.0 & 9 & 0.17 \\
pht 2 & 6.2 & 5 & 0.03 \\
pht+pht1 & 7.6 & 9 & 0.02 \\
pht1+pht2 & 7.8 & 9 & 0.02 \\
Rpht1+Rpht2 & 7.9 & 9 & 0.01 \\
pht & 10.7 & 5 & 0.00 \\
temp & 11.5 & 5 & 0.00 \\
ppt & 16.7 & 5 & $<0.001$ \\
temp+temp1 & 19.4 & 9 & $<0.001$ \\
ppt+ppt1 & 24.8 & 9 & $<0.001$ \\
temp1 & 36.6 & 5 & $<0.001$ \\
temp1 & 44.4 & 9 & $<0.001$ \\
ppt1 & 44.7 & 5 & $<0.001$ \\
temp2 & 45.0 & 5 & $<0.001$ \\
ppt2 & 46.0 & 5 & $<0.001$ \\
ppt1+ppt2 & 47.3 & 9 & $<0.001$ \\
cte & 48.9 & 2 & $<0.001$ \\
Rpht1 & 49.6 & 5 & $<0.001$ \\
Rpht2 & 50.4 & 5 & $<0.001$ \\
temporal & 1139.0 & 230 & $<0.001$ \\
\hline & & &
\end{tabular}


Table 2.3: Results of the selection of capture-recapture models of survival rates as a function of sex and mating period for Marmosops incanus at the Morro Grande Forest Reserve. $\Delta_{\mathrm{i}}$ : difference of AICc value to the best model, $\omega_{i:}$ Akaike weight, $\mathrm{K}$ : number of parameters. Most plausible model is highlighted with bold letters. $\phi=$ survival, $p=$ capture probability.

\begin{tabular}{|c|c|c|c|c|}
\hline Model & & $\mathrm{K}$ & $\Delta \mathrm{i}$ & $\omega i$ \\
\hline$\phi$ (sex+period) & p(.) & 4 & 0 & 0.23 \\
\hline$\phi($ sex+period) & $\mathrm{p}$ (period) & 5 & 1.1 & 0.13 \\
\hline$\phi($ sex+period) & $\mathrm{p}(\mathrm{sex})$ & 5 & 1.5 & 0.11 \\
\hline$\phi(\operatorname{sex})$ & $\mathrm{p}()$. & 3 & 2.0 & 0.09 \\
\hline$\phi($ sex+period $)$ & $p($ sex+period $)$ & 6 & 2.6 & 0.06 \\
\hline$\phi($ sex*period) & $\mathrm{p}$ (period) & 6 & 3.2 & 0.05 \\
\hline$\phi(\operatorname{sex})$ & $\mathrm{p}(\mathrm{sex})$ & 4 & 3.3 & 0.04 \\
\hline$\phi($ sex*period) & $p(\operatorname{sex})$ & 6 & 3.5 & 0.04 \\
\hline$\phi(\operatorname{sex})$ & $\mathrm{p}$ (period) & 4 & 3.8 & 0.03 \\
\hline$\phi($ sex*period) & $\mathrm{p}()$. & 5 & 3.8 & 0.03 \\
\hline$\phi($ period $)$ & $p($ sex+period $)$ & 5 & 4.2 & 0.03 \\
\hline$\phi($ period $)$ & $\mathrm{p}(\mathrm{sex})$ & 4 & 4.4 & 0.03 \\
\hline$\phi()$. & $\mathrm{p}(\mathrm{sex})$ & 3 & 4.6 & 0.02 \\
\hline$\phi($ sex*period) & $\mathrm{p}($ sex+period $)$ & 7 & 4.8 & 0.02 \\
\hline$\phi(\operatorname{sex})$ & $p($ sex+period $)$ & 5 & 5.5 & 0.01 \\
\hline$\phi($ sex+period) & $\mathrm{p}\left(\right.$ sex*period $\left.^{*}\right)$ & 7 & 5.9 & 0.01 \\
\hline$\phi($ period $)$ & $\mathrm{p}$ (period) & 4 & 6.0 & 0.01 \\
\hline$\phi($ period $)$ & $\mathrm{p}()$. & 3 & 6.1 & 0.01 \\
\hline$\phi($ period $)$ & $\mathrm{p}(\text { sex*period })^{*}$ & 6 & 6.2 & 0.01 \\
\hline$\phi()$. & $\mathrm{p}()$. & 2 & 6.4 & 0.01 \\
\hline$\phi()$. & $p($ sex+period $)$ & 4 & 6.7 & 0.01 \\
\hline$\phi$ (sex*period) & $\mathrm{p}($ sex*period) & 8 & 7.1 & 0.01 \\
\hline$\phi(\operatorname{sex})$ & $\mathrm{p}($ sex*period) & 6 & 7.5 & 0.01 \\
\hline$\phi()$. & $\mathrm{p}$ (sex*period) & 5 & 8.0 & $<0.001$ \\
\hline$\phi()$. & $\mathrm{p}$ (period) & 3 & 8.5 & $<0.001$ \\
\hline
\end{tabular}


Marmosops incanus

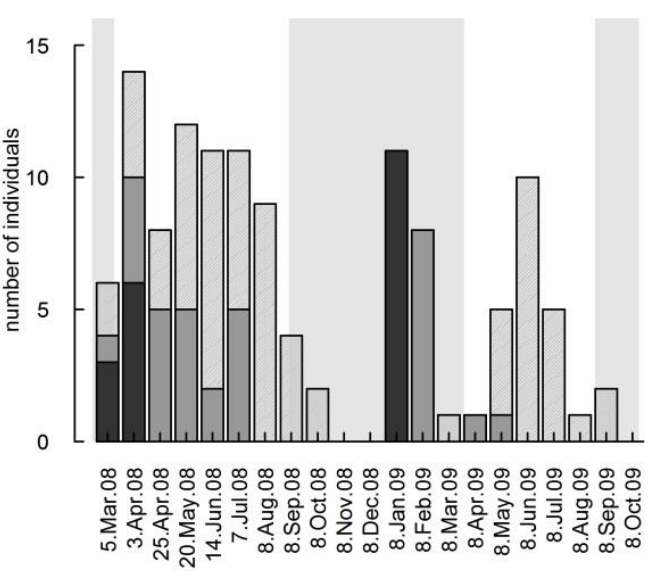

Monodelphis iheringi

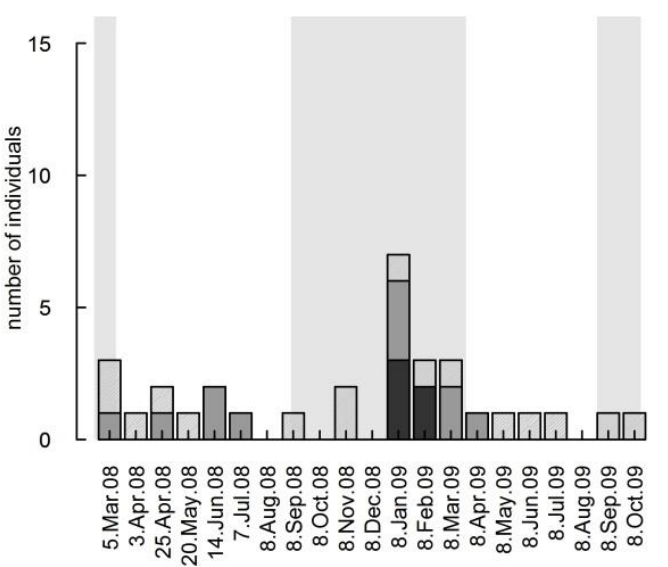

Didelphis aurita

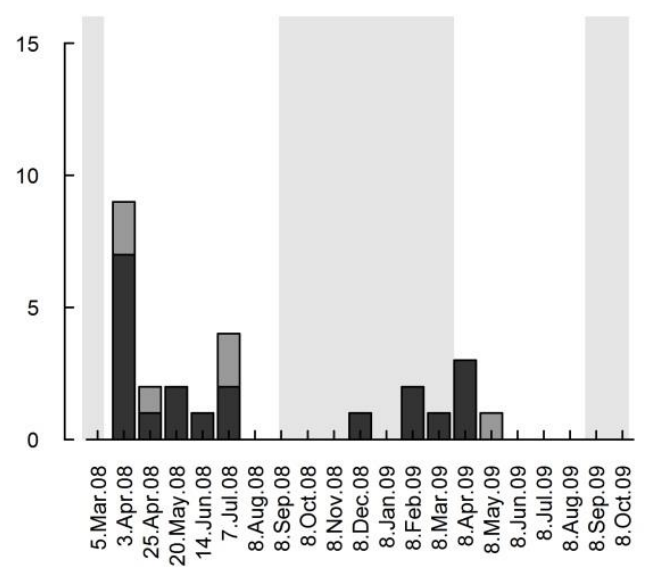

Gracilinanus microtarsus

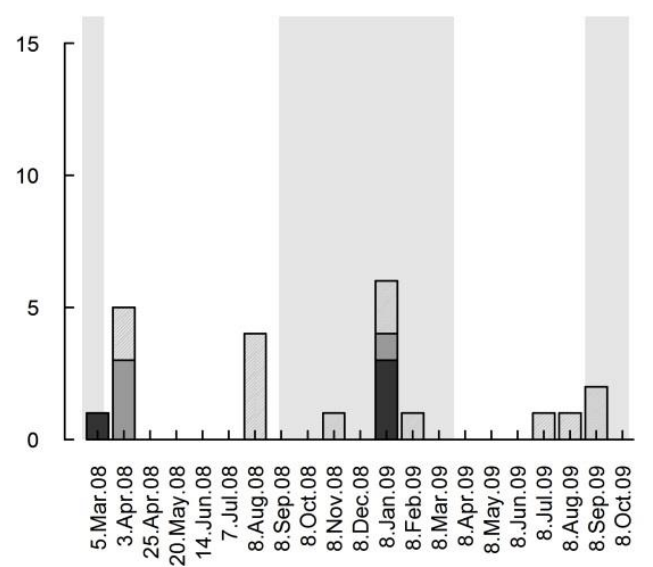

M. americana/scalops

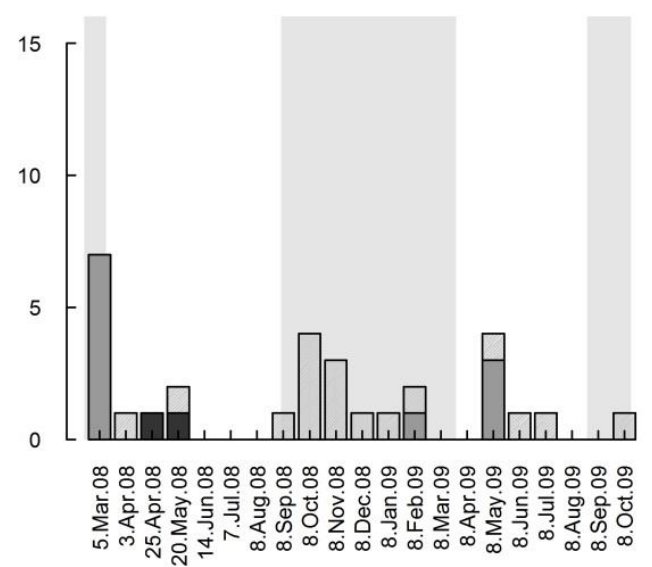

Marmosops paulensis

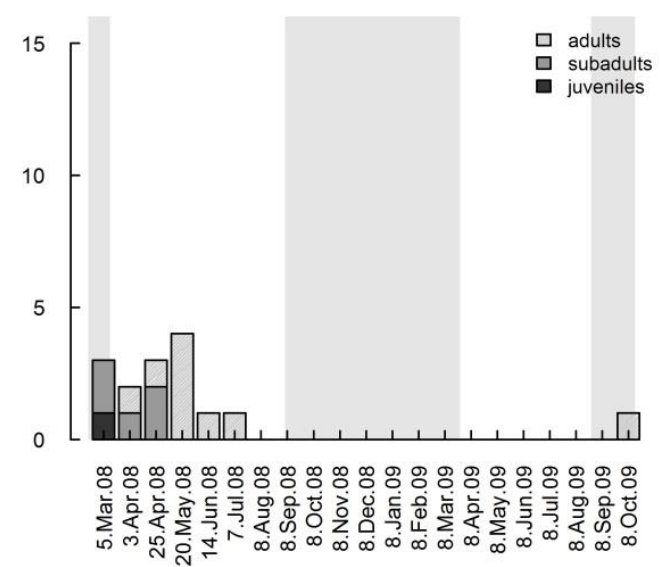

Figure 2.3: Age distribution in the population of marsupials at the Morro Grande Forest Reserve during March 2008 and October 2009 . Gray shadow represents the warm-wet season. 

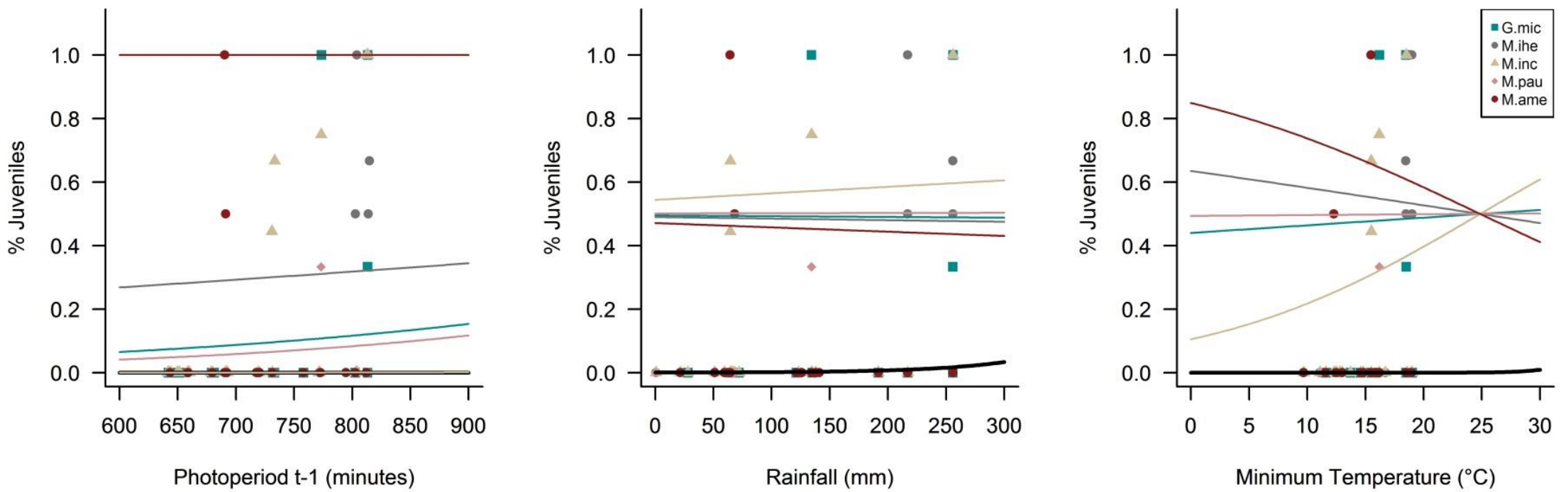

Figure 2.4: Proportion of juveniles as a function of mean monthly photoperiod (time lag of one month), monthly rainfall and mean monthly minimum temperature at the Morro Grande Forest Reserve. Black line represents the general model and colored lines represents the random factors of each species (G.mic: Gracilinanus microtarsus; M.ihe: Monodelphis iheringi; M.inc: Marmosops incanus; M.pau: Marmosops paulensis; M.ame: Monodelphis americana + M. scalops). 


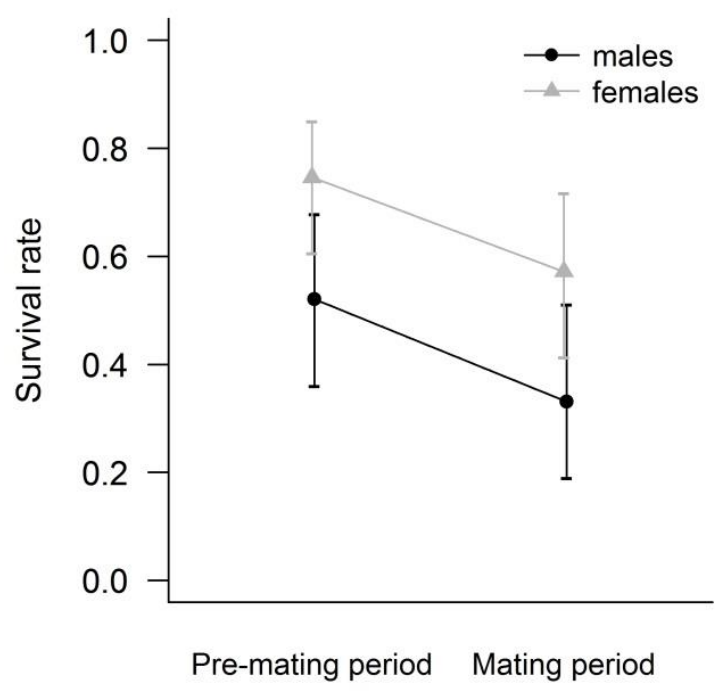

Fig 2.5: Survival rates ( \pm SE) of Marmosops incanus at the Morro Grande Forest Reserve as a function of sex and mating period, as estimated by the best capture-recapture model in Table 3.

\section{Discussion}

Reproductive timing: Our results confirm that reproduction in Atlantic forest marsupials is seasonal, and synchronous among small-sized co-occurring species (Bergallo 1994, Gentile et al 2000, Passamani 2000, Graipel et al 2006, D’Andrea et al 2007, Kajin et al 2008, Bonecker et al 2009). As young individuals of small-sized marsupials begin to be independent of their mothers at about one to two months after they are born (after a 15 days pregnancy) (Tyndale-Biscoe 2005), we can estimate that the onset of the breeding season starts around October-November (two to three months before juveniles appear), lasting till February-March (two to three months before juveniles disappear), in the warm-wet season. Lactation thus occurs within this period, which is considered of higher food availability, especially for insectivore species in the Atlantic forest (Bergallo \& Magnusson 1999, Leiner et al 2008). Indeed, studies with small-sized marsupials showed that reproduction is seasonal and concentrates during warm-wet season in this biome (Gracilinanus microtarsus, Martins et al 2006; Gracilinanus agilis, Passamani et al 2000; Marmosa 
paraguayana, Barros et al 2008; Marmosops incanus, Lorini et al 1994, Passamani 2000; Marmosops paulensis, Leiner et al 2008).

It has been suggested, on the other hand, that larger opossums are able to maximize their reproductive success by having a continuous reproduction and these patterns may be a consequence a more flexible diet (Barros et al 2008, Díaz \& Flores 2008). The temporal distribution of juveniles and sub-adults of $D$. aurita in our study site indicate that the reproductive period of this larger opossum is indeed longer than that for co-occurring smaller species, but also seasonal.

Reproductive triggering: As the onset of reproduction seems to be synchronous among the smallsized marsupials in this study, there should be a common environmental trigger for the reproduction of these animals. We evaluate four possible triggers, and the proportion of juveniles was best explained by the photoperiod with one month time lag. Despite the strong correlation among photoperiod, rainfall and minimum temperature, all models with temperature or rainfall had a much lower weight of evidence, and the best models with these co-variables were those with no time lag. This indicates that, as for Australian marsupials (Goldman 2001, Tyndale-Biscoe 2005, McAllan et al 2006, Naylor et al 2008), photoperiod is the trigger for the reproduction of small-sized Neotropical marsupials, resulting in the concentration of juveniles during the months of highest temperature, rainfall and food availability.

Day light is known to induce the physiological changes necessary for reproduction in Australian marsupials (Tyndale-Biscoe 2005). Experimental evidence demonstrated that female Antechinus flavipes under artificial, unchanging 12L:12D do not enter estrus, whereas increasing daily day length in minutes triggered the breeding activity of females (McAllan \& Geiser 2006). Another study showed that these responses were related to the rate of change instead of the absolute length of photoperiod (McAllan et al 2006). Although experimental physiological evidence or observational tests of different cues are not available for Neotropical marsupials, field data on 
reproductive activity is congruent with the idea of photoperiod as the trigger of the reproduction in these species. Females of G. microtarsus were reproductive active from the end of dry season, suggesting an early onset of reproduction in relation to the wet season (Martins et al 2006b), and females reproductive activity of $M$. paulensis occurred during the period of longer day lengths (Leiner et al 2008). The reproduction of Monodelphis domestica at northeast of Brazil followed the mean curve of rainfall for the region rather than the current rainfall, which also indicates that reproduction could be determined by photoperiod rather than rainfall itself (Cerqueira \& Bergallo 1993).

Semelparity: Our results indicate that $M$. incanus is a semelparous species, and suggest that this may also be the pattern for other co-occurring small-sized marsupials for which data was not sufficient for estimating survival rates. Survival rates of $M$. incanus were lower during the mating period for both sexes, a semelparous pattern. A decreased abundance from May onwards, after the disappearance of juveniles, culminating with no captures of $M$. incanus between November and December, and the reappearance of adults in the population only in March, reinforce this pattern. A similar pattern of low abundance between September and November was also found in the semelparous G. microtarsus (Martins et al 2006b). Moreover, no animal captured in the first year was recaptured in the second year, not only in $M$. incanus but also in all studied small-sized marsupial, indicating a high population turnover characteristic of semelparous species.

Although semelparity has not been previously studied in the field in populations of $M$. incanus, an analysis of museum specimens from five Brazilian states (southeastern and south) had already suggested a semelparous pattern in this species, as there were no adults collected between February and March (Lorini et al 1994), as observed in our study. There is also evidence of semelparity in the literature for a congeneric species, Marmosops paulensis, and for another small-sized Neotropical marsupial, Monodelphis dimidiata, as for both species there was an annual replacement of generations for both sexes (Leiner et al 2008, Baladrón et al 2012). 
Although the decreased survival rate in $M$. incanus population can be a consequence of higher dispersal (instead of higher mortality), the clear temporal change in population age structure and abundance does not suggest this is the case. By the end of the year, when only adults are captured, abundance decreases which reinforces an increased mortality. Elsewhere the occurrence of fur loss in the rump and parasite infestation in a few males after the mating season for M. paulensis (Leiner et al 2008) and fur loss and declined body condition for G. microtarsus (Martins et al 2006) also indicate a high mortality for these species.

A partial semelparity, with only males presenting a high mortality after breeding, is common among Australian marsupials (Oackwood et al 2001, Fisher and Blomberg 2011). The analysis of survival rates of the Neotropical G. microtarsus also showed a partial semelparity, with decreased survival rates in the post-mating season in males but not females (Martins et al 2006). In contrast, we found that although males had lower survival rates than females in both periods, both sexes presented a lower survival during the mating period, indicating a full semelparous pattern in $M$. incanus. Indeed in the congeneric $M$. paulensis an annual replacement of generations was observed in both males and females (Leiner et al 2008).

The evolutionary causes and the physiological mechanisms of partial semelparity in Australian marsupials are the center of much debate (Oakwood et al 2001, Fisher and Bloomberg 2011). There is some evidence that females of partial semelparous populations tend to have higher mortality rates in comparison to iteroparous populations (Kraaijeveld et al 2003). For Neotropical species, the causes and mechanisms of semelparity or partial semelparity are not known, and should be the focus of future studies, since the accumulating evidence suggests these patterns are common, especially among small-sized species. Moreover, semelparity seems to be favored when costs of reproduction are high or when favorable environmental conditions are uncertain or ephemeral (Boonstra 2005, Merritt 2010). As the Atlantic Forest is a low-latitude biome, with a relative smooth variation in food availability, the apparent widespread semelparous pattern in 
small-sized Atlantic forest marsupials can be a consequence of phylogenetic constrains, instead of ecological or environmental drivers (Boonstra 2005).

Conclusion: Our results indicate that reproduction in small-sized, Atlantic Forest marsupials is seasonal, with juveniles being born and lactation occurring in the period of highest food availability, the warm-wet season. Reproduction onset is synchronous among species and is driven by photoperiod cues. Semelparity is probably the cause of a high population turnover in $M$. incanus, and also in co-occurring small-sized marsupials. Future studies should focus on the evolutionary causes and physiological mechanisms of reproductive seasonality and semelparity, taking into account the phylogenetic constrains. 

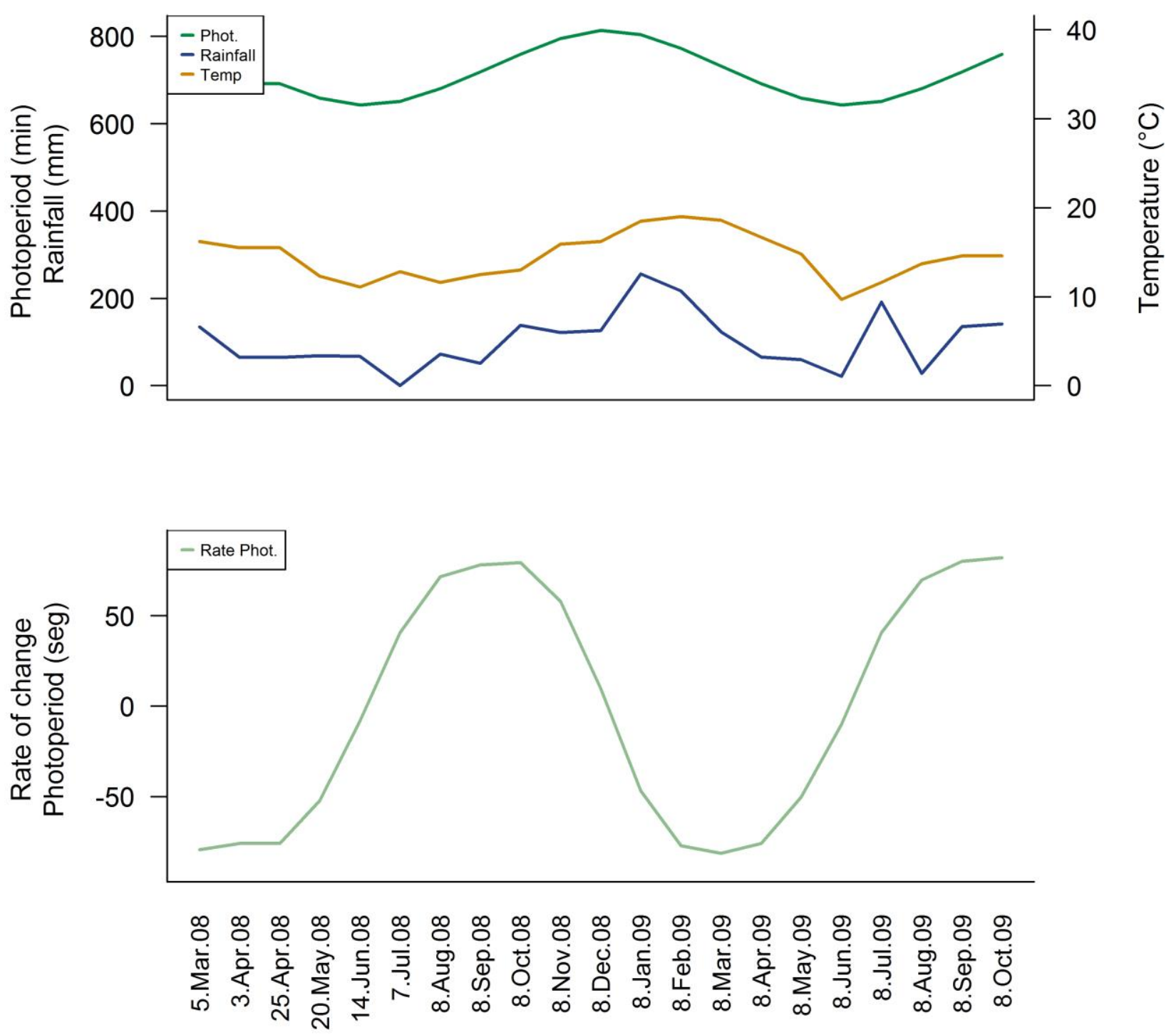

Figure S2.1: Temporal variation of mean monthly photoperiod, monthly rainfall, mean monthly minimum temperature and mean rate of change of photoperiod at the Morro Grande Forest Reserve. 


\section{Capítulo 3}

\section{Determinants of capture-recapture success to estimate population and assemblage parameters for small mammals}
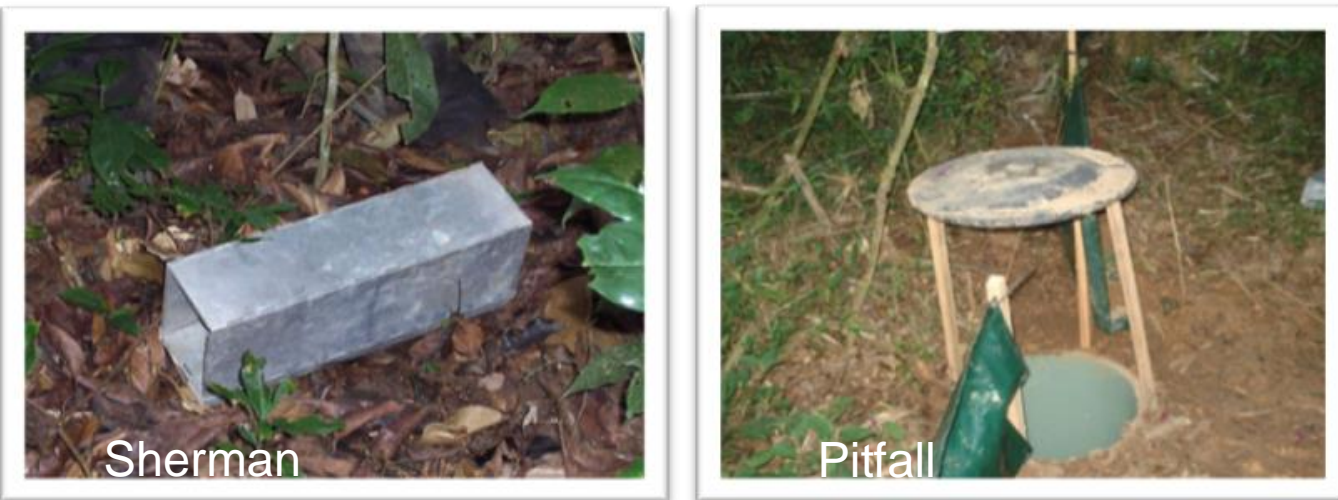


\title{
Capítulo 3
}

\section{Determinants of capture-recapture success to estimate population and assemblage parameters for small mammals}

\author{
Camila dos Santos de Barros ${ }^{1}$, Thomas Püttker ${ }^{2}$, Bruno Trevizan Pinotti ${ }^{2}$, Renata Pardini ${ }^{2}$ \\ ${ }^{1}$ Departamento de Ecologia $e^{2}$ Departamento de Zoologia, Instituto de Biociências, Universidade \\ de São Paulo, Rua do Matão - travessa 14, 101, CEP 05508-090, São Paulo, SP, Brasil (C.S.B.)
}

\section{Abstract}

Obtaining high-quality data on populations and assemblages in an efficient manner is paramount for a variety of ecological studies. In many instances these data come from live-trapping animals, the success of which depends on the trapping method and on morphological, ecological or behavioral characteristics of species and individuals. Additionally, both trapping efficiency and animal behavior may depend on weather conditions. However, few studies have evaluated concomitantly the influence of these different factors on the efficiency of sampling protocols. Here, we evaluate if small mammal capture success varies between 2 types of trap (Sherman and Pitfall), between animals of different ages and sexes, and with varying weather condition (rainfall and temperature). The efficiency of different trap methods was contingent on the quantified variables (number of species, of individuals or of recaptures), depended on the age and sex of the individuals, and was influenced by weather condition. Pitfall traps were less selective and captured more species and individuals, while Sherman traps more efficiently recaptured individuals, probably because capture in this type of trap is less traumatic. Both traps captured more males than females and more adults than juveniles. However, Pitfall traps tended to capture 
proportionally more juveniles than Sherman traps. The positive effect of rainfall on the number of captures was stronger in Pitfall traps, while with the effect of temperature was positive in Pitfall traps and negative in Sherman traps. Our results suggest that sampling protocols designed to estimate parameters associated with assemblages, such as species richness and composition, should be based on Pitfall traps. On the other hand, sampling protocols designed to estimate population parameters require the inclusion of both traps, to ensure the capture of individuals of different age classes (provided by Pitfall traps) as well as sufficient recaptures (provided by Sherman traps).

Key-words: abundance, Atlantic Forest, biodiversity survey, demography, field methods, marsupials, richness, rodents, trapping protocol

\section{Introduction}

Obtaining high-quality data on populations and assemblages in an efficient manner is paramount for a variety of ecological studies. Both studies focusing on hypothesis testing in population and community ecology and those aiming at monitoring populations and communities for practical purposes depends on efficient sampling protocols (Williams et al 2002, Magurran \& McGill 2011). Sampling efficiency is particularly important to allow the inclusion of a larger number of sites or species as well as the consideration of large spatial scales, both growing in importance in ecology and conservation (Dray et al 2012). The study of populations and assemblages of a large number of animal species, especially those with a cryptic life-style, depends on capture-recapture data from traps. The trapping success of animals depends on the interaction between the type of trap (i.e. its capture mechanism), the morphological characteristics of the species in focus, the ecology and behavior of individuals and species, and weather conditions, which can affect both the efficiency of traps and animal behavior. Thus, the choice of the type of trap is crucial for the 
quality of the data and therefore should be carefully considered when planning field sampling protocols.

Small mammals are cryptic and usually studied from captures in two types of traps: active traps, used in association with baits, the success of which depends on the exploratory behavior of individuals, and passive traps, where capture is the result of guiding the movements of individuals into pitfalls (Flowerdew et al 2004, Nicolas \& Colyn 2006). Due to these different capture mechanisms, trapping efficiency is expected to vary between these type of traps (Nicolas \& Colyn 2006, Dizney et al 2008, Torre et al 2010). Particularly, sex and age of individuals can interact with trap mechanisms to determine capture success. For example, males move longer distances than females in several small mammal species (Pires \& Fernandez 1999, Püttker et al. 2006) and may encounter drift-fences of passive traps more often, while juveniles may have less exploratory ability to find, or be too light, to trigger active traps (Nicolas \&Colyn 2006, Dizney et al 2008, Caceres et al 2011). However, the efficiency of different traps and sampling protocols depends also on the aim of the study. This is because different studies require different types of data. Particularly, community studies require as many individuals from as many species as possible (Magurran \& McGill 2011), while population studies require a representative subset of a population (i.e. different age classes and sexes) as well as achieving as many recaptures as possible (Williams et al 2002).

Pitfall traps, which can capture more than 1 individual per night, should capture more individuals, and therefore a larger number of species. As passive traps, captures should also be less dependent on the exploratory behavior of individuals/ species and thus result in a better representation of ages and sex. Hence, Pitfall traps are expected to be important for community studies (to estimate species richness and composition) as well as for population studies to allow captures of different age classes and sex (Williams et al 2002). Although previous studies have shown that Pitfall traps capture more juveniles (Nicolas \& Colyn 2006, Dizney et al. 2008, Cáceres 
et al 2011), no study has evaluated differences in capture success between sexes. However, results on the number of individuals and species are incongruent, with some studies indicating more individuals and species in Pitfall traps (Umetsu et al 2006, Caceres et al 2011), and others in Sherman traps (Nicolas \& Colyn 2006, Santos-Filho et al 2006).

On the other hand, baited box-traps such as Sherman traps provide food and shelter, thereby reducing stress and trauma of captured animals (White et al. 1982), which may favor recapture. If so, Sherman traps would be essential in population studies. However, despite the fact that several studies assessed the number of captures in different traps (i.e. Nicolas \& Colyn 2006, Santos-Filho et al 2006, Umetsu et al 2006, Dizney et al 2008, Caceres et al 2011), none considered the number of recaptures. This is probably because many of the available studies are short-term, based on lines of traps with few traps covering a small area, and are thus limited for evaluating recaptures (e.g. Nicolas \& Colyn 2006, Umetsu et al 2006, Caceres et al 2011).

Weather conditions, particularly rainfall and temperature, can affect capture probability by affecting either the activity of animals (thus the chance of encountering a trap) or the effectiveness of the trap-mechanism. In small mammals, the high surface-volume ratio favors the loss of heat and water through respiration (Vickery \& Bider 1981, Halle 2000), making them less active in colder or dryer weather conditions. Accordingly, some studies found a positive relationship between temperature and activity of small mammals (Vickery \& Bider 1981, Vieira et al 2010) with some species entering torpor at extreme low temperatures in combination with low rainfall (Bozinovic et al. 2005). On the other hand, small mammals have been shown to enter in torpor also at extremely high temperatures (Geiser \& Baudinette 1987, Bozinovic et al 2004). Likewise weather conditions may interfere with the efficiency of both active and passive traps: in forest environment active traps may be closed due to stormy conditions, or prevent the escape of trapped animals in passive traps given the accumulation of water in the buckets (Voss et al 2001). Further, drift-fences of passive traps may be more effective when weather conditions favor 
animal activity (e.g. depending on temperature). However, few studies evaluated the influence of weather conditions on small mammal captures.

Here we investigate simultaneously the effects of individual traits (sex and age), as well as weather conditions (rainfall and minimum temperature) on capture and recapture efficiency in Sherman and Pitfall traps, the two most commonly used traps for small mammals. We draw on a large capture-recapture dataset on small mammals from three 2-ha grids trapped for almost two years. Analyzing the number of captured species, individuals and recaptures, we aim to provide guidance on how to design efficient sampling protocols for small mammal studies focusing on estimating either assemblage or population parameters. Specifically we investigated: (1) if the

number of species, individuals and recaptures vary between types of trap, and (2) if individual traits (age and sex) and (3) weather conditions (minimum temperature and rainfall) influence the number of captures and interact with types of trap.

\section{Materials and methods}

Study area and data collection

The study was carried out at the Morro Grande Forest Reserve (2339'-234ㅇ' Cotia, São Paulo, Fig. 1), a 9400-ha reserve connected to other large tracts of forest, being part of the largest remnant of Atlantic Forest in Brazil. The reserve is covered by Lower Montane Atlantic Rain Forest in different regeneration stages (Metzger et al 2006). The altitude varies from 850 to $1100 \mathrm{~m}$ above sea level. Mean maximum temperature is $27^{\circ} \mathrm{C}$ and mean minimum temperature is $11^{\circ} \mathrm{C}$. Mean annual rainfall is $1339 \mathrm{~mm}$, with the wet and warm season from September to March (Metzger et al 2006). The non-flying small mammal fauna is very diverse, including rare and endemic Atlantic Forest species (Pardini \& Umetsu 2006).

We placed three 2 ha trap grids (100 m x $200 \mathrm{~m}$ ) at least two km apart at the Reserve (Fig.3. 1). Each grid was comprised of 11 100-m long lines, 20m apart from each other, each composed of 11 
trap stations every $10 \mathrm{~m}$. Six alternated lines had only 11 Sherman traps $(37.5 \times 10.0 \times 12.0 \mathrm{~cm}$ or $23.0 \times 7.5 \times 8.5 \mathrm{~cm})$ on the ground. The other five lines had, in addition to the Sherman traps, 11 Pitfall traps (60 L buckets buried at the ground, connected by $50-\mathrm{cm}$ high drift-fences) at the same trap stations, totaling 121 Sherman traps and 55 Pitfall traps per grid (Fig. 3.1). The efficiency of Pitfall traps depend on the size of buckets (Ribeiro-Junior et al 2011), and it thus is important to notice that we used large (60 L) Pitfall traps. In order to reduce mortality we (1) drilled small holes at the bottom of the buckets to prevent water accumulation, (2) placed Styrofoam at the bottom to provide dry surface for fluctuation in case of water accumulation, (3) placed food in the buckets for feeding, and (4) installed bucket lids at $50 \mathrm{~cm}$ height, functioning as an umbrella. All traps received daily baits consisting of mashed bananas, cornmeal, peanut butter and sardines.

We performed 21 five-night capture sessions between March 2008 and October 2009. Intervals between sessions varied from 16 to 30 days (mean of 23.4 days). Captured individuals were marked with aluminum tags with unique codes, allowing individual identification. Voucher specimens of all species were collected in a pilot sample, identified by experts, and are kept in the Department of Zoology, University of Sao Paulo. For each capture we recorded the species, sex, reproductive condition, and body weight and, for marsupials, the tooth eruption pattern. Reproductive activity in females was determined by pregnancy or the presence of swollen teats, while in males it was determined by testicles in the scrotal position (for rodents only). Age classes for rodents were estimated by body mass, assuming the minimum weight of a reproductive individual (separately for each sex) as the threshold between juveniles and adults. For marsupials, age classes were determined by tooth eruption patterns ( Tribe 1990, Macedo et al 2006).

During all sessions, daily rainfall (averaged between two pluviometers placed close to the grids on the Reserve's main road) and daily minimum temperature (from hourly records obtained with data loggers placed in each grid) were recorded. We chose to use minimum (rather than mean or maximum) temperature as we expect this variable to have a stronger effect on small mammals. 


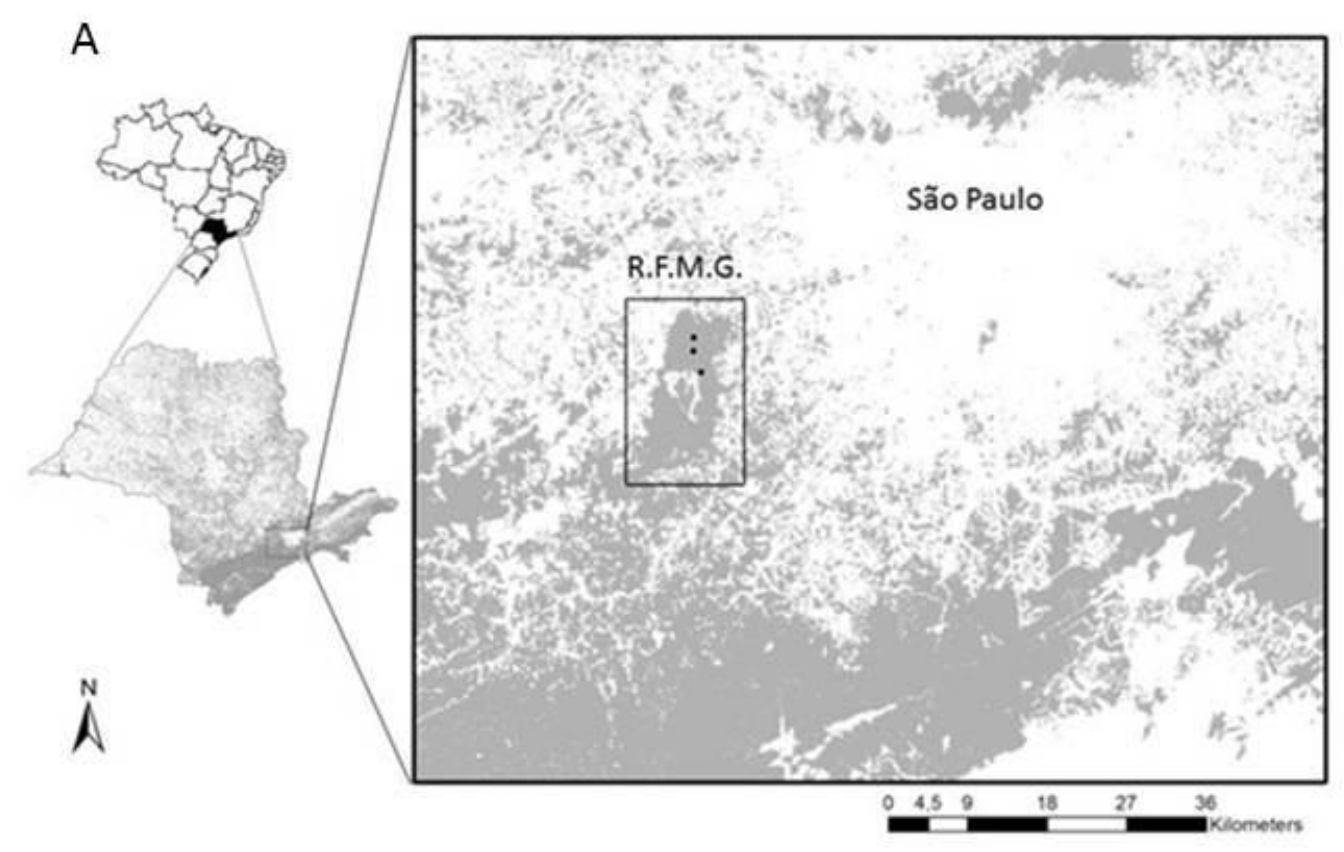

B

a

Figure 3.1: A. Location of the 3 trapping grids (dots) at the Morro Grande Forest Reserve (R.F.M.G.), State of São Paulo, Brazil. Gray: forests. B. Trapping grids used to capture small mammals. Rectangles: Sherman traps; circles: Pitfall traps connected by drift fences (lines). 


\section{Data analysis}

Initially, to evaluate how the number of species accumulate as a function of sampling effort we used mean accumulation curves of the number of species per capture session and per individual for each type of trap, using package vegan for program R (Oksanen et al 2012).

We considered three different candidate model sets for answering our three main questions (see below), and used the Akaike information criterion (AIC) for model selection in each case. AIC values of each model were subtracted from the AIC value of the best model $(\Delta \mathrm{i})$, and models with $\Delta \mathrm{i} \leq 2$ were considered equally plausible(Burnham \& Anderson 2002). All analyses were run in program R, version 2.13.0 ( $R$ 2011) using Imer4 package (Bates et al 2011), and scripts are found in Appendix 1.

We used Generalized Linear Mixed-Effects models (GLMM) in all cases, allowing the incorporation of time and space dependency through the use of random intercept and slope factors (Bolker et al 2009; Appendix 1). For all models, grids and capture sessions were considered random intercept factors and species was considered random intercept and slope factor (except in the model for richness, since in this case there is no data for different species). Dependent variables were computed considering the data from the 6 species with enough captures for a robust analysis (species with more than 120 captures; Table S3.1), except for richness, which was computed considering the whole data set. All dependent variables were modeled using Poisson error distribution.

Effects of the type of trap on the number of species, individuals and recaptures: The dependent variables number of species (richness), number of individuals, and number of recaptures (total captures except the first capture) were computed for each type of trap for each capture session in each grid. Candidate models for each of the three dependent variables included two models: a 
constant model (no fixed factor) and a model considering trap type as fixed factor (Table 3.1). Recapture models also included the individuals as an extra intercept random factor.

Since the sampled area differs between the two types of trap, dependent variables for Sherman traps were computed using two data-subsets: (A) considering only the five lines containing both types of trap, or (B) considering only the five lines containing exclusively Sherman traps (excluding the sixth of these lines). Thus models for each dependent variable were run twice (once for each data-subset), allowing us to evaluate the influence of the proximity of Pitfall lines on the efficiency of Sherman traps.

Effects of individual traits and weather condition on the number of captures: Since our results indicated a negative effect of the presence of Pitfall traps on captures in adjacent Sherman traps (see results), the following analyses considered only the data-subset for Sherman traps from the five lines containing exclusively these traps. Two similar candidate model sets were constructed. To investigate the effects of individual traits (age and sex) and their interaction with the type of trap, the dependent variable was the total number of captures (i.e., sum of first capture and recaptures) in each grid and capture session. Fourteen candidate models were compared, considering a constant model (without fixed factors), three simple models (with each of the three fixed factors: type of trap, sex and age), all four possible additive combinations of fixed factors, and 6 interaction models (excluding only the interaction among the three fixed factors due to the difficulty of interpreting such complex interactions, Table 3.2). To investigate the effects of weather condition (temperature and rainfall) and their interaction with trap type, the dependent variable was again the number of total captures (sum of first capture and recaptures), but in this case for each grid and day of sampling (since weather conditions were measured daily). Candidate model set follows the same logic of the one for sex and age, but also included the day as an extra intercept random factor. 


\section{Results}

In total, we captured 1273 individuals from 24 species 3608 times. Of these, 1558 captures of 927 individuals of 23 species (14 rodents and 9 marsupials) were obtained in 17325 Pitfall-nights (9\% capture success), and 2050 captures of 346 individuals of 15 species ( 8 rodents and 7 marsupials) in 34650 Shermans-night (6\% capture success) (see also Table S3.1). Mortality rate in Pitfall traps was $3.97 \%$ and in Sherman traps $2.07 \%$ of the individuals captured. All species captured in Sherman traps, except for one, were also captured in Pitfall traps (Table S3.1). For any given sampling effort, Pitfall traps captured more species than Sherman traps, and the accumulated number of species leveled off sooner in Sherman than in Pitfall traps (Fig. 3.2).
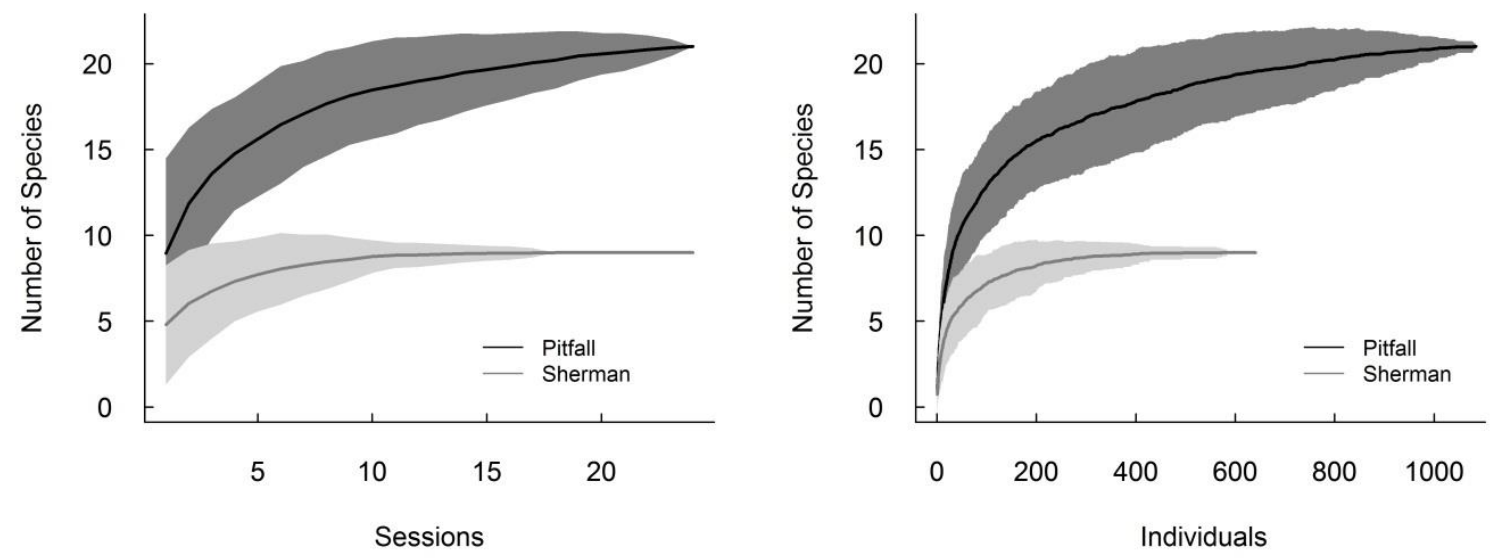

Figure 3.2: Mean accumulation curves of the number of species (mean and standard deviation) as a function of sampling effort (either the number of capture sessions or the number of captured individuals) for Pitfall and Sherman traps at the Morro Grande Forest Reserve.

Effects of the type of trap on the number of species, individuals and recaptures: Considering both data-subsets from Sherman traps, the model including the type of trap as a fixed factor was more plausible than the constant model for both the number of species and of individuals (Table 3.1), which were higher in Pitfalls than in Sherman traps (Fig. 3.3 and Fig. 3.4). However, the effect of the type of trap was stronger when considering data-subset A (captures in Sherman traps 
adjacent to Pitfall traps), especially for the number of species (Fig. 3.3, Table 3.1), indicating that Sherman traps captured less species when adjacent to Pitfalls.

On the other hand, for the number of recaptures, both models were equally plausible considering both data-subsets from Sherman traps (Fig. 3.4, Table 3.1). While B. soricinus and O. nigripes had more recaptures in Pitfall traps, all four remaining species had markedly more recaptures in Sherman traps, especially when considering results from Sherman traps not-adjacent to Pitfall lines (Fig. S3.1).

Table 3.1: Results of model selection for the number of species, of individuals and of recaptures of small mammals as a function of the type of trap. Two data-subsets were used for Sherman traps: only captures from Sherman placed adjacent to Pitfall traps (A) or from Sherman traps intercalated with Pitfall lines (B). Check the text for random factors. K: number of parameters; $\Delta_{i}$ : difference in AIC value compared to the best model; wi: Akaike weight. Selected models $\left(\Delta_{i}<2\right)$ are in bold.

\begin{tabular}{lllll}
\hline & Model & $K$ & $\Delta_{i}$ & $\omega_{i}$ \\
\hline NUMBER OF SPECIES & & & & \\
A & trap & 4 & 0.0 & 1.00 \\
& cte & 3 & 44.4 & 0.00 \\
B & trap & 4 & 0.00 & 0.98 \\
& cte & 3 & 8.24 & 0.02 \\
NUMBER OF INDIVIDUALS & & & & \\
A & trap & 7 & 0.0 & 0.90 \\
& cte & 6 & 4.4 & 0.10 \\
B & trap & 7 & 0.0 & 0.81 \\
& cte & 6 & 3.0 & 0.19 \\
NUMBER OF RECAPTURES & & & & \\
A & cte & $\mathbf{7}$ & $\mathbf{0 . 0}$ & $\mathbf{0 . 5 7}$ \\
& trap & $\mathbf{8}$ & $\mathbf{0 . 6}$ & $\mathbf{0 . 4 3}$ \\
B & cte & $\mathbf{7}$ & $\mathbf{0 . 0}$ & $\mathbf{0 . 7 3}$ \\
& trap & $\mathbf{8}$ & $\mathbf{2 . 0}$ & $\mathbf{0 . 2 7}$ \\
\hline
\end{tabular}




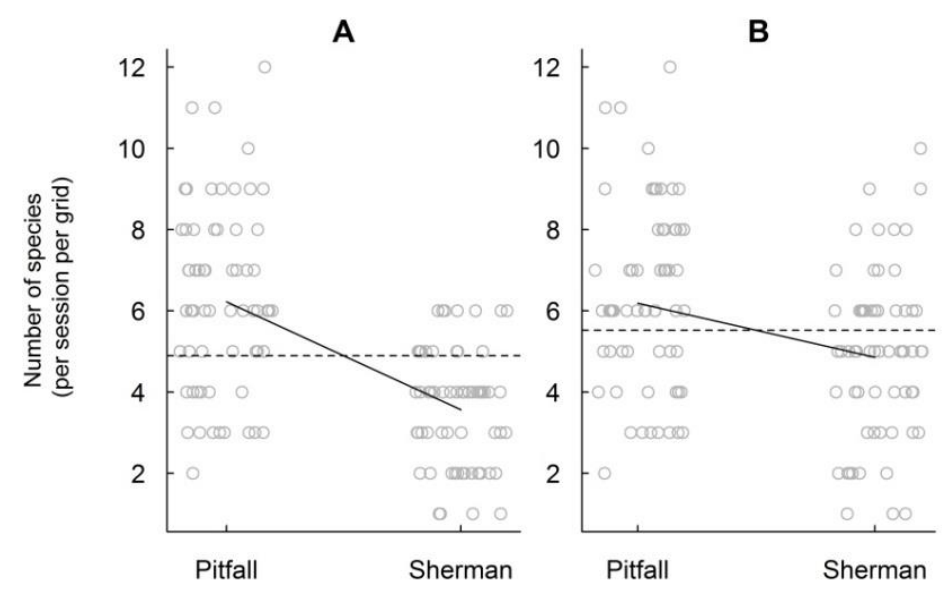

Figure 3.3: Number of small mammal species captured in Pitfall and Sherman traps. Overlapping dots are horizontally scattered to improve visualization. Two data-subsets were used for Sherman traps: only captures from Sherman placed adjacent to Pitfall traps $(A)$ or from Sherman traps intercalated with Pitfall lines (B). Expected means for each trap type estimated by constant models (dotted lines) and by models with trap type as a fixed factor (solid lines).

A
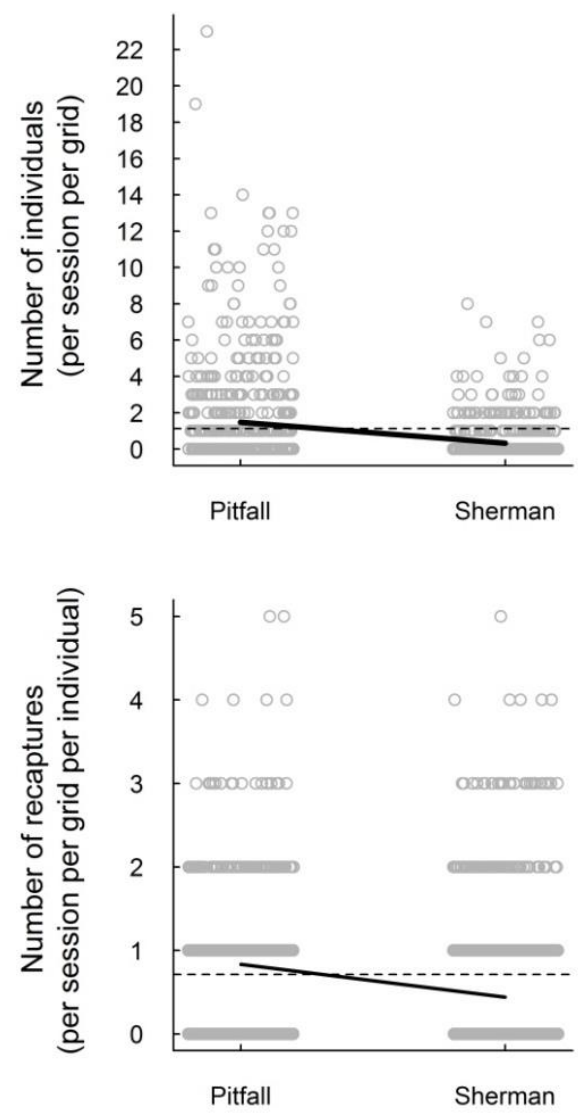

B
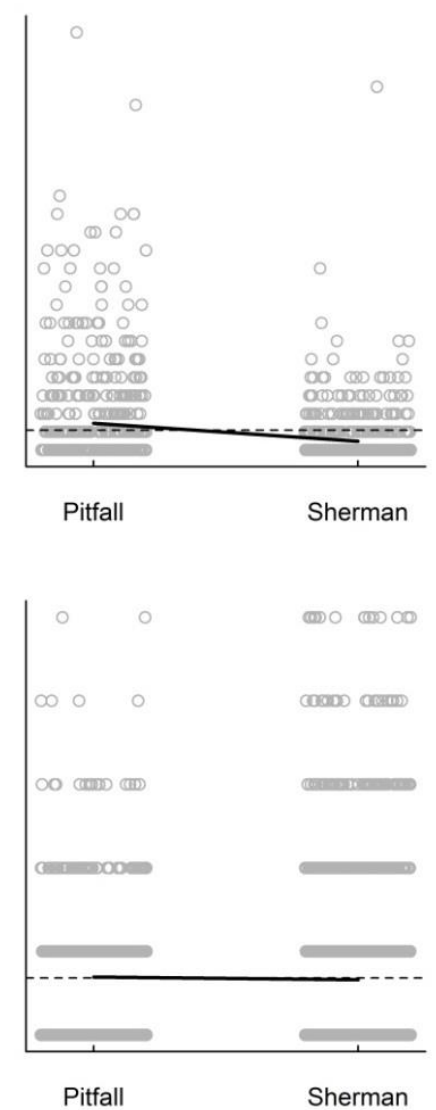

Figure 3.4: Number of individuals and recaptures in Pitfall and Sherman traps. Overlapping dots are horizontally scattered to improve visualization. Two data-subsets were used for Sherman traps: only captures from Sherman traps placed adjacent to Pitfall traps (column A) or from Sherman traps intercalated with Pitfall lines (column B). Expected means for each trap type estimated by constant models (dotted lines) and by models with trap type as a fixed factor (solid lines). 
Effects of individual traits (sex and age): The only selected model (with a delta AIC of $>20$ to the next-ranked model) was the most complete model, with the additive effect of the three fixed factors and the interaction of both sex and age with trap type, while the constant model was the last-ranked model (Table 3.2). All models that included age were better than those including sex but not age, indicating that capture is more influenced by age than sex (Table 3.2). Adults and males were captured more than juveniles and females in both traps (Fig. 3.5). However, the only selected model indicates that the effects of both age and sex depended on trap type (interactions) (Fig. 3.5). The coefficients of these interactions indicate that differences in the number of captures between adults and juveniles were stronger in Sherman traps, with proportionately more captures of juveniles in Pitfall traps, while the differences in the number of captures between males and females were stronger in Pitfall traps, with proportionately less captures of males in Sherman traps.

Effects of weather condition (minimum temperature and rainfall): Two models were equally plausible: the most complete model (additive effect of the three fixed factors and the interaction of both temperature and rainfall with the type of trap) and the one considering the additive effect of the three factors, but only the interaction between type of trap and temperature (Table 3.2). Again, selected models presented large differences in delta AIC to the next-ranked models and the constant model was among the worst models. The coefficients of the interaction terms of the best model indicates that temperature positively affected captures in Pitfall traps and negatively affected captures in Sherman traps, while rainfall positively affected captures in both traps, with a stronger effect in Pitfall than Sherman traps (Fig. 3.6). 
Table 3.2: Results of model selection for the number of captures of small mammals as a function of the type of trap, individual traits (age and sex), and weather condition (rainfall and minimum temperature), considering only captures from Sherman traps placed intercalated with Pitfall lines. Check the text for random factors. K: number of parameters; $\Delta_{\mathrm{i}}$ : difference in AIC value compared to the best model; $\omega$ i: Akaike weight. Selected models $\left(\Delta_{\mathrm{i}}<2\right)$ are in bold.

\begin{tabular}{|c|c|c|c|}
\hline Model & K & $\Delta_{\mathrm{i}}$ & $\omega_{\mathrm{i}}$ \\
\hline \multicolumn{4}{|l|}{ INDIVIDUAL TRAITS } \\
\hline trap+sex+age+trap:age+trap:sex & 29 & 0.0 & 1.00 \\
\hline trap+sex+age+trap:age & 22 & 20.7 & 0.00 \\
\hline trap+age+trap:age & 16 & 50.6 & 0.00 \\
\hline trap+sex+age+trap:sex & 22 & 264.1 & 0.00 \\
\hline trap+sex+age & 16 & 270.7 & 0.00 \\
\hline trap+age & 11 & 305.0 & 0.00 \\
\hline age+sex+age:sex & 16 & 657.3 & 0.00 \\
\hline sex+age & 11 & 742.2 & 0.00 \\
\hline age & 7 & 778.1 & 0.00 \\
\hline trap+sex+trap:sex & 16 & 1080.3 & 0.00 \\
\hline trap+sex & 11 & 1092.2 & 0.00 \\
\hline trap & 7 & 1125.4 & 0.00 \\
\hline sex & 7 & 1565.2 & 0.00 \\
\hline constant & 4 & 1600.4 & 0.00 \\
\hline \multicolumn{4}{|l|}{ WEATHER CONDITION } \\
\hline trap+rainfall+temp+trap:rainfall+trap:temp & 30 & 0.0 & 0.68 \\
\hline trap+rainfall+temp+trap:temp & 23 & 1.5 & 0.32 \\
\hline trap+temp+trap:temp & 17 & 67.3 & 0.00 \\
\hline trap+rainfall+temp+trap:rainfall & 23 & 83.3 & 0.00 \\
\hline trap+rainfall+trap:rainfall & 17 & 116.7 & 0.00 \\
\hline trap+rainfall+temp & 17 & 123.4 & 0.00 \\
\hline trap+rainfall & 12 & 156.2 & 0.00 \\
\hline trap+temp & 12 & 192.0 & 0.00 \\
\hline trap & 8 & 254.0 & 0.00 \\
\hline rainfall+temp & 12 & 583.6 & 0.00 \\
\hline rainfall & 8 & 618.5 & 0.00 \\
\hline temp & 8 & 645.8 & 0.00 \\
\hline constant & 5 & 706.3 & 0.00 \\
\hline rainfall+temp+rainfall:temp & 17 & 160405.8 & 0.00 \\
\hline
\end{tabular}




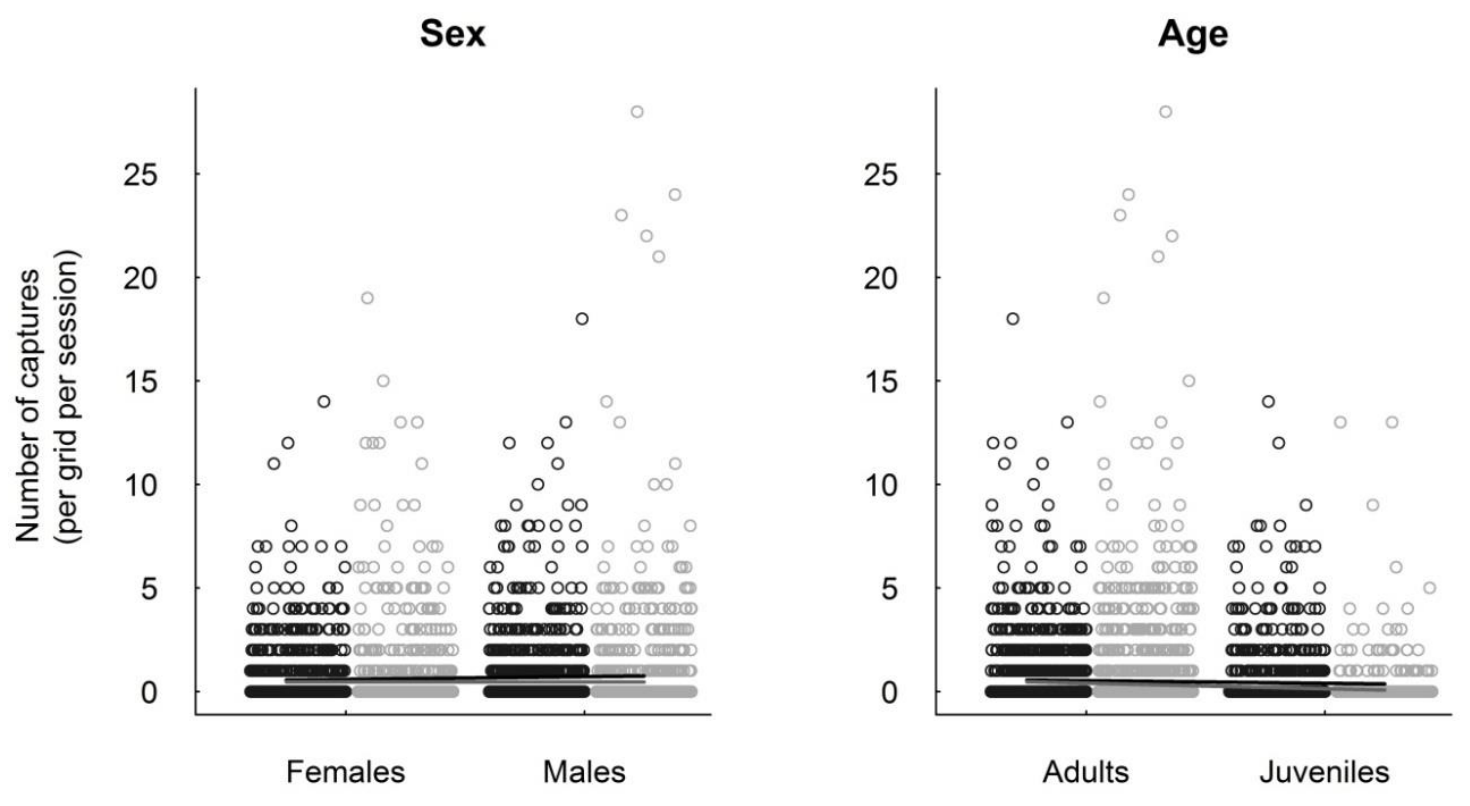

Figure 3.5: Graphical representation of the interactions between trap type (Pitfall traps: black dots; Sherman traps: gray dots) and sex or age in determining the number of captures. Overlapping dots are horizontally scattered to improve visualization. Expected means for each trap type and sex or age estimated by the best model in Table 2 (solid lines- Pitfall traps: black; Sherman traps: gray).
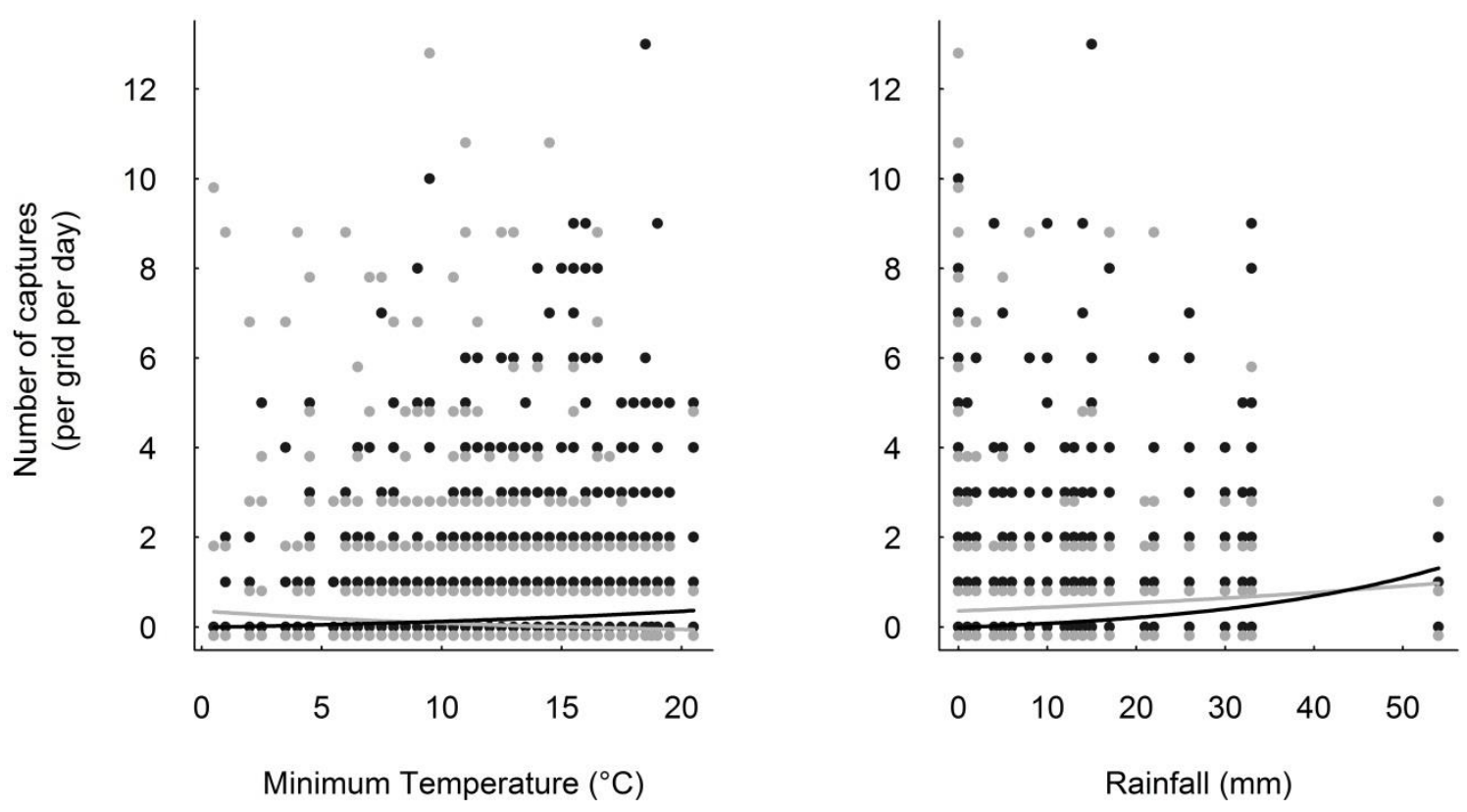

Figure3. 6: Graphical representation of the interactions between trap type (Pitfall traps: black dots; Sherman traps: gray dots) and rainfall or minimum temperature in determining the number of captures. Overlapping dots are horizontally scattered to improve visualization. Expected means for each trap type and rainfall or minimum temperature estimated by the best model in Table 2 (solid lines - Pitfall traps: black; Sherman traps: gray). 


\section{Discussion}

Effects of the type of trap on the number of species, individuals and recaptures: Our results suggest that Pitfall traps are more efficient than Sherman traps when considering both the number of species and the total number of individuals, as well as the number of four of the six species analyzed in detail. The higher richness and number of individuals in these passive traps are likely a result of the mechanism of interception that makes them less selective than Sherman traps. In contrast to Pitfall traps, the functioning of Sherman traps depends on the successful attraction of animals and thus on the exploratory behavior of individuals. Moreover, Pitfall traps allow the capture of more than one individual simultaneously, and thereby potentially more than one species, which happened frequently in this study.

It is noteworthy that Pitfall traps, even when using half of the number of buckets compared to the number of Sherman traps as in this study, captured in total $53 \%$ more species. Moreover, the accumulated number of species was higher than for Sherman traps in any given sampling effort. Previous studies that also used large buckets $(\geq 60 \mathrm{l})$ also obtained more species in Pitfall traps (Umetsu et al 2006, Caceres et al 2011), while studies that used smaller buckets all captured more species in Sherman traps ( Nicolas \& Colyn 2006, Santos-Filho et al 2006, Dizney et al 2008). However, we found only one study that had replicates and statistically compared mean number of species and of individuals between types of traps. As observed in this study, mean number of species and of individuals was also higher in Pitfall traps (Umetsu et al 2006).

Because all seven species with less than five captures were exclusively captured in Pitfall traps, our results also highlight the higher chance of detecting rare species with these passive traps, including new species such as the recently described arboreal rodent Drymoreomys albimaculatus (Pecequillo et al 2011). Moreover, there was only one species exclusively captured in Sherman traps, the semi-aquatic rodent Nectomys squamipes. However, considering all inventories carried out at the Reserve, no small mammal species was captured exclusively in Sherman traps, even 
though previous studies included Sherman traps placed in the understory (Pardini \& Umetsu 2006, Pinotti 2010). This result reveals that Sherman traps are not complementary to Pitfall traps in terms of assessing assemblage richness and composition, as has been previously suggested (Lyra-Jorge \& Pivello 2001). In contrast, our study clearly indicates the critical importance of large Pitfall traps for biodiversity surveys and monitoring as well as for studies in community ecology, which aim at estimating richness and composition of small mammal assemblages.

On the other hand, although model selection indicated that the type of trap does not influence the total number of recaptures, most species had more recaptures in Sherman traps. Only the two smallest species had more recaptures in Pitfall traps (weight: B. soricinus mean $=29.3 \mathrm{~g}$, maximum $=37.0 \mathrm{~g} ;$ and $O$. nigripes mean $=18.4 \mathrm{~g}$, maximum $=30.0 \mathrm{~g})$, probably because the efficiency of the trigger mechanism of Sherman traps depends on body mass (Astua et al 2006, Nicolas \& Colyn 2006, Dizney et al 2008, Caceres et al 2011). Higher number of recaptures in Sherman traps may indicate that animals learn in the first capture to avoid or seek certain types of traps after the first experience. Sherman traps provide protection and probably reduce stress and trauma (White et al 1982), while individuals in Pitfall traps are exposed to other animals and to weather condition. Our results suggest the major importance of using Sherman traps for both basic and applied population studies, which require a large number of individual recaptures to obtain accurate and precise estimates of demographic parameters, such as abundance, and rates of survival, recruitment and population growth (Williams et al 2002).

Finally, differences in the number of recaptures and of species between the two types of trap, when placed in the same or in alternate lines, suggest that Pitfall lines reduce the efficiency in Sherman traps nearby, which should be considered when planning sampling protocols. Individuals that are likely to be captured in Sherman traps were probably stopped by Pitfall drift-fences.

Effect of individual traits (sex and age): Besides affecting the number of species, individuals and recaptures, the type of trap interacts with individual traits to determine capture success. 
Although both types of trap captured more males than females and more adults than juveniles, the strength of these biases depended on the type of trap. While Sherman traps captured proportionally less males in relation to females, Pitfall traps captured proportionally more juveniles in relation to adults.

Since an unbalanced sex ratio in the populations of all 6 species is unlikely (Hardy 2002), the bias towards males is likely the result of behavioral differences in the use of space between sexes. In several small mammals species, males have larger home ranges and travel longer distances than females (Pires \& Fernandez 1999, Püttker et al 2006, Gomez et al 2011), which should increase the probability of encountering a trap. The length of drift-fences, which acts passively and independently of exploratory behavior or baits, may account for the proportionately higher number of males captured in Pitfall traps compared to Sherman traps. On the other hand, adults tend to be more abundant than juveniles in small mammal populations (e.g. Gentile et al 2000, Feliciano et al 2002, Barros et al 2008) and a higher number of captured adults is expected. However, Sherman traps captured proportionally fewer juveniles than Pitfall traps, probably as a consequence of differences in exploratory behavior or body size between age classes. Adults exhibit well-developed exploratory behavior and are heavier, characteristics that are important for captures in Sherman traps, either for finding the bait or to trigger the door-closing mechanism of Sherman traps (Nicolas \& Colyn 2006, Dizney et al 2008, Caceres et al 2011).

This result highlights the importance of including Pitfall together with Sherman traps in population studies. A higher efficiency in capturing juveniles is particularly important for studies focusing on studying reproduction or on estimating emigration, immigration and dispersal rates (Williams et al 2002).

Effect of weather condition (minimum temperature and rainfall): Our results show that the type of trap interacts also with weather condition to determine capture success. Captures in Pitfall traps increased, while captures in Sherman traps decreased, with increasing minimum daily 
temperature. Again this result is congruent with the differences in capture mechanism between passive and active traps. Due to the high surface/volume ratio, small mammals tend to lose heat and water easily (Vickery \& Bider 1981, Merritt 2010), and high temperature favors the activity of these animals (Vickery \& Bider 1981, Paise \& Vieira 2006, Merritt 2010, Vieira et al 2010). However, decrease in activity with decreasing minimum daily temperature is expected to affect more strongly capture probability in passive Pitfall traps that depend on animals encountering drift-fences, than in active Sherman traps, which also provide shelter that may be more attractive under low temperature.

On the contrary, increasing rainfall positively affected captures in both traps, but the effect was stronger in Pitfall traps. This result is congruent with the idea that both the activity (which should affect strongly Pitfall traps) and the search for shelter (which should affect Sherman traps) should increase with increasing rainfall. The stronger effect of rainfall on captures in Pitfall traps may be related to the fact that the accumulation of water in the buckets prevent the escape of trapped animals (Voss et al 2001, Santos-Filho et al 2006, Nicolas \& Colyn 2006). Alternatively, rain could affect the way animals move, by keeping them close to objects for shelter, thus increasing the efficiency of Pitfall drift-fences. These results suggest that Pitfall traps should be more efficient in warm, rainy days, while Sherman traps should be more effective during cold, rainy days.

In conclusion, our large spatial and temporal sampling effort allowed a high number of captures of several species and thus the simultaneous evaluation of the effects of distinct factors on capture success of small mammal species. Our results reinforce the differences in efficiency between the most commonly-used types of traps, but more importantly they highlight that trap efficiency is highly dependent not only on the quantity considered (species, individuals or recaptures) but also on animal traits and weather condition. The observed differences between traps and interactions with age, sex, temperature and rainfall suggest that large Pitfall traps should be used whenever the focus is on biodiversity and other assemblage parameters, and are particularly crucial in 
species-rich tropical assemblages with a high proportion of rare species. These passive traps should be used in the warm-wet season, when their efficiency should be higher. On the other hand, population studies focusing on demographic parameters require the combined use of Pitfall and Sherman traps. While Pitfall traps ensure a larger number of individuals and a higher proportion of juveniles, Sherman traps assure higher recapture rates for most species. However, Sherman and Pitfall traps should be placed far apart, since Pitfall lines seem to reduce captures in Sherman traps nearby. Finally, our study calls for caution in comparing results obtained with different traps or different seasons, given the considerable differences between Sherman and Pitfall traps in the number of individuals, and particularly in the number of species, captured. The results also highlight the value of standardized surveys for both basic and applied studies in ecology and conservation. 
A

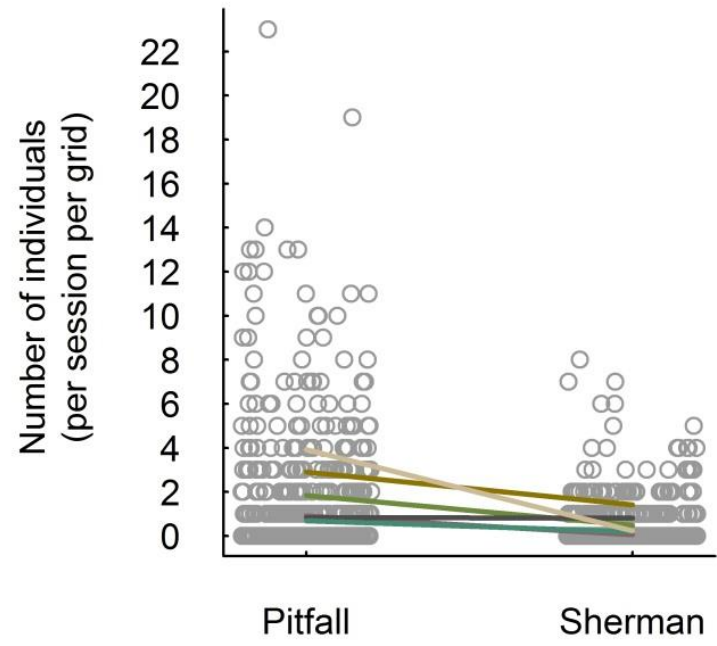

A

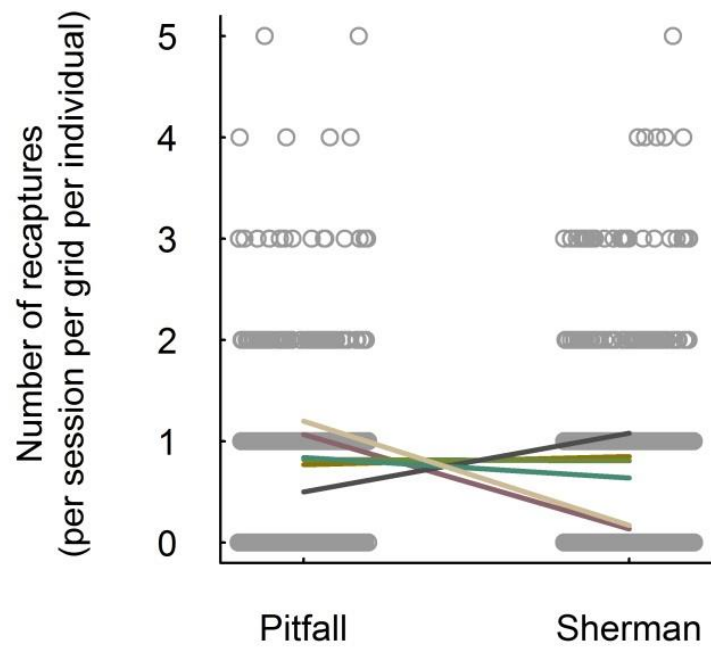

B

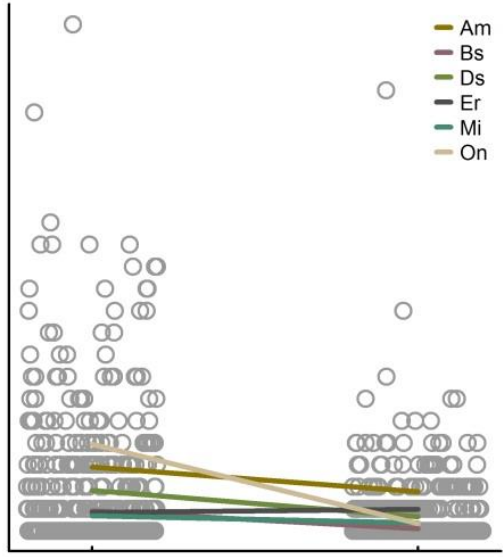

Pitfall

Sherman

B

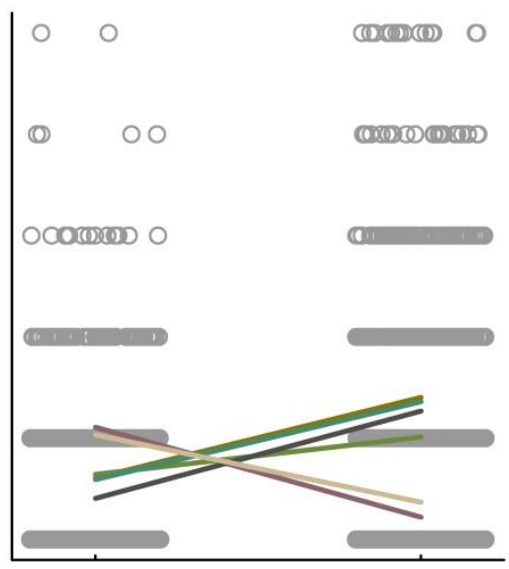

Pitfall

Sherman

Figure S3.1: Number of individuals and number of recaptures in Pitfall and Sherman traps. Overlapping dots are horizontally scattered to improve visualization. Two data-subsets were used for Sherman traps: only captures from Sherman traps placed adjacent to Pitfall traps (column A) or from Sherman traps intercalated with Pitfall lines (column B). Colored lines: random effects of species (Am: A. montensis, Bs: B. soricinus, Ds: D. sublineatus, Er: E. russatus, Mi: $M$. incanus, On: O. nigripes). 
Table S3.1: Number of captures and number of individuals (in parentheses) obtained in each type of trap and in total for each small mammal species from the Morro Grande Forest Reserve. Numbers for Pitfall traps are from the set of 5 trap lines per grid, and for Sherman traps are from the set of 5 trap lines per grid intercalated with Pitfall lines or from the set of 5 trap lines per grid adjacent to Pitfall traps. Due to the impossibility to separate the cryptic species Monodelphis americana and M. scalops in the field, individuals from both species were considered together.

\begin{tabular}{|c|c|c|c|c|}
\hline & Pitfall traps & $\begin{array}{c}\text { Intercaleted } \\
\text { Sherman traps }\end{array}$ & $\begin{array}{c}\text { Adjacent } \\
\text { Sherman traps }\end{array}$ & Total \\
\hline Akodon montensis & $389(166)$ & $580(72)$ & $269(23)$ & $1237(261)$ \\
\hline Delomys sublineatus & $235(128)$ & $195(30)$ & $114(13)$ & $544(171)$ \\
\hline Oligoryzomys nigripes & $405(293)$ & $43(7)$ & $22(7)$ & $470(307)$ \\
\hline Euryoryzomys russatus & $92(50)$ & $199(44)$ & $134(26)$ & $425(120)$ \\
\hline Thaptomys nigrita & $81(51)$ & $161(47)$ & $114(30)$ & $356(128)$ \\
\hline Marmosops incanus & $83(44)$ & 105 (19) & $31(4)$ & $219(67)$ \\
\hline Brucepattersonius soricinus & $109(68)$ & $7(1)$ & $3(0)$ & 119 (69) \\
\hline Didelphis aurita & $21(11)$ & $16(4)$ & $7(1)$ & $44(16)$ \\
\hline Monodelphis americana, M. scalops & $34(27)$ & $5(2)$ & $0(0)$ & $39(29)$ \\
\hline Monodelphis iheringi & $32(23)$ & $5(3)$ & $2(1)$ & $39(27)$ \\
\hline Sooretamys angouya & $10(9)$ & $9(4)$ & $6(2)$ & $25(15)$ \\
\hline Gracilinanus microtarsus & $23(21)$ & $0(0)$ & $0(0)$ & $23(21)$ \\
\hline Micoureus paraguayanus & $2(2)$ & $7(1)$ & $4(1)$ & $13(4)$ \\
\hline Juliomys pictipes & $12(10)$ & $0(0)$ & $0(0)$ & $12(10)$ \\
\hline Marmosops paulensis & $4(3)$ & $7(2)$ & $1(0)$ & $12(5)$ \\
\hline Monodelphis macae & $11(9)$ & $0(0)$ & $1(1)$ & $12(10)$ \\
\hline Bibimys labiosus & $5(3)$ & $0(0)$ & $0(0)$ & $5(3)$ \\
\hline Juliomys ossitenuis & $3(3)$ & $0(0)$ & $0(0)$ & $3(3)$ \\
\hline Nectomys squamipes & $0(0)$ & $3(1)$ & $0(0)$ & $3(1)$ \\
\hline Blarinomys breviceps & $2(2)$ & $0(0)$ & $0(0)$ & $2(2)$ \\
\hline Drymoreomys albimaculatus & $2(2)$ & $0(0)$ & $0(0)$ & $2(2)$ \\
\hline Oxymycterus judex & $1(1)$ & $0(0)$ & $0(0)$ & $1(1)$ \\
\hline Phyllomys nigrispinus & $1(1)$ & $0(0)$ & $0(0)$ & $1(1)$ \\
\hline total & 1557 (927) & $1342(237)$ & 708 (109) & 3607 (1273) \\
\hline
\end{tabular}

* T. nigrita was not considered among the species with more than 120 captures for the analysis because of high frequency of tag loss. 


\section{Appendix 1}

Generalized Linear Mixed-Effects models (GLMM) were used for analyses, allowing the incorporation of time (session and day) and space (grid) dependency through the use of random effects factors. Species were considered a random factor since differences among species were not the main focus of our study. However, different species may present different within-group variances, and may be differently affected by the independent variables included in our models. Thus we computed dependent variables considering the data from 6 most commom species and we considered the categorical variable "species" as a random intercept and slope factor in all models, excepting those for richness (Zuur et al 2009).

\section{R Script:}

\# Richness

attach(richness)

ric.cte $=\operatorname{Imer}($ formula $=\mathrm{n}$. species $\sim 1+(1 \mid$ grid $)+(1 \mid$ session $)$, family=poisson $)$

ric.trap=Imer (formula $=$ n.species $\sim$ trap $+(1 \mid$ grid $)+(1 \mid$ session $)$, family=poisson $)$

\section{\# Number of individuals}

attach(indiv.)

Ind.cte $=$ Imer (formula=n.individuals $\sim 1+(1 \mid$ grid $)+(1 \mid$ session $)+(1+$ trap $\mid$ species $)$, family= poisson $)$ Ind.trap $=$ Imer (formula=n. ndividuals $\sim \operatorname{trap}+(1 \mid$ grid $)+(1 \mid$ session $)+(1+$ trap $\mid$ species $)$, family=poisson $)$

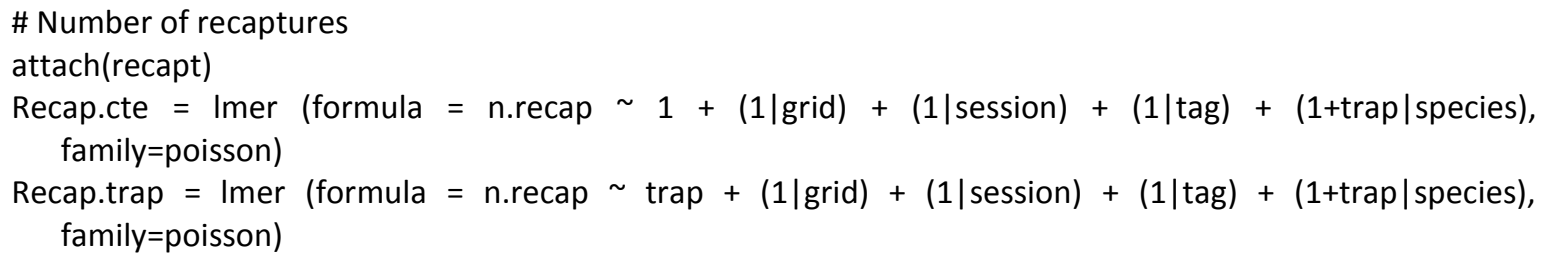


trap $=\operatorname{lmer}($ n.capt $\sim$ trap $+(1 \mid$ data $)+(1 \mid$ grid $)+(1 \mid$ session $)+(1+$ trap $\mid$ species $)$, family=poisson $)$

rain $=\operatorname{lmer}($ n.capt $\sim$ rain $+(1 \mid$ data $)+(1 \mid$ grid $)+(1 \mid$ session $)+(1+$ rain $\mid$ species $)$, family=poisson $)$

temp $=\operatorname{Imer}($ n.capt $\sim$ temp $+(1 \mid$ data $)+(1 \mid$ grid $)+(1 \mid$ session $)+(1+$ temp $\mid$ species $)$, family=poisson $)$

temp_plus_rain $=\operatorname{Imer}($ n.capt $\sim$ rain + temp $+(1 \mid$ data $)+(1 \mid$ grid $)+(1 \mid$ session $)+(1+$ rain + temp $\mid$ species $)$, family=poisson)

trap_plus_rain $=\operatorname{Imer}($ n.capt $\sim$ trap + rain $+(1 \mid$ data $)+(1 \mid$ grid $)+(1 \mid$ session $)+(1+$ trap + rain $\mid$ species $)$, family=poisson)

trap_plus_temp $=\operatorname{Imer}($ n.capt $\sim$ trap + temp $+(1 \mid$ data $)+(1 \mid$ grid $)+(1 \mid$ session $)+(1+$ trap + temp $\mid$ species $)$, family=poisson)

trap_plus_rain_plus_temp $=\operatorname{Imer}($ n.capt $\sim$ trap + rain + temp $+(1 \mid$ data $)+(1 \mid$ grid $)+(1 \mid$ session $)+(1+$ trap + rain + temp $\mid$ species), family=poisson)

trap_int_rain $=\operatorname{Imer}($ n.capt $\sim$ trap*rain $+(1 \mid$ data $)+(1 \mid$ grid $)+(1 \mid$ session $)+(1+$ trap + rain + trap:rain|species), family=poisson) trap_int_temp $=$ Imer (n.capt $\sim$ trap*temp $+(1 \mid$ data $)+(1 \mid$ grid $)+$ (1|session) + (1 + trap + temp + trap:temp $\mid$ species $)$, family=poisson)

rain_int_temp $=\operatorname{Imer}($ n.capt $\sim$ rain*temp $+(1 \mid$ data $)+(1 \mid$ grid $)+(1 \mid$ session $)+(1+$ rain + temp + rain:temp / species), family=poisson)

add_int_rain $=\operatorname{Imer}($ n.capt $\sim$ trap + rain + temp + trap:rain $+(1 \mid$ data $)+(1 \mid$ grid $)+(1 \mid$ session $)+(1+$ trap + rain + temp + trap:rain (species), family=poisson)

add_int_temp $=\operatorname{Imer}(\mathrm{n} . \mathrm{capt} \sim$ trap + rain + temp + trap $:+(1 \mid$ data $)+(1 \mid$ grid $)+(1 \mid$ session $)+(1+$ trap + rain + temp + trap:temp/species), family=poisson)

add_int_temp_rain $=\operatorname{Imer}($ n.capt $\sim$ trap + rain + temp + trap:rain + trap:temp $+(1 \mid$ data $)+(1 \mid$ grid $)+$

$(1 \mid$ session $)+(1+$ trap + rain + temp + trap:rain + trap:temp $\mid$ species $)$, family=poisson $)$

\#\#\#\#\# 


\section{CONSIDERAÇÕES FINAIS}

Esta tese contribuiu para a ampliação do conhecimento tanto sobre os fatores que influenciam a dinâmica populacional de roedores e marsupiais da Mata Atlântica, quanto sobre os fatores que determinam a obtenção de dados de qualidade para o estudo, seja das populações ou comunidades, destes animais.

Um dos resultados principais da tese são as evidências da ocorrência de uma demanda conflitante (trade-off) entre sobrevivência e reprodução em populações de roedores neotropicais, aspecto que não havia sido abordado em estudos anteriores. Em geral, os estudos de dinâmica populacional de roedores na região neotropical descreveram a importância da sobrevivência e/ou recrutamento (Talamoni e Dias 1999, Gentile et al 2000, Quental et al 2001, Feliciano et al 2002, Bonecker et al 2009), ou da reprodução (Bergallo 1994, D’Andrea et al 2007), para o tamanho dessas populações, a influência de variáveis ambientais sobre esses parâmetros populacionais (Bergallo \& Magnusson 1999, Lima et al 2001a,2001b, Graipel 2006, Lambert et al 2006, Antunes et al 2009, 2010) e o efeito denso-dependente (Lima et al 2001a,2001b, Previtalli et al 2006), mas nenhum trabalho focou especificamente na demanda conflitante entre reprodução e sobrevivência. Esse pode ser um padrão geral em espécies de roedores e merece maior atenção em estudos futuros devido a sua importância, em especial no que se refere às aplicações práticas no manejo e controle de pragas, já que o alto potencial reprodutivo de algumas dessas espécies de roedores as tornam propensas a atuarem como reservatórios de zoonoses (Bonecker et al 2009).

A reprodução é o período com maior demanda energética em mamíferos, o que torna importante a sincronização das etapas da reprodução com épocas mais favoráveis do ano em termos de disponibilidade de recursos (Speakman 2008). Contudo, a morfologia e fisiologia diferentes do sistema reprodutor dos marsupiais levam a estratégias reprodutivas distintas em relação aos mamíferos placentários (Tyndale-Biscoe 2005). Marsupiais australianos já têm seus padrões e 
estratégias reprodutivos amplamente descritos e bem compreendidos, enquanto pouco ainda se sabe sobre os mecanismos envolvidos na reprodução dos marsupiais neotropicais. Neste trabalho, foi possível contribuir com o avanço do conhecimento a respeito da reprodução dos marsupiais neotropicais, em especial em relação à época, à sincronia e aos gatilhos ambientais da atividade reprodutiva e ao padrão de semelparidade. Os resultados indicam que, especialmente para marsupiais de pequeno porte, a reprodução é sazonal e sincrônica, engatilhada por pistas ambientais associadas às mudanças de fotoperíodo e que a semelparidade pode ser difundida entre as espécies, mesmo em ambientes pouco sazonais como a Mata Atlântica.

Em especial, este trabalho contribuiu para a ampliação do conhecimento sobre espécies da Mata Atlântica cujos dados são escassos na literatura. Este foi o primeiro trabalho contendo informações sobre a reprodução de Delomys sublineatus, Monodelphis scalops e Monodelphis iheringi. O aumento do conhecimento sobre essas espécies é fundamental para o delineamento de estratégias de manejo e conservação. A espécie Monodelphis iheringi, por exemplo, é considerada uma espécie vulnerável à extinção no Estado de São Paulo (Carmignotto \& Pardini 2009) e uma espécie com dados deficientes na lista da IUCN (Brito et al 2008).

A obtenção de dados de espécies raras da Mata Atlântica neste estudo só foi possível devido ao desenho amostral utilizado, em especial devido à combinação de armadilhas de queda e armadilhas Sherman, e à grande área amostrada (6 ha no total). Apesar da diversidade brasileira ser considerada a maior do planeta, acredita-se que ainda haja uma grande quantidade de espécies não descritas, sendo marsupiais e roedores os principais grupos em que se espera encontrar muitas espécies novas no país (Paglia et al 2012). Os dados desta tese corroboram essa expectativa, uma vez que mesmo estando ao lado da maior cidade do país, capturamos na área de estudo uma nova espécie recentemente descrita pertencente a um gênero novo, o roedor Drymoreomys albimaculatus (Pecequillo et al 2011), e uma nova espécie do gênero Monodelphis que ainda está sendo descrita. 
No entanto, mesmo tendo sido baseado em um grande esforço amostral (55440 armadilhasnoite), muitas espécies não puderam ser avaliadas em detalhes; ao todo, 24 espécies foram capturadas, mas para apenas 10 foram obtidas capturas suficientes para as análises. Trabalhos de longa duração certamente auxiliam a observação de outros padrões temporais que não foram avaliados neste estudo, contudo dificilmente um esforço temporal maior levaria ao aumento significativo do número de capturas dessas espécies mais raras. Esse resultado leva a duas conclusões importantes: (1) Para boa parte das espécies de pequenos mamíferos neotropicias, a abundância é naturalmente muito baixa e mesmo esforços de campo muito grandes não possibilitam a utilização dos modelos estatísticos existentes; (2) estudos de populações e comunidades destes animais dependem de protocolos de captura bem planejados que aumentem a eficiência na obtenção dos dados necessários. Assim, o conhecimento sobre boa parte desta fauna diversa depende do desenvolvimento de novos modelos estatísticos que permitam o uso de dados mais escassos. Depende também do entendimento dos fatores que influenciam o sucesso de captura. Nesse sentido, esta tese contribuiu em identificar as vantagens e desvantagens dos dois principais tipos de armadilhas utilizadas no estudo de pequenos mamíferos, mostrando a importância das armadilhas de queda para estudos de comunidades, e do uso conjunto de armadilhas de queda e Shermans para estudos populacionais. 


\section{BIBLIOGRAFIA}

Antunes P.C., CAmpos M.A.A., Oliveira-SAntos L.G.R. \& GRAipel M.E. 2009. Population dynamics of Euryoryzomys russatus and Oligoryzomys nigripes (Rodentia, Cricetidae) in an Atlantic forest area, Santa Catarina Island, Southern Brazil. Biotemas 22:143-151.

Antunes P.C., CAmpos M.A.A., Oliveira-SAntos L.G.R. \& Graipel M.E. 2010. Population dynamics of Akodon montensis (Rodentia, Cricetidae) in the Atlantic forest of Southern Brazil. Mammalian Biology 75: 186-190.

ANUÁRIO DO OBSERVATÓRIO NACIONAL. 2008. http://www.on.br/conteudo/coaa/servicos/anuario_on/ dados_2008/downloads_2008_pag.html

ANUÁRIO DO OBSERVATÓRIO NACIONAL. 2009. http://www.on.br/conteudo/coaa/servicos/anuario_on/ dados_2009/downloads_2009_pag.html

ASTÚA D. \& GEISE L. 2006 Early reproductive onset in the white-eared opossum Didelphis albiventris Lund,1840 (Didelphimorphia, Didelphidae). Mammalian Biology 71:299-303.

Astua de Moraes D., Moura R.T., Grelle C.E.V. \& FonseCa M.T. 2006. Influence of baits, trap type and position for small mammal capture in a Brazilian lowland Atlantic Forest. Boletim do Museu de Biologia Mello Leitão (N. Sér.) 19: 31-44.

BAGUETTE M. \& SCHTICKZELLE N. 2003. Local population dynamics are important to the conservation of metapopulations in highly fragmented landscapes. Journal of Applied Ecology 40: 404-412.

Baladron A.V., MalizIA A.I., Bo M.S., Liebana M.S. \& BeCHARD M.J. 2012. Population dynamics of the southern short-tailed opossum (Monodelphis dimidiata) in the Pampas of Argentina. Australian Journal of Zoology 60: 238-245.

Baron J., Le Galliard J., Ferrière R. \& Tully T. 2013. Intermitttent breeding and the dynamics of resource allocation to reproduction, growth and survival. Functional Ecology 27: 173-183.

Barros C.S., Crouzellles R. \& Fernandez F.A.S. 2008. Reproduction of the opossums Micoureus paraguayanus and Philander frenata in a fragmented Atlantic Forest landscape in Brazil: is seasonal reproduction a general rule for Neotropical marsupials? Mammalian Biology 73: 463-467.

BAtes D., MAeChler M. \& BolkeR B. 2011. Lme4: Linear mixed-effects models using S4 classes. R package version 0.999375-42.http://CRAN.R-project.org/package=Ime4

BeRGaLLO H.G. 1994. Ecology of a small mammal community in an Atlantic rain forest area in southeastern Brazil. Studies on Neotropical Fauna and Environment 29: 197-217.

Bergallo H.G. \& MAGNUSSON W.E. 1999. Effects of climate and food availability on four rodent species in southeastern Brazil. Journal of Mammalogy 80: 472-486.

BERGALLO H.G. \& MAGNUSSON W.E. 2004. Factors affecting the use of space by two rodent species in Brazilian Atlantic forest. Mammalia 68: 121-132.

Bleu J., Le Galliard J.F., Fitze P.S., Meylan S., Clobert J. \& Massot M. 2013. Reproductive allocation strategies: a long-term study on proximate factors and temporal adjustments in a viviparous lizard. Oecologia 171: 141-151

Bolker B.M., Brooks M.E., Clark C.J., Geange S.W., Poulsen J.R., Stevens M.H.H. \& White J.S.S. 2008. Generalized linear mixed models: a practical guide for ecology and evolution. Trends in Ecology and Evolution 24: 127-135.

Bonecker S.T., Portugal L.G., Costa-Neto S.F. \& Gentile R. 2009. A long term study of small mammal populations in a Brazilian agricultural landscape. Mammalian Biology 74: 467-477. 
BOONSTRA R. 2005. Equipped for life: the adaptive role of the stress axis in male mammals Journal of Mammalogy 86: 236-247.

Bozinovic F., RUIZ G. \& Rosenmann M. 2004. Energetics and torpor of a South American "living fossil", the microbiotheriid Dromiciops gliroides. Journal of Comparative Physiology B 174: 293-297.

Bozinovic F., RuIz G., CORTÉs A. \& Rosenmann M. 2005. Energetics, thermoregulation and torpor in the Chilean mouse-opossum Thylamys elegans (Didelphidae). Revista Chilena de Historia Natural 78: 199-206.

BRITO D., AstuA DE Moraes D., LEW D.\& SORIANo P. 2008. Monodelphis iheringi. In: IUCN 2010. IUCN Red List of Threatened Species. Version 2010.3.

BURNHAM K.P. \& ANDERSON D.R. 2002. Model selection and multimode inference: A practical Information- Theoretic Approach. 2nd edition. Springer, Colorado.

CÁCERES N.C. 2012. Os marsupiais do Brasil: biologia, ecologia e conservação. 2nd edition., Ed. UFMS, Campo Grande.

CACERES N.C., NÁPOl R.P. \& HANNiBAl W. 2011. Differential trapping success for small mammals using Pitfall and standard cage traps in a woodland savannah region of southwestern Brazil. Mammalia 75: 45-52.

CAdemartori C.V., FAbián M.E. \& ManeghetI J.O. 2005. Biologia reprodutiva de Delomys dorsalis (Hensel, 1872) - Rodentia, Sigmodontinae - em área de floresta ombrófila mista, Rio Grande do Sul, Brasil. Mastozoología Neotropical 12: 133-144.

CARMIGNOTtO A.P. \& PARDINI R. 2009. Monodelphis iheringi. In Mamíferos - Espécies ameaçadas do Estado de São Paulo. Ed. Percequillo A.R.

CASELLA J. \& CÁCERES N.C. 2006 Diet of four small mammal species from Atlantic forest patches in South Brazil. Neotropical Biology and Conservation 1: 5-11.

CERQueIRA R., Gentile R. \& Fernandez F.A.S. 1993. A five-year population study of an assemblage of small mammals in Southeastern Brazil. Mammalia 57: 507-517.

ClUtTON-BRock T.H., GUINNESS F.E. \& ALBON S.D. 1983. The costs of reproduction to red deer hinds. Journal of Animal Ecology 52: 367-383.

COLE L.C. 1954. The population consequences of life history phenomena. Quarterly Review of Biology 29: 103-137.

COLGAN W. \& CLARIDGE A.W. 2002. Mycorrhizal effectiveness of Rhizopogon spores recovered from fecal pellets of small forest-dwelling mammals. Mycology Research 106: 314-320.

Costa L.P., Leite Y.L.R., Mendes S.L. \& DitChfield A.D. 2005. Mammal Conservation in Brazil. Conservation Biology 19: 672-679.

COUTO D. \& TALAMONI S.A. 2005. Reproductive condition of Akodon montensis Thomas and Bolomys lasiurus (Lund) (Rodentia, Muridae) based on histological and histometric analyses of testes and external characteristics of gonads. Acta Zoologica 86: 111-118.

Cox R.M., Parker E.U., Cheney D.M., Liebl A.L., Martin L.B. \& Calsbeek R. 2010. Experimental evidence for physiological costs underlying the trade-off between reproduction and survival. Functional Ecology 24: 1262- 1269.

D’Andrea P.S., Gentile R., Majora L.S., Fernandes F.A., Coura R. \& Cerqueira R. 2007. Small mammal populations of an agroecosystem in the Atlantic Forest domain, southeastern Brazil. Brazilian Journal of Biology 67: 179-186. 
DíAz M. \& Alonso C.L. 2003. Wood mouse Apodemus sylvaticus winter food supply: density, condition, breeding, and parasites. Ecology 84: 2680-2691.

DíAz M.M. \& FLoRES D.A. 2008. Early reproduction onset in four species of Didelphimorphia in the Peruvian Amazonia. Mammalia 72: 126-130.

Dizney L., JONES P.D. \& RUEDAS L.A. 2008. Efficacy of Three Types of Live Traps Used for Surveying Small Mammals in the Pacific Northwest. Northwestern Naturalist 89:171-180.

Dray S., Pélissier R., Couteron P., fortin M.J., Legendre P., Peres-Neto P.R., Bellier E., Bivand, Blanchet F.G., Cáceres M. De, Dufour A.B., Heegaard E., Jombart T., Munoz F., Oksanen J., THIOULOUSE J. \& WAGNER H.H. 2012. Community ecology in the age of multivariate multiscale spatial analysis. Ecological Monographs 82: 257-275.

Feliciano B.R., Fernandez F.A.S., Freitas D. \& Figueiredo M.S.L. 2002. Population dynamics of small rodents in grassland between Atlantic Forest Fragments in southeastern Brazil. Mammalian Biology 67: 304-314.

FISHER D.O. \& BLOMBERG S. P. 2011 Correlates of rediscovery and the detectability of extinction in mammals. Proceedings of the Royal Society B-Biological Sciences 278: 1090-1097.

FLoWerdew J.R., HoRe R.F., Poulton S.M.C. \& SPARKS T.H. 2004. Live trapping to monitor small mammals in Britain. Journal of Comparative Physiology B 34: 31-50.

FonSECA G.A.B. \& KIERULFF M.C.M. 1989. Biology and natural history of Brazilian Atlantic Forest small mammals. Biological Science 34: 99-152.

GEISER F. \& BEUDINETTE R.V. 1987. Seasonality of torpor and thermoregulation in three dasyurid marsupials. Journal of Comparative Physiology B 157:335-344.

Gentile R., D'Andrea P.S., Cerqueira R. \& Maroja L.S. 2000. Population dynamics and reproduction of marsupials and rodents in a Brazilian rural area: a five-year study. Studies on neotropical fauna and environment 35:1-9.

GITTLEMAN J.L. \& THOMPSON S.D. 1988 Energy allocation in mammalian reproduction. American Zoology 28: 863-875.

GolDMAN B.D. 2001. Mammalian photoperiodic system: Formal properties and neuroendocrine mechanisms of photoperiodic time measurement. Journal of Biological Rhythms 16: 283-301

Gomez D., Sommaro L., Steinmann A., Chiappero M. \& Priotto J. 2011. Movement distances of two species of sympatric rodents in linear habitats of Central Argentine agro-ecosystems. Mammalian Biology 76:58-63.

Graipel M.E., Cherem J.J., Monteiro-Filho E.L.A. \& Glock L. 2006. Dinâmica populacional de marsupiais e roedores no parque municipal da Lagoa do Peri, Ilha de Santa Catarina, sul do Brasil. Mastozoología Neotropical 13:31-49.

HALLE S. 2000. Ecological relevance of daily activity patterns. Pp 67-90 in Activity patterns in small mammals: an ecological approach. Eds: Halle S. \& Stenseth N.C. Springer-Verlag, Berlin, Heidelberg.

HARDY I.C.W. 2002. Sex ratio: Concepts and research methods. Cambridge University Press. Cambridge.

HARSHMAN L.G. \& ZeRA A.J. 2007. The cost of reproduction: the devil in the details. Trends in Ecology and Evolution 22: 80-86.

HUGGINS R.M. 1991. Some practical aspects of a conditional likelihood approach to capture experiments. Biometrics 47: 725-732. 
HUNTER JR M.L. \& GIBBS J. 2007. Fundamentals of Conservation Biology. 3rd edition. Blackwell Publishing, Oxford.

ISAAC J.L. \& JOHNSON C.N. 2005. Terminal reproductive effort in a marsupial. Biology Letters 1: 271275.

Kajin M., Cerqueira R., Vieira M.V. \& Gentile R. 2008 Nine-year demography of the black-eared opossum Didelphis aurita (Didelphimorphia: Didelphidae) using life tables. Revista Brasileira de Zoologia 25: 206-213

KARL T.R. \& TRenberTH K.E. 2003. Modern Global Climate Change. Science 302: 2003.

KENDALL W.L., NiCHOLS J.D. \& HINES J.E. 1997.Estimating temporary emigration using capturerecapture data with Pollocks robust design. Ecology 78: 563-578.

KoIVUla M., Koskela E., Mappes T. \& OKSANen T.A. 2003. Cost of reproduction in the wild: manipulation of reproductive effort in the bank vole. Ecology 84:398-405.

KraAiJeVeld K., KRAAIJeVeld-Smit F.J.L., Adcock G.J. 2003. Does female mortality drive male semelparity in dasyurid marsupials? Proceedings of the Royal Society B-Biological Sciences 270: S251-S253.

KREBS CJ. 2002. Beyond population regulation and limitation. Wildlife Research 29: 1-10.

LAMBeRT T., MAlColm J.R. \& Zimmerman B.L. 2006 Amazonian small mammal abundances in relation to habitat structure and resource abundance. Journal of Mammalogy 87: 766-776.

Lebreton J.D., Burnham K.P., Clobert J. \& Anderson D.R. 1992. Modeling survival and testing biological hypotheses using marked animals-a unified approach with case-studies. Ecological Monographs 62: 67-118.

LeINeR N.O., Setz E.Z.F. \& SILVA W.R. 2008. Semelparity and factors affecting the reproductive activity of the brazilian slender opossum (Marmosops paulensis) in southeastern Brazil. Journal of Mammalogy 89: 153-158.

LEINER N.O. \& SILVA W.R. 2007. Seasonal variation in the diet of the brazilian slender opossum (Marmosops paulensis) in a montane atlantic forest area, southeastern brazil. Journal of Mammalogy 88: 158-164.

LEVINS S.A. 2009. The Princeton Guide to Ecology. Princeton University Press, New Jersey.

LIMA M., JULLIARD R., STENSETH N.C. \& JAKSIC F.M. 2001a. Demographic dynamics of a neotropical small rodent (Phyllotis darwini): feedback structure, predation and climatic factors. Journal of Animal Ecology 70: 761-775

LIMA M., STENSETH N.C., Yoccoz N.G. \& JAKSIC F.M. 2001b. Demography and population dynamics of the mouse opossum (Thylamys elegans) in a semi-arid Chile: seasonality, feedback structure and climate. Proceedings of the Royal Society of London 268: 2053-2064.

LiRa P.K., Fernandez F.A.S., CARlos H.A.S. \& CURzio P.L. 2007. Use of a fragmented landscape by three species of opossums in southeastern Brazil. Journal of Tropical Ecology 23: 427-435.

LORINI M.L., OliveIRA J.A. \& PERSSON V.G. 1994. Annual age structure and reproductive patterns in Marmosa incana (Lund, 1841) (Didelphidae, Marsupialia). Z. Säugetierkunde 59: 65-73.

LUIS A.D., DouglasS R.J., MILLS J.N. \& BJøRNSTAD O.N. 2010. The effect of seasonality, density and climate on the population dynamics of Montana deer mice, important reservoir hosts for Sin Nombre hantavirus. Journal of Animal Ecology 79: 462-470.

LYRA-JoRge M.C. \& PIVELLO V.R. 2001. Combining live trap and Pitfall to survey terrestrial small mammals in savanna and forest habitats in Brazil. Mammalia 65: 524-530. 
Macedo J., LoRetto D., Vieira M.V. \& Cerqueira R. 2006. Classes de desenvolvimento em marsupiais: um método para animais vivos. Mastozoología Neotropical 13: 133-136.

MAgurRAn A.E. \& McGiLl B.J. 2010. Biological Diversity: Frontiers in Measurement and Assessment: Frontiers in Measurement and Assessment. Oxford University Press, Oxford.

MANGAN S.A. \& AdLeR G.H. 2000. Consumption of arbuscular mycorrhizal fungi by terrestrial and arboreal small mammals in a Panamanian cloud forest. Journal of Mammalogy 81: 563-570.

MARTINS E.G., Bonato V., DA-SILVA C.Q. \& ReIS S.F. 2006b. Seasonality in reproduction, age structure and density of the gracile mouse opossum Gracilinanus microtarsus (Marsupilais: Didelphidae) in a Brazilian Cerrado. Journal of Tropical Biology 22: 461-468.

Martins E.G., Bonato V., DA-Silva C.Q. \& Reis S.F. 2006. Partial semelparity in the neotropical didelphid marsupial Gracilinanus microtarsus. Journal of Mammalogy 87: 915-920.

MCALLAN B.M. 2003. Timing of reproduction in carnivorous marsupials. Pp: 147-168. In: Predators with Pouches: the Biology of Carnivorous Marsupials. Eds: Jones M., Dickman C. \& Archer M. SCIRO, Melbourne.

McAllan B.M., Dickman C.R. \& Crowther M.S. 2006. Photoperiod as a reproductive cue in the marsupial genus Antechinus:ecological and evolutionary consequences. Biological Journal of the Linnean Society 87: 365-379.

MERRITT J.F. 2010. The Biology of small mammals. The Johns Hopkins University Press, Baltimore.

Metzger J.P., Alves L.F., Goulart W., Teixeira A.M.G., Simões S.J.C. \& Catharino E.L. 2006. An important biological area, but still poorly known: the Morro Grande Forest Reserve. Biota Neotropica 6.

Miller J.R., Groom M., Hess G.R., Steelman T., Stokes D.L., Thompson J., Bowman T., Fricke L., King B. \& MARQUARDT R. 2009. Biodiversity Conservation in Local Planning. Conservation Biology 23: 53-63.

Moyes K., Coulson T., Morgan B.J.T., Donald A., MoRris S.J. \& Clutton-Brock T.H. 2006. Cumulative reproduction and survival costs in female red deer. OIKOS 115: 241-252.

Myers N., Mittermayer R.A., Mittermayer C.G., FonseCA G.A.B. \& Kent J. 2000. Biodiversity hotspots for conservation priorities. Nature 403: 853-858.

NAYLOR R., RICHARDSON S. J., MCALLAN B.M. 2008. Boom and bust: a review of the physiology of the marsupial genus Antechinus. Journal of Comparative Physiology B-Biochemical Systemic and Environmental Physiology 178: 545-562.

NICOLAS V. \& COLYN M. 2006. Relative efficiency of three types of small mammal traps in an African rainforest. Belgian Journal of Zoology 136: 107-111.

NoWAK R.M. 1991. Walker's Mammals of the World. Johns Hopkins University Press, Maryland.

OACKWOOD M., BRADLEY A.J. \& COCKBURN A. 2001. Semelparity in a large marsupial. Proceedings of the Royal Society of London B 268: 407-411

Oksanen J., Blanchet F.G., Kindt R., Legendre P., Minchin P.R., O'HaRA R. B., Simpson G.L., Solymos P., HenRy M., Stevens H. \& WAGNeR H. 2013. vegan: Community Ecology Package. R package version 2.0-7. http://CRAN.R-project.org/package=vegan

OLI MK \& DOBSON FS. 2003 The relative importance of life-history variables to population growth rate in mammals: Cole's prediction revisited. American Naturalist 161: 422-440.

Paglia A.P., Fonseca G.A.B., Rylands A.B., Herrmann G., Aguiar L.M.S., Chiarello A.G., Leite Y.L.R., Costa L.P., Siciliano S., Kierulff M.C.M., Mendes S.L., Tavares V. da C., MitTermeier R.A. \& PATTON J.L. 2012. Lista Anotada dos Mamíferos do Brasil / Annotated Checklist of Brazilian 
Mammals. 2a Edição / 2nd Edition. Occasional Papers in Conservation Biology, No. 6. Conservation International, Arlington, VA.

PAISE G. \& VIEIRA E.M. 2006. Daily activity of a neotropical rodent (Oxymycterus nasutus): seasonal changes and influence of environmental factors. Journal of Mammalogy 87: 733-739.

PARDINI R. 2004. Effects of forest fragmentation on small mammals in an Atlantic Forest landscape. Biodiversity and Conservation 13: 2567-2586.

PARDINI R. \& UMETSU F. 2006. Non-volant small mammals from the Morro Grande Forest Reserve distribution of species and diversity in an Atlantic Forest area. Biota Neotropica 6.

PASSAMANI M. 2000. Análise da comunidade de marsupiais em Mata Atlântica de Santa Teresa, Espírito Santo. Boletim Museu Biolologia Mello Leitão 1/12: 215-228.

PeIG J. \& GReEn A.J. 2010. The paradigm of body condition: a critical reappraisal of current methods based on mass and length. Functional Ecology 24: 1323-1332.

Percequillo A.R., WeKsler M. \& Costa L.P. 2011. A new genus and species of rodent from the Brazilian Atlantic Forest (Rodentia: Cricetidae: Sigmodontinae: Oryzomyini), with comments on oryzomyine biogeography. Zoological Journal of the Linnean Society161: 357-390.

Pimentel D.S. \& Tabarelli M. 2004. Seed dispersal of the palm Attalea oleifera in a remnant of the Brazilian Atlantic Forest. Biotropica 36: 74-84.

PINOTTI B.T., NAXARA L. \& PARDINI, R. 2011. Diet and food selection of small mammals in old growth Atlantic Forest of South-eastern Brazil. Studies on Neotropical Fauna and Environment 46: 19.

PINOTTI B. 2010. Pequenos mamíferos terrestres e a regeneração da Mata Atlântica: influência da estrutura do habitat e da disponibilidade de alimento na recuperação da fauna. MSc Thesis. University of São Paulo, São Paulo, Brazil.

Pinto L.P., Bedê L., PAese A., Fonseca M., PAglia A. \& LAMs I. 2006. Mata Atlântica brasileira: os desafios para a conservação da biodiversidade de um hotspot mundial. Pp 91-118 In Rocha C.E.D., Bergallo H.G., Sluys M.V. \& Alves M.A.S. (eds). Biologia da Conservação: Essências . RiMa Editora, São Carlos.

PIRES A.S. \& F.A.S. FERNANDEZ. 1999. Use of space by the marsupial Micoureus demerarae in small Atlantic forest fragments in south-eastern Brazil. Journal of Tropical Ecology 15: 279-290.

PoLLOCK K.H. 1982. A capture-recapture design robust to unequal probability of capture. Journal of Wildlife Management 46: 752-757.

PRADEL R. 1996. Utilization of capture-mark-recapture for the study of recruitment and population growth rate. Biometrics 52: 703-709.

PreVedello J.A., Dickman C.R., Vieira M.V. \& Vieira E.M. 2013. Population responses of small mammals to food supply and predators: a global meta-analysis. Journal of Animal Ecology. in press.

PÜtTKeR T., MeYer-LUCht Y. \& SOMmer S. 2006. Movement distances of five rodent and two marsupial species in forest fragments of the coastal atlantic rainforest, Brazil. Biotropica 22: 131-139.

Quental T.B., Fernandez F.A.S., Dias A.T.C. \& Rocha F.S. 2001. Population dynamics of the marsupial Micoureus demerarae in the small fragments of Atlantic Coastal Forest in Brazil. Journal of Tropical Ecology 17: 339-352. 
R Development Core Team. 2011. R: A language and environment for statistical computing. $R$ Foundation for Statistical Computing, Vienna, Austria. ISBN 3-900051-07-0, URL http://www.R-project.org/.

ReIS N.R., PeRACCHI A.L., Pedro W.A. \& LIMA I.P. 2011. Mamíferos do Brasil. 2a Ed. Londrina.

RIBEIRO-JÚNIOR M.A., RosSI R.V., MIRANDA C.L. \& ÁvILA-PIRES T.C.S. 2011. Influence of Pitfall trap size and design on herpetofauna and small mammal studies in a Neotropical Forest. Zoologia 28: 80-91.

Rivalan P., Prevot-Julliard A.C., Choquet R., Pradel R., Jacquemin B. \& Girondot M. 2005 Trade-off between current reproductive effort and delay to next reproduction in the leatherback sea turtle. Oecologia 145: 564-574.

SÁnCheZ-CoRdero V. \& MARTINEZ-Gallardo R. 1998. Postdispersal fruit and seed removal by forest dwelling rodents in a lowland rainforest in México. Journal of Tropical Ecology 14:139-151.

SANTOS-FILHO M., SILVA D.J. \& SANAIOTTI T.M. 2006. Efficiency of four Trap Types in Sampling Small Mammals in Forest Fragments, Mato Grosso, Brazil. Mastozoología Neotropical 13: 217-225.

SPEAKMAN J.R. 2008. The physiological costs of reproduction in small mammals. Philosophical Transactions of the Royal Society B 363: 375-398.

StANLEY T.R. \& BURNHAM K.P. 1999. A closure test for time-specific capture-recapture data. Environmental and Ecological Statistics 6: 197-209

SteARNS S.C. 1992. The evolution of life histories.1992. Oxford University Press, Oxford.

TALAMONI S.A., COUto D., CORDEIRo D.A. \& Diniz F.M. 2008. Diet of some species of Neotropical small mammals. Mammalian Biology 73: 337-341.

Thibault K.M., Morgan ERneSt S.K., White E.P., Brown J.H. \& Goheen J.R.2010.Long-term insights into the influence of precipitation on community dynamics in desert rodents. Journal of Mammalogy 91: 787-797.

TORRE I., GUIXÉ D. \& SORT F. 2010. Comparing Three Live Trapping Methods for Small Mammal Sampling in Cultivated Areas of Ne Spain. Hystrix 21: 147-155.

TRIBE C.J. 1990.Dental age classes in Marmosa incana and other didelphoids. Journal of Mammalogy 71: 566-569.

TYNDALE-BISCOE H. 2005. Life of Marsupials. CSIRO Publishing. Collingwood, Australia.

UMETSU F. \& PARDINI R. 2007. Small mammals in a mosaic of forest remnants and anthropogenic habitats- evaluating matrix quality in an Atlantic forest landscape. Landscape Ecology 22: 517-530.

UMETSU F., NAXARA L. \& PARDINI R. 2006. Evaluating the efficiency of Pitfall traps for sampling small mammals in the Neotropics. Journal of Mammalogy 87: 757-765.

VICKERY W.L. \& BIDER J.R. 1981. The Influence of Weather on Rodent Activity. Journal of Mammalogy 62: 140-145.

VIEIRA E.M., PIZO M.A. \& IZAR P. 2003b. Fruit and seed exploitation by small rodents of the Brazilian Atlantic Forest. Mammalia 67: 533-539.

VIEIRA E.M., PAISE G. \& MACHADO P.H.D. 2006. Feeding of small rodents on seeds and fruits: a comparative analysis of three species of rodents of the Araucaria forest, southern Brazil. Acta Theriologica 51: 311-318.

Vieira E.M., Baumgarten L.C., Paise G. \& Becker R.G. 2010. Seasonal patterns and influence of temperature on the daily activity of the diurnal neotropical rodent Necromys lasiurus. Canadian Journal Zoology 88: 259-265. 
Voss R.S., LUnde D.P. \& SIMmons N.B. 2001. The Mammals of Paracou, French Guiana: A Neotropical Lowland Rainforest Fauna- Part 2. Nonvolant Species. Bulletin of the American Museum of Natural History 263:1-236.

WHITE G.C. \& BURNHAM K.P.1999. Program MARK: survival estimation from populations of marked animals. Bird Study 46: 120-139.

White G.C., Anderson D.R., Burnham K.P. \& OtIS D.L. 1982. Capture-Recapture and removal methods for sampling closed populations. Los Alamos National Laboratory.

WILLIAMS B.K., NiCHOLS J.D. \& CONROY M.J. 2002. Analysis and management of animal populations: modeling, estimation, and decision making. Academic Press, London.

Zuur A. F., Ieno E.N., Walker N.J., Saveliev A.A. \& SMith G.M. 2009. Mixed Effects Models and extensions with R. Springer, New York. 